Portland State University

PDXScholar

\title{
The Resurrection of a River: The Umatilla and its Salmon
}

Christopher Ward Shelley

Portland State University

Follow this and additional works at: https://pdxscholar.library.pdx.edu/open_access_etds

Part of the Natural Resources and Conservation Commons, and the United States History Commons Let us know how access to this document benefits you.

\section{Recommended Citation}

Shelley, Christopher Ward, "The Resurrection of a River: The Umatilla and its Salmon" (2002).

Dissertations and Theses. Paper 3971.

https://doi.org/10.15760/etd.5869

This Thesis is brought to you for free and open access. It has been accepted for inclusion in Dissertations and Theses by an authorized administrator of PDXScholar. Please contact us if we can make this document more accessible: pdxscholar@pdx.edu. 


\section{THESIS APPROVAL}

The abstract and thesis of Christopher Ward Shelley for the Master of Arts in

History were presented March 15, 2002, and accepted by the thesis committee and department.

COMMITTEE APPROVALS:

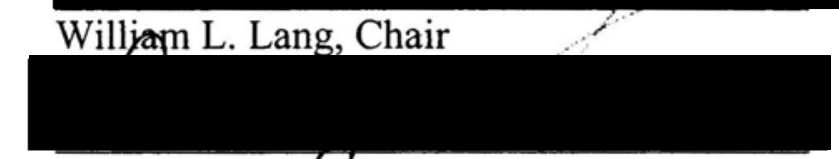

David A. John\$on

DEPARTMENT APPROVAL:
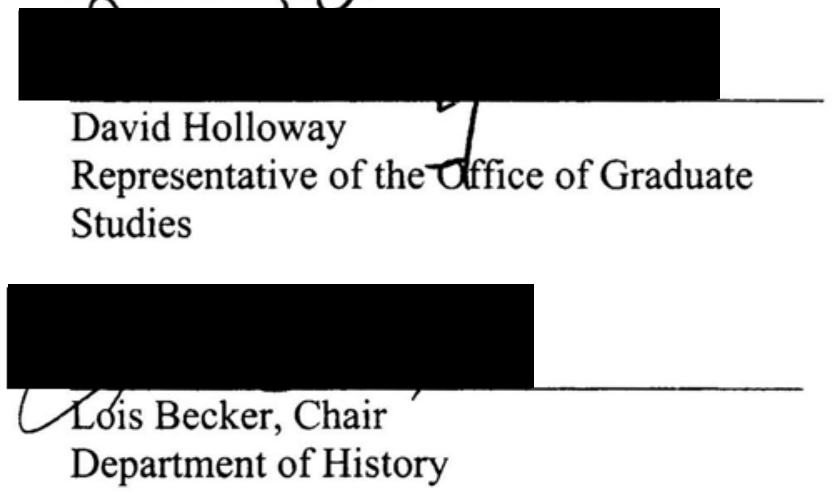


\begin{abstract}
An abstract of the thesis of Christopher Ward Shelley for the Master of Arts in History presented March 15, 2002
\end{abstract}

Title: The Resurrection of a River: The Umatilla and its Salmon.

Until the 1990s, salmon had been extinct from the Umatilla River for over 70 years. The struggle to bring salmon back to this river is a compelling story that exemplifies some of the new relationships in Columbia River Basin salmon management.

The Umatilla River and the disappearance of its salmon was a local issue. Irrigation interests had used the river so thoroughly it ceased to flow during the late summer and fall months—-precisely when salmon needed it for migration. The Confederated Tribes of the Umatilla Indian Reservation saw decided that they would change that: they would figure out a way to put both salmon and water back into the river.

This thesis examines this process. First, it contextualizes the Umatilla River within the Columbia River Basin and Columbia Basin salmon management, and shows how a local salmon issue became a regional salmon issue. It then 
discusses the triangle of relationships that Indians, salmon, and hatcheries have come to form. Chapter III discusses the formation of the unique Umatilla Fish Restoration Program, which reintroduced fish into the river, and was paid for by the Bonneville Power Administration (BPA), as per the Northwest Power Act. Key elements within BPA's Fish and Wildlife Division resisted complying with the directives of the Northwest Power Planning Council to pay for the Program, setting the Program back years. I argue that this comes from two clashing ways of seeing the River: "cost-benefit analysis" versus "least cost."

Chapter IV looks at the new partnerships formed in the Umatilla River Basin by the Tribes and irrigation districts in order to encourage the U.S. Bureau of Reclamation to construct a water delivery system that would satisfy irrigators while allowing most of the Umatilla to flow freely.

The last Chapter suggests that these new and somewhat ironic partnerships between federal and state governments, private irrigators and landowners, nongovernmental organizations, and Indian tribes are key to restoring ecosystems in the Columbia River Basin. It further argues that without tribal nations playing an active role and exerting their treaty rights, restoring rivers like the Umatilla is impossible. 
THE RESURRECTION OF A RIVER:

THE UMATILLA AND ITS SALMON

by

CHRISTOPHER WARD SHELLEY

A thesis submitted in partial fulfillment of the requirements for the degree of

\section{MASTER OF ARTS}

in

HISTORY

Portland State University

2002 


\section{DEDICATION}

For Gia,

Whose strength and compassion are beyond measure,

and because "Job ain't in it." 


\section{ACKNOWLEDGMENTS}

My debts are great. Many people have been very patient with me as I wound my way through school and worked on this thesis. First, my family, Gia, Alwynn, and Cian, who have paid a high price for the glacial pace of this project. And to the support and generosity of Marj and Jerry Shelley, and Gail and Fred Accuardi, I owe the greatest thanks.

My intellectual debts to David Johnson, Tom Morris, and especially Bill Lang are incalculable. Bill has helped me shape not only this thesis and many of the ideas in it, but my ideas as a scholar. Without his mentorship, this work would be so much recycling. And no graduate student at Portland State University's history Department would ever make it out alive were it not for Diane Gould.

Donald Sampson showed me some of what happens "between the lines" of the salmon crisis. Gary James at the Department of Natural Resources for the Confederated Tribes of the Umatilla Indian Reservation allowed me access to thousands of documents.

Finally, this work is profoundly informed by my association with Salmon Corps: John Fred, Roland Kalama Jr., Modesta Minthorn, and Scott Welch especially have introduced me to some of the richest parts of salmon country. In particular I wish to thank Chuck Sams, who fierce generosity has allowed me a glimpse of the Wakanish as they make their way up the Big River 


\section{TABLE OF CONTENTS}

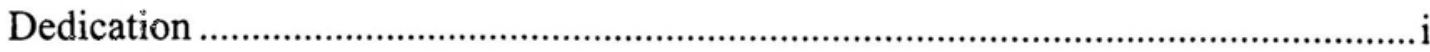

Acknowledgments ...............................................................................................

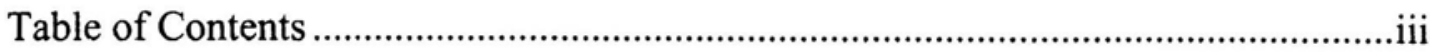

CHAPTER I - Introduction: The Spiritual Death of a River....................................... 1

Drying the Umatilla .........................................................................................

The Northwest Power Act .................................................................................. 13

The Umatilla River and the Northwest Salmon Crisis............................................ 19

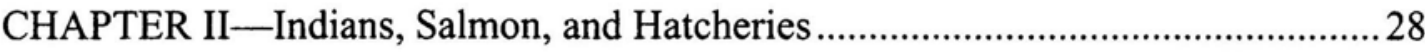

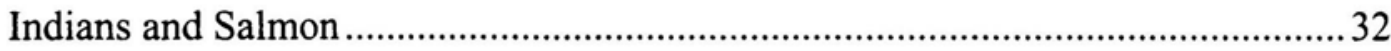

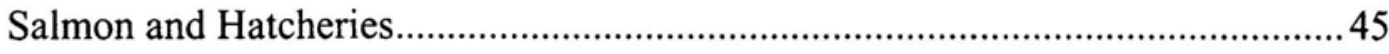

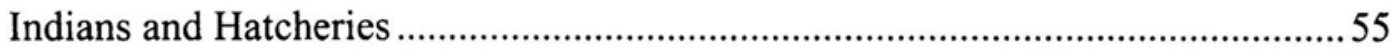

CHAPTER III-The Semantics of Conservation: Implementing the Umatilla River

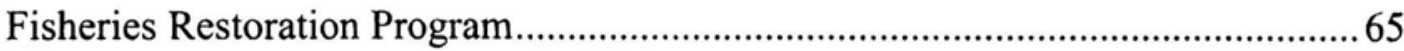

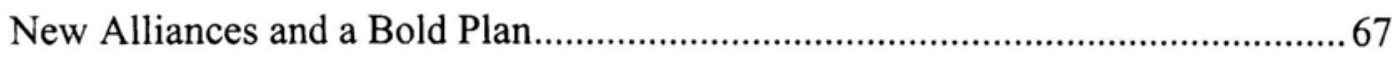

Cost-Benefit versus Cost Effective ……………………....................................... 73

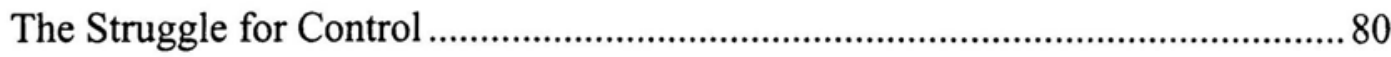

CHAPTER IV-Re-Watering the Umatilla: The Umatilla Basin Project ..................96

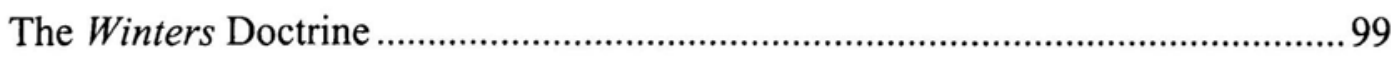

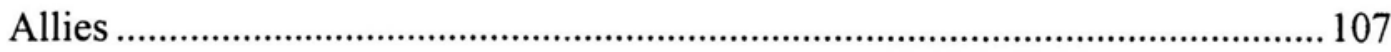

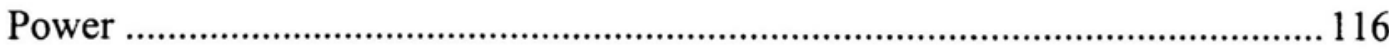

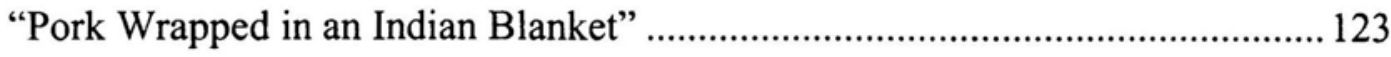

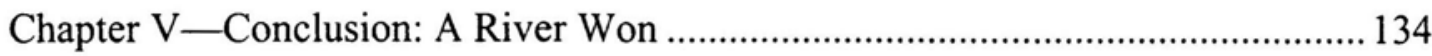

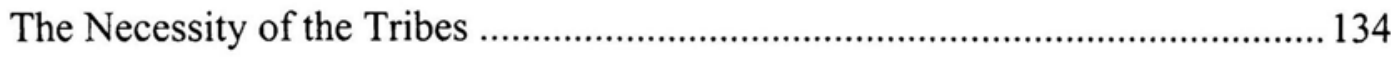

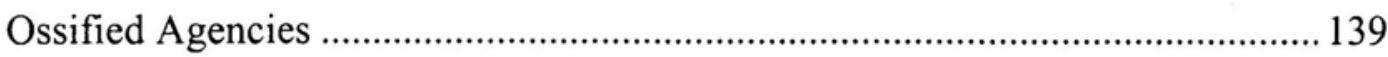

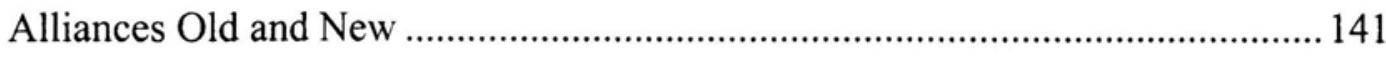

Terminal References.................................................... 162 


\section{CHAPTER I-INTROduction: THE SPIRITUAL DEATH OF A RIVER}

The bleaching of algae once waving green underwater to white; river stones once cool now hot to the touch and dry; spider webs stretched where there had been salmon eggs; snakes where there had been trout-it was as though the river had been abandoned.

$$
\text { -Barry Lopez }{ }^{1}
$$

$m m m$

IN THE NORTHEAST OF OREGON, rivers flow radially from two great mountain ranges, the Blues and the Wallowas, which rise up out of the semi-arid Columbia Plateau. Like crooked spokes, five salmon-bearing streams, the Imnaha, the Grande Ronde, the Tucannon, the Walla Walla, and the Umatilla, wind out of the mountains into the great counter-clockwise half-wheel of the Snake and the Columbia Rivers. The western of these ranges, the Blue Mountains, shed water north and west into many small creeks that flow through dry foothills or wheat-covered plains and gather into the Umatilla River. Through the heart of the Umatilla Indian Reservation, then through the City of Pendleton, and bending north, the Umatilla enters the Columbia River just downstream from McNary Dam.

Or at least, the Umatilla enters the Columbia when it contains water. During the late summer and early fall months the Umatilla is sucked dry along its last three miles by the relentless thirst of irrigated farms. By the 1920s, the practice of irrigation on the Umatilla River and its major tributaries diverted enough water for a 
long enough period at crucial times during the year to exterminate the native chinook and coho runs that had migrated to the river for eons. ${ }^{2}$

Salmon and steelhead represent a spiritual, cultural, and economic resource for the Cayuse, Walla Walla, and Umatilla Indians, the three tribes that comprise the Confederated Tribes of the Umatilla Indian Reservation (CTUIR). ${ }^{3}$ The historic reliance of Mid-Columbia River Indians on salmon is well documented. ${ }^{4}$ In the Treaties of 1855 they ceded title to millions of square miles of land and reserved the right to fish at "all the usual and accustomed stations." Numerous court decisions since the turn of the century have consistently affirmed this reserved right, but over the last half of this century, many of the accustomed fishing places along with the fish have disappeared, thus eroding the Indians' rights. ${ }^{6}$ By 1974, when Judge George Boldt in United States v. Washington recognized the rights of all signatory tribes to the 1855 treaties with Washington Territorial Governor Isaac I. Stevens by guaranteeing them one-half the catch of all available salmon, their right to fish had, in fact, already been severely restricted by developments on the Columbia River and its tributary basins. ${ }^{7}$ Irrigation diversions that began to water farms at the turn of the century dried up rivers on the plateau and killed fish. Federal irrigation projects on the Columbia's tributaries such as the Yakima and Umatilla from 1905 into the 1920s killed fish more efficiently and prevented them from reaching traditional fishing grounds on and near the reservations. Dam building on the Columbia River mainstem from the 1930s into the 1950s had obliterated many traditional fisheries, including Celilo Falls. While the government compensated the Tribes monetarily for 
some of these losses, the radical alterations to the Columbia River Basin environment shattered the cultural center of a people. ${ }^{8}$

By the 1970s, the Confederated Tribes had resolved that it would no longer live with a dead Umatilla River. Because of legal developments, changes in public opinion, and the shifting of alliances among wildlife management agencies in the Columbia River Basin, the Tribes saw a window of opportunity to bring about change. In 1980, capitalizing on a growing concern in the region over declining salmon numbers, the Boldt decision, and the passage of the Northwest Power Act, the Tribes advanced a plan to revive the Umatilla as a viable salmon stream.

The purpose here is to document the restoration of salmon to the Umatilla River, a medium-sized stream in Eastern Oregon. The story of the Umatilla River salmon is deceptively simple - a river's salmon were extirpated, then years later were restored. Yet it cannot be told without understanding the complex connections between the Columbia and Umatilla Rivers. Neither can the story of Columbia River salmon be separated from the history of Columbia River Indians, who have relied on salmon for hundreds of generations and were the major actors in resurrecting the spirit of their river. And the restoration of these remarkable fish cannot be told without examining the political and managerial power structure that administers salmon restoration in the Columbia River Basin.

To extract the meaning of this restoration out of the complex nature of the Northwest salmon crisis, we must grapple with three major issues. First is the threesided relationship of Columbia River Indians, Columbia River salmon, and salmon 
hatcheries. The relationship of Indians to salmon is ancient. It is at once spiritual and economic and legal, and it ties the Indians inexorably to the rivers of the Columbia Basin. The relationship of hatcheries to salmon is much younger, just over one hundred years old. Historically, fish managers used hatcheries on a massive scale, without hard scientific data to understand their effects. More recently scientists have shown that the abuse of hatcheries has done great damage to wild salmon populations. "Salmon culture" (as the artificial propagation of salmon was called early in the century) is no longer the be-all and end-all of anadromous fish management. ${ }^{9}$ This has led to a vigorous debate about the place of hatcheries, if any, in salmon recovery. Similarly, the newer relationship of Indians to hatcheries has been quite controversial. To help bring back salmon, the signatory tribes of the 1855 treaties in the Columbia Basin have employed the idea of using small-scale hatcheries to augment wild fish. The Tribes' use of hatcheries has upset some environmental groups that advocate strictly for wild fish. It has also upset state fish and wildlife organizations that have had a monopoly on hatchery production for decades. The failure of modern fishery managers to include Indians in discussions about hatcheries and the unwillingness of the states to consult with the Tribes on hatchery policies, contrary to the implications of the Boldt decision, has caused the Indians to perceive the actions of governmental agencies as a betrayal of their treaty rights. ${ }^{10}$

The second issue is the "nuts and bolts" of salmon recovery in the Umatilla Basin. The Umatilla Program was just one of an array of projects aimed at reversing 
the decline of salmon and steelhead in the Columbia Basin. The process of planning, funding, and constructing the hatchery system to restore salmon to the Umatilla illustrates many of the problems of basin-wide salmon recovery. Here, the fundamental problem is the conflict between the "new" way of running the Columbia River system represented by the statutory power of the Northwest Power Planning Council and its focus on biological imperatives, and the "old" way of running the river exemplified by the Army Corps of Engineers and the Bonneville Power Administration. This "old" way of running the river is based on economics over ecology, and it is founded on the classic paradigm of river development that has prevailed on the Columbia since the Second World War: the cost-benefit analysis. ${ }^{11}$ Cost-benefit analysis is a legitimate tool for judging the comparative worth of projects that develop infrastructure and whether they are economically justified. Using this model, a municipality might estimate the value of a bridge by judging the cost of building that bridge against the economic benefits that the society can reasonably expect from the bridge's construction. But cost-benefit analysis produces a truncated understanding of projects with biological goals. The Northwest Power Act charges the Northwest Power Planning Council (NPPC) and the bureaucracies that run the hydroelectric operations with restoring salmon by the most cost effective means possible. Restoration is an imperative, not an option. But the "old" way of managing the Columbia Basin dies hard. It has proved difficult for engineers and bureaucrats to overcome the older imperatives of economic and engineering efficiencies. Cost-benefit analysis has become so ingrained in the language of river 
managers that, despite the biological requirements of salmon and steelhead in the basin, it is still difficult for the agencies in charge of the river and salmon restoration to move beyond it. ${ }^{12}$

Third, restoration could not have happened without a fundamental change to the Umatilla itself. The parched river needed sufficient water. To this end, the Tribes cultivated support from local groups in the Umatilla Basin to lobby Congress for a \$46 million water exchange project, one that would swap Columbia River water to the irrigators for Umatilla River water. This statutory appropriation of funds was successful and applauded locally, but regionally it had to overcome stiff resistance. River interests from outside the Umatilla Basin, such as utilities that were direct customers of BPA, fought all aspects of the fisheries restoration program and the Umatilla Basin Project. As electricity ratepayers, and therefore indirectly paying for Bonneville's fish and wildlife expenditures, these utilities argued against restoring both salmon and water to the Umatilla River. Nevertheless, in 1988, partially because of the influence of Oregon's senior senator, Mark Hatfiled, Congress passed the Umatilla Basin Act to re-water the Umatilla.

Because of the intractability of water politics in eastern Oregon, the tactics of the Tribes to bring water back to the Umatilla did not involve litigation and an assertion of water rights (as they did with the fisheries program by asserting fishing rights). Therefore, the Umatilla Basin Project changed none of the traditional relationships of irrigation and federal water policies. While many argue there must be a fundamental shift in the management of electricity generation and irrigation 
water disbursement in the Columbia Basin toward ecological harmony and balance, this project would not address that. No governmental agencies, state or federal, would radically alter the way water was distributed in the Umatilla Basin. These agencies, irrigation districts, and Indian Tribes could avoid the controversy of reallocating the Umatilla River if tens of millions of dollars from outside the region could reallocate part of the Columbia. Rather than revolutionize the way water is allocated in arid eastern Oregon, the Project relied on the tried-and-true method of developing the American West: the appropriation of funds from the federal government.

Before we examine salmon restoration on the Umatilla River, this chapter shall set the backdrop by looking at three other topics that are critical to understanding this narrative. First is the nature of the Umatilla River and the reasons for salmon decline in the Umatilla Basin. Second are the physical and political effects of the mainstem dams. Third is the creation of the Northwest Power Planning Council's Columbia River Basin Fish and Wildlife Program.

$$
\text { t }
$$

\section{Drying the Umatilla}

The Umatilla's headwaters in the Blue Mountains appear pristine, the quintessential mountain stream: a perfect habitat for anadromous fish and the spawning ground of the few wild steelhead still in the basin. The North and South Forks flow through old-growth forest and converge just east of the Umatilla Indian 
Reservation. The river runs down into the foothills, collecting the side creeks flowing from canyons. Ponderosa pine and Douglas fir stand on the steep grades of the canyon walls. On the cobbled riverbed, where cottonwoods and willows line each bank, there are occasionally downed trees bolted to the river-bottom by thick cables: the product of stream restoration efforts. Cattle graze in the riverbottom upstream and in the side canyons of these hills, and the green and brown algae along the river bottom are a result of their manure. White, dried pond scum bakes along the stones where the riverbed is exposed. Already, miles upstream of the major irrigation diversions the river is somewhat degraded.

Downstream, the steep foothills diminish. The river's canyon gradually becomes a valley. The mixed evergreens thin to a few pines. The scent changes from pungent coniferous forest to that of ripening wheat fields after a thunderstorm. Rolling hills of golden-brown grasslands, with no trees at all, then almost no hills, then merely a depression, a shallow fold in the land where the only green is the cottonwood belt of the river. The Umatilla's valley becomes a slight dip where it flows in broad turns through lands more flat, into the wheat fields.

The river leaves the Reservation and after a few miles it enters downtown Pendleton, flowing just north of the center of town, where the river begins to sicken. Under a bridge, more clots of green algae cling to rocks and trail behind them like green beards. Brown algae blooms in profusion along the bottom where the current is slack. The river gradually slices through to the southwest of town, and runs down, under the Interstate, along crumbling basalt bluffs and through farmer's fields. It is in 
these last 35 or so miles between Pendleton and the Columbia that irrigation takes its great toll. A small diversion dam shunts water into a ditch away from the river. The ditch goes under the road, then along the road, then above the road. In a barely descending traverse of the hillside, flowing downhill far less rapidly than the river or the road, the ditch twists and curves, following the contour of the hill off into the sagebrush, to some faraway wheat or alfalfa field. Below the road is a short diversion, maybe Echo Dam or Maxwell Dam, shiny with the newly built facility for passing salmon upstream, or collecting them for truck transport if there is no stream to pass up into. Judging the entire river by looking at this reach, from the town of Echo to the city of Umatilla, the Umatilla would hardly be one's first choice to reestablish salmon.

The river continues to degrade the nearer it gets to the Columbia. Three miles from the confluence with the Columbia is the largest diversion, Threemile Dam. It is a slightly curved concrete structure approximately seventy-five yards long and rising twenty feet above the level of the dying river. Its downstream face is sculpted into scalloped concavities, where water seeps through small cracks. In the perpetual shade of a northern exposure mosses and slimy algae grow. The old, decrepit fish ladder on the west bank has been augmented by a brand new ladder and holding facility built into the dam on the east bank. A pond at the foot of the ladder holds a dozen enormous carp, demonstrating that this is a warm-water habitat, not the coldwater home of salmon. A trickle finds its way out of the pond, down a parched basalt bed, across the foot of the dam, then downstream. What is left of the Umatilla is 
maybe six inches deep. Despite the shiny newness of the fish ladder, it is clear from this tiny trickle of water on a glaring mid-July afternoon (not even the "dry season" of August) that the river dies before it reaches the Columbia. Decades of overappropriation, withdrawing more water than the river's ecosystem could sustain, have crippled the lower reaches of the Umatilla.

To the early settlers of eastern Oregon, the huge, dry plains of the Columbia Plateau were meant to be grazed and farmed. But in the American West farmland is seldom any good without access to flowing water. To simplify the complex Plateau sage-and-juniper ecosystem into a monoculture and convert the land into wealth, farmers began to draw on the rivers of region to water their crops. This was a huge undertaking. It was not simply a matter of cutting a ditch or two into the river and using the water. Most of the converted plains lay far from any stream. It would take a great feat of engineering to collect and distribute the water needed to "make the desert bloom."

During the first half of this century, great feats of engineering were the order of the day for the United States Bureau of Reclamation. By 1905, the Bureau was already involved in huge water projects across the West, and this was yet another opportunity for it to "improve" nature's work. ${ }^{13}$ Why, after all, had nature put the most powerful river in the world within spitting distance of these farmers, yet leave them in near-desert conditions? Boosters advocating an expansion of agriculture on the plateau saw the great potential of big dams along the Columbia and Snake Rivers for irrigation. But from 1905 until the mid-1930s, the Bureau of Reclamation took on 
the less ambitious but still impressive challenge of manipulating not the Columbia, but tributaries like the Yakima and the Umatilla. ${ }^{14}$

In 1905, the Bureau began several reclamation projects in the Umatilla River Basin. The Bureau constructed reservoirs at Cold Springs east of the town of Umatilla, and McKay (pronounced MUHKYE) south of Pendleton. ${ }^{15}$ The Bureau also built a series of diversion dams and irrigation ditches on the Umatilla's mainstem that snaked away from the river, traversing hillsides and winding away to farms outside the immediate river valley. As these projects began to water crops all over the basin, they began to have an impact on anadromous fish. The earthen dams created lakes that impounded important tributaries to the Umatilla, which reduced the instream flow and cut-off miles of stream habitat. The irrigation ditches had no screens to keep young fish from flowing into the fields with the water. The diversions diverted large quantities of water, impeded fish passage, and raised water temperatures to levels lethal to salmonids.

The river quickly began to dry up. More and more farmers acquired water rights from the state and more and more ditches slurped the precious fluid away from the river. By 1910, after most of the Bureau's projects had altered the river, boosters were calling for still more water. Sensing that the Umatilla's water would soon be spread too thin, the irrigators and promoters of economic development of the area called for a big dam on the Columbia at the Umatilla Rapids, where the pooled water could be spread over many more acres. Already irrigators could see that their 
expanding farming economy, putting more and more acres under cultivation, was in danger of over-appropriation. ${ }^{16}$

By the 1920s the Bureau of Reclamation and local irrigators put most of eastern Oregon's rivers to work. The Umatilla ceased to run year-round to the Columbia River. This suited irrigators, since the prevailing wisdom held that it was a waste for any unused water to escape to the Columbia. But this annual man-made drought coincided with the run of summer and fall chinook to the river. Migrating adults had to face what amounted to a seasonal annihilation of their habitat just at the time they needed it most. In July, August, and September, the lower Umatilla River became either a slow-moving mire of farm wastes, or totally nonexistent. ${ }^{17}$ The Umatilla winter steelhead were spared total destruction because their fortuitous migration brought them to the river in December, long after demand for irrigation water had subsided for the year, and after the winter rains allowed them the water they needed to make it to the headwaters where they spawn. By 1914, chinook and coho were virtually extinct from the Umatilla. ${ }^{18}$

The death of the Umatilla was not an isolated incident: the Umatilla was just one of many river basins in the Columbia Plateau and in the Blue and Wallowa Mountains, like the Walla Walla, the Grande Ronde, the Wallowa, and the Imnaha, that had its fish exterminated or severely stressed by irrigation. This local extinction of salmon was just a single instance of a larger environmental degradation. This was a sub-basin-by-sub-basin phenomena. 
After the First World War, the ambitions of boosters reached for more than the tributaries of the Columbia could provide, and the re-making of the waters of the Columbia Basin shifted from the tributaries to the mainstem of the Columbia and Snake. ${ }^{19}$ What had been local development, like the pursuit of irrigators on the Umatilla and Yakima rivers, or like the generation of hydroelectric power by private utilities on the Clackamas or Sandy rivers, was no longer enough. Men like Rufus Wood envisioned an "agricultural-industrial empire" based on irrigating the Columbia Plateau. ${ }^{20}$ This transformation of the focus of development from the local to the regional came about because of the economic imperative of Franklin Roosevelt's New Deal. Roosevelt employed economic initiatives that were national but applied according to the needs of each region. In the 1930s in the Pacific Northwest, New Deal recovery was based in part on the largest scale alteration the Columbia Basin had yet seen: the construction of the big dams.

\section{tex}

\section{The Northwest Power Act}

The impact of the mainstem dams is the other element crucial to understanding salmon restoration in the Umatilla Basin. The development of irrigation that dried the Umatilla and killed off salmon was a local effect. The federal development of the dams from 1938 to 1975 marked the change from local to regional effect on populations of anadromous fish. They created a series of blockages 
that hampered salmon and steelhead passing up and downstream. The dams acted as a sort of thrombus, clotting the artery of the river to the nutrients represented by salmon. They subjected each local salmon population east of the Cascades, no matter where it was ultimately bound, to pass through these clots that killed many fish. They regionalized salmon destruction.

The idea of developing the mainstem Columbia and Snake Rivers was originally a local proposition. "Boosters" from places like Wenachee, Washington or Umatilla, Oregon pushed the federal government hard for a dam on their reach of the river that would provide boom times for their local economies. Local needs in these communities differed from one another and required different projects. For example, in the 1920s people in Wenatchee wanted Grand Coulee Dam in order to create a huge irrigation project. Similarly, as early as 1918, farmers in Umatilla wanted access to more irrigation water too, but primarily wanted the Umatilla Rapids Dam (later called McNary) to help facilitate barge traffic by drowning several rapids on the Columbia and permitting crops to get to the markets in Portland and the rest of the world cheaply. ${ }^{21}$ To get this "open river," locals envisioned a series of dams and locks that would create the "Northwest Passage" of which entrepreneurs and explorers had always dreamed. ${ }^{22}$

With the entry of the federal government (the only entity in the 1930s with the capital to complete such massive projects), these projects spun out of local control. Despite their boosters' wishes, the dams would not be controlled locally, but were to become part of a regional system. The Army Corps of Engineers, which was 
initially against "multipurpose" dams, had surveyed the Columbia and Snake Rivers in 1927 for possible dam sites. The " 308 " reports projected an entire chain of dams strung like pearls on the mainstems of the Columbia and Snake. ${ }^{23}$ These would generate cheap hydroelectricity, provide flood control, produce more subsidized irrigation, and secure an open river. Beginning with the construction of Bonneville in 1938 and extending to Lower Granite in 1975, this string of dams made Lewiston, Idaho a seaport by transforming the Columbia and Snake from free-flowing rivers to a vast industrial machine. ${ }^{24}$

This machine also accelerated the decline of salmon in the mid- and upperColumbia Basin, a decline begun by irrigation and over-fishing. The first two federal dams, Bonneville and Grand Coulee (completed in 1938 and 1941, respectively), were watched carefully by fish biologists to ascertain their effects on the salmon. The construction of Grand Coulee was a disaster for salmon, although there was an abortive attempt to save upper-Columbia fish with a series of hatcheries. The dam annihilated the famed "June hogs" bound for spawning grounds in Canada. ${ }^{25}$ Biologists also watched Bonneville Dam anxiously, since this dam could potentially destroy all anadromous fish runs east of the Cascades. They breathed a sigh of relief when the fish began to use its huge ladders and passed upstream. But while Bonneville did cause fish some problems, this single dam in 1938 did not create an insuperable problem for salmon. It was the Corps' construction of an entire succession of dams over thirty years that was so devastating. 
This devastation is because the effects of the big dams have been cumulative. At each dam between $5 \%$ and $14 \%$ of salmon that attempt to pass are killed, both out-migrating to sea and in-migrating to spawn. While salmon bound for the Klickitat, Deschutes, or John Day rivers may suffer only moderate losses (with at most three dams to pass), it is easy to see the effects of this attrition on a Snake River population of sockeye, chinook, or coho, which must face as many as eight of these behemoths. These losses have crippled the ability of the upriver runs to sustain their numbers. ${ }^{26}$

The damage inflicted to salmon runs by dams is multifarious. It is perhaps worst for juvenile fish. The slow-moving slack waters behind the dams force smolts to run an already deadly gauntlet without the benefit of rushing water. Smolts face being shredded in dam turbines, cooked in too-warm water, eaten by predators who take advantage of slow moving smolts, and suffer lesions and exploding eyeballs from nitrogen supersaturation in a fall over the dam spillway.

Biologists recognized, at least superficially, the regional effects mainstem dams would have on salmon runs before Grand Coulee was completed. Congress attempted to legislate relief. The first major attempt was the Mitchell Act in 1938. The Mitchell Act established funds for a series of federal fish hatcheries that would offset, or "mitigate," the losses caused by the dams. ${ }^{27}$ But in the 1970 s, as salmon numbers continued to dwindle to precariously low numbers, and as more was understood about just how the dams were killing fish and how hatcheries contributed to the decline of native stocks, Congress again went to work. 
In 1980, Congress developed a mechanism to guide anadromous fish policy in the Columbia River Basin: the Pacific Northwest Electric Power Planning and Conservation Act. ${ }^{28}$ This Act established the Pacific Northwest Electric Power and Conservation Planning Council, a regional entity composed of two gubernatorial appointees from each of the major Columbia River Basin states: Oregon, Washington, Idaho, and Montana. ${ }^{29}$ The objective of the Northwest Power Planning Council is to reverse the decline of salmon populations and begin recovery by balancing the needs of the fish with the generation of hydroelectric power and other water uses. Part of the act's purpose is

to adequately protect, mitigate, and enhance fish and wildlife, including related spawning grounds and habitat, affected by such projects or facilities in a manner that provides equitable treatment for such fish and wildlife with the other purposes for which such system and facilities are managed and operated. ${ }^{30}$

This Council was charged by Congress to develop a comprehensive plan that would mitigate against and reverse the decline of salmon and steelhead runs in the Columbia River Basin east of the Cascades, the area effected by the big dams. With the words "equitable treatment," the Northwest Power Act did what no official policy had done before: it officially made salmon and hydroelectric power "co-equal."

This purpose makes the Northwest Power Act a groundbreaking piece of legislation. The language of the Act shows that the intent of Congress was for the agencies in charge of running the river-the Bonneville Power Administration, the U.S. Army Corps of Engineers, and the U.S. Bureau of Reclamation-to operate the 
river giving both anadromous fish and hydropower an even level of consideration. ${ }^{31}$ To coordinate the balance of salmon conservation and hydropower needs, Congress instructed the Council to use the best information gathered from the biologists who were the real experts in the field: those of the state fish and wildlife departments, federal agencies like the National Marine Fisheries Service, and the Columbia River Intertribal Fish Commission. The Act specifically forbade the Council to establish itself as a "super fish and wildlife agency." 32

As historian William L. Lang has pointed out, the forces that developed the river, BPA and the Army Corps of Engineers, sacrificed anadromous fish at every point as an acceptable cost to the perceived benefits of the dams, chiefly of cheap hydroelectricity. ${ }^{33}$ The Northwest Power Act promised to change that. No longer, according to the Act, could the needs of anadromous fish be ignored when operating the river; salmon must be given equal consideration. This equitable treatment, or "parity" as law professor Michael Blumm calls it, is crucial to interpreting the Northwest Power Act. ${ }^{34}$ To provide this parity, the Act lowered the "burden of proof" of scientific findings from absolute proof to "the best scientific knowledge available." By stating that biologists should proceed with "the best available scientific knowledge available," the Act made it clear that fisheries experts no longer needed absolute proof of how salmon might be helped or hindered by a given project. ${ }^{35}$ The intention of the Northwest Power Act was that harm or help to salmon and steelhead runs no longer had to be proved completely by biologists in order to carry administrative weight. Fish and wildlife experts were not required to study an 
issue to death in order to cancel a harmful project, alter a harmful operating procedure, or proceed with a restoration project.

Because Congress recognized specifically the dams' impact on the region's anadromous fish, the Act mandated that the agency in charge of marketing hydropower produced from those dams should pay for all salmon mitigation efforts endorsed by the Council. ${ }^{36}$ This meant an essential change in the way the Bonneville Power Administration operated. Since its creation BPA had been required to market the hydropower from the dams and pay back the federal treasury what the dams cost. The Northwest Power Act changed BPA's traditional mission from just marketing power to marketing power while paying for what has become the most expensive wildlife conservation plan in American history. ${ }^{37}$

\section{$x+x$}

\section{The Umatilla River and the Northwest Salmon Crisis}

In 1982 the Northwest Power Planning Council published the Columbia River Basin Fish and Wildlife Program. The program formulated a plan to revitalize salmon and steelhead runs that would comprise the entire Columbia River Basin east of the Cascades.

During in the late 1970s, the Confederated Tribes of the Umatilla Indian Reservation had developed a modest plan to boost the numbers of steelhead in the Umatilla River. After the passage of the Northwest Power Act, the Tribes approached the Council with a more ambitious plan to reintroduce chinook and coho 
salmon. The Council quickly recognized that the Umatilla had several inherent advantages for fish restoration. Because the Umatilla empties into the Columbia just downstream of McNary Dam, any Umatilla fish population need only pass three big mainstem dams: Bonneville, The Dalles, and John Day. The Council saw that a rehabilitated Umatilla Basin would be a large territory for producing fish, and contribute to its stated goal of doubling fish runs. ${ }^{38}$ It thereby included plans for the Umatilla in the 1982 Columbia River Basin Fish and Wildlife Program.

In 1984, the Council backed-off stating actual goals for anadromous fish recovery. The Tribes and the fish and wildlife agencies wanted fish numbers up to their pre-McNary Dam levels. ${ }^{39}$ The Pacific Northwest Utilities Conference Committee (PNUCC), an umbrella organization that represented the Direct Service Industries (which included aluminum manufacturers), consumer-owned utilities, and investor-owned utilities that were dependent on wholesale rates from BPA, objected, claiming that the pre-McNary numbers of fish were too high. ${ }^{40}$ The Council steered a middle course, and decided to postpone articulating any goals until after a study by BPA that would evaluate "past, present and potential production." ${ }^{41}$ The Council's reaction to PNUCC, a consortium tied fundamentally to the river's hydropower, setting aside the recommendations of biologists, show that politics and not biology were already influencing decision-making. But irrespective of the Council's ambivalence toward specific goals, it supported two specific ideas for rebuilding salmon runs in the Yakima and Umatilla basins. 
The NPPC was not mandated by Congress to deal specifically with Indian fishing rights, although it was required to consult the Tribes. Nevertheless, the Council understood that meeting the Umatilla Tribes' goals would help meet its own. The Fish and Wildlife Program was "designed throughout to restore fish runs by improving fishery habitat so that Indian tribes will be able to realize the rights secured by their treaties." ${ }^{, 22}$ The goal of doubling the number of salmon in the Columbia River Basin, honoring treaty obligations, combined with geography to make the Umatilla one of the Council's highest priority fish restoration projects.

The act charged the Council to produce a program that would reverse the damage to salmon runs by the dams.

The Council shall promptly develop and adopt.... program to protect, mitigate, and enhance fish and wildlife, including related spawning grounds and habitat, on the Columbia River and its tributaries. Because of the unique history, problems, and opportunities presented by the development and operation of hydroelectric facilities on the Columbia River and its tributaries, the program, to the greatest extent possible, shall be designed to deal with that river and its tributaries as a system. ${ }^{43}$

To deal with the Columbia as a system would require the Council to take a broader approach than past mitigation efforts had undertaken. The charge to approach the tributaries as a part of the Columbia opened the door for the Umatilla program. Previously, projects that had been designed to mitigate the effects of dams were located physically near the dams. For example, many Mitchell Act hatcheries were placed right along the river or on tributaries very close to Bonneville Dam, such as Carson Hatchery or the Wind River Hatchery. Others, like John Day Dam, had dual Oregon-side/Washington-side hatcheries as part of their original design. It was a 
simple zero-sum game: as a dam destroyed salmon, its neighbor hatchery would replace those salmon. Thus there was a direct spatial relationship of dam to hatchery, between damage and mitigation.

However, the Council saw beyond this cause and effect relationship of damage-to-mitigation. To truly double the numbers of returning salmon the Council redefined the idea of mitigation in more ambitious terms. It did so by expanding the space where mitigation projects could be implemented. In an effort to decentralize hatchery production, which biologists understood was in itself unhealthy to wild fish stocks, and which the Tribes recognized as crucial to getting salmon back into tributaries, the Council decided that mitigation projects should take place in the subbasins where historically strong populations of salmon once spawned. In effect, the Council said that injury to anadromous fish by the dams could be mitigated by projects "off-site." The Council radically altered the definition of mitigation by including such projects that were far from the source of the damage. ${ }^{44}$

The Council's new interpretation of mitigation created a relationship that had not previously existed between the big mainstem dams and the Umatilla Basin. The big dams had nothing to do with the demise of Umatilla salmon: Umatilla salmon were extinct at least ten years before the first dams came on-line. Even though the damage to the Umatilla salmon populations was not hydropower related, the NPPC saw restoration of Umatilla salmon as exactly the new kind of mitigation it was proposing. Also, by adopting the Tribes' proposed program in the Umatilla Basin, it would be furthering its own goals while conforming to its mandate of remaining 
sensitive to the tribal perspective. This interpretation would arise later as a legal issue as opponents to BPA expenditures began to line up against the program. Nonetheless, the NPPC saw the Umatilla Basin as an ideal place for a mitigation project, a unique opportunity.

Because the Council decided to use the Umatilla Basin as a mitigation project, the Confederated Tribes of the Umatilla Indian Reservation suddenly gained financial support of the Bonneville Power Administration for its restoration program. With this new source of funding, the Umatilla, Walla Walla, and Cayuse Tribes, with the help of the Oregon Department of Fish and Wildlife, revised a steelhead hatchery plan that the two had drafted in the late 1970s. This new plan was exponentially more ambitious: it called for a system of hatcheries that would reintroduce naturally spawning chinook to the Umatilla Basin. This idea itself was a radical departure from the traditional concept of hatcheries, which were little more than fish factories producing meat for "harvest." The Council saw the Umatilla Basin as a functional nursery for the production of thousands of salmon. The Tribes envisioned a Umatilla River resurrected from seventy years of spiritual death.

\section{$m m m$}

THE DEMISE OF THE GREAT SALMON RUNS has created a profound sense of distress among Pacific Northwesterners. The perception is that an animal that has become an indispensable icon of the region is disappearing. ${ }^{45}$ This sense of "crisis," dubbed the Northwest salmon crisis, is an issue far too vast to tackle in this, or any 
single, essay. ${ }^{46}$ But by looking at the recovery of a medium-sized river in the heart of the Columbia Basin we can glimpse what it might take to revive the numbers of anadromous fish in the rest of the Basin, and the extraordinary problems such revival will face.

During the 1990s, the Northwest salmon crisis became the most complex natural resource issue in the nation. The range of Columbia River salmon is immense, with many stocks of salmon and steelhead listed under the Endangered Species Act as either threatened or endangered. These listings, coupled with the treaty rights of the Columbia River Indians and the statutory authority of the Northwest Power Act, means that there are complex legal issues at play.

Scientists know far less about anadromous fish than they would like. If they do not fully understand the salmon's life in fresh water, they know next to nothing about its pelagic life. The combination of genetics, run timing, and homing instinct, among others, renders much biology as best guesses.

The fact is that almost anything that humans do to the land hurts anadromous fish. Farmers with uncovered heaps of manure in the Willamette valley; residents washing their cars in their driveways in Portland; ranchers with cattle wading in streams on their property on the John Day River; farmers opening valves on irrigation ditches near Echo on the Umatilla River; loggers clear-cutting a section of forest in the headwaters of the Clackamas River; the longshoreman at the grain elevator in Arlington on the Columbia; the excavation of a foundation for a hillside home on the White Salmon River; the writer sitting at his desk turning on the electric 
lights of his home on Mt. Hood; all these things hurt salmon. And all these things are tied to the way Northwesterners make a living. These people are political constituencies with congressmen who have similar sensibilities.

Cultural values of both Indian and non-Indian passionately cry out for recognition. Environmentalists have raised the awareness of other Euro-Americans in the region, and helped all to see salmon as part of our "natural heritage" instead of merely a commodity. Native peoples have a much older and sophisticated relationship of sustenance, prosperity, and spirituality with Columbia River salmon than non-Indians. Because of the Treaties of 1855, Indians possess the legal right have salmon in the rivers. It is a bewildering combination of legal, cultural, economic, political, and biological considerations that make a student of the salmon crisis throw up his hands in the face of these seemingly intractable conflicts.

But are they intractable? Here we shall examine a success story. The historical importance of the Umatilla River as an expression of the Northwest salmon crisis is three-fold. First, it represents the way river systems in eastern Oregon had their salmon and steelhead decimated, if not totally wiped out. The Umatilla River Basin exemplifies the kind of habitat loss typical of the Plateau. Second, the Umatilla experience exposes how bureaucracies can resist making the necessary changes for the sake of salmon restoration. Third, and perhaps most important, the Umatilla story demonstrates the importance and determination of tribal people to be a vital force in salmon recovery. 
At the core of this story is a river that lay dead for decades. The Native Americans who relied on that river wished to change that, to resurrect the river. The Tribes, using complex legal and financial mechanisms, coupled with increased political strength, began to execute an involved plan to revive the river. But the mechanism for funding the plan threatened to break down; the politics of Columbia River system management was far too entrenched in the old way of running the river to allow the plan to proceed unimpeded. The Umatilla River Fisheries Restoration Program was stalled for five years because of institutional inertia and stubborn, intractable personalities.

This first chapter has laid out the major background issues: the death of the Umatilla, the legislative framework of recovery, and the place of the Umatilla in a greater atmosphere of crisis. Chapter II further contextualizes the Umatilla program by exploring the foundations of the relationships between Indians, salmon, and hatcheries to give meaning to how powerful is the idea of restoring the Umatilla. Chapter III examines what this program is, how it came to be, and what it meant to certain bureaucrats at the Bonneville Power Administration who could not successfully adjust to a world where biology was equal to engineering. Chapter IV looks at the key to remaking the Umatilla: large amounts of water and how it was to be delivered. And the Conclusion summarizes the place of this program in the larger context of natural resource allocation in the Columbia River Basin.

By examining this success story, we can better understand some of the relationships and struggles that keep salmon the top natural resource concern in the 
Pacific Northwest. The Umatilla River is again a salmon stream. ${ }^{47}$ Threats to its regained status persist, but for now the Umatilla Indians have fulfilled a dream of generations. It was salmon that enabled Plateau Indians like the Cayuse, Walla Walla, and Umatilla to make the Columbia region home in the first place. The Indians were there because of the salmon. ${ }^{48}$ Now, the salmon are in the Umatilla River because of the Indians. 


\section{CHAPTER II-INDIANS, SALMON, AND HATCHERIES}

The last Salmon is divided, only a segment of understanding that is accepted with the River. Placing the Salmon head facing upriver will demonstrate we have not absolutely conformed. Only two hundred years from the discovery, dear Chewana the unfolding of unwritten prophecy, a Great River is fragmentary holiness.

-Elizabeth Woody ${ }^{1}$

\section{$m m m$}

THE RESTORATION OF SALMON TO THE UMATILLA RIVER by the Confederated Tribes is a very specific, local story. Understanding why this is important on a larger scale, to Indians and salmon, means understanding the nature of relationships between Columbia River Indians, Pacific salmon, and the artificial propagation of anadromous fish. Each is complicated enough to justify a full-scale examination. This study will confine itself to a cursory look at the three, but their interaction is crucial to comprehending projects like the Umatilla Fisheries Restoration Program.

If ever the phrase "destinies intertwined" was appropriate or meaningful, it is in the instance of Indians and salmon. It is impossible to understand salmon in the Columbia River Basin (and probably the entire Pacific Northwest) without understanding their relationship with the native peoples. The two are inseparable. Historically, mid-Columbia River Indians defined a great part of who they were- 
their material and spiritual culture-by the salmon they caught in the Columbia and in its tributaries. Salmon sustained body and spirit. And there is evidence that this relationship was reciprocal; some biologists and scholars believe that Native American salmon management actually enhanced the runs of anadromous fish. ${ }^{2}$

It is an ancient relationship. The Plateau peoples have depended upon the salmon runs for thousands of years. It is not a static relationship, but one that has changed in marked ways over the last hundred years. At its root is, again, reciprocation. In one of the most poignant legends on the Plateau, the Creator asks the animal people which of them will be willing to sacrifice their bodies for the good of the new-come human beings. The salmon people tell the Creator that they will agree to give up their bodies, but under one condition. They will also relinquish their voices to the Plateau people, and it will be the responsibility of human beings to be the voice of the salmon. In other words, it is up to tribal people to speak for salmon, since salmon have no voice of their own. So their Creator charged the people of the Plateau with this solemn duty.

The relationship of non-Indian managers to salmon is based on manipulation. For a hundred years, fish managers tried to engineer salmon stocks to fit the society's expectations of salmon rather than the needs of salmon. Looking back, their techniques seem primitive, inept and ignorant. The impact of these primitive hatchery practices on salmon stocks has been immense. Biologists estimate that up to $90 \%$ of all salmon in the Columbia Basin today are descended from hatchery stock. ${ }^{3}$ The operation and reliance on hatcheries has also affected the view of fish managers. 
Besides relying on this technological management tool for "improving" the survival of fish, state fish and wildlife agencies also became addicted to the federal funds that pay for hatchery operations.

State and federal control over fish hatcheries, along with the traditional distrust between the states and the Tribes, has also retarded meaningful progress toward coherent policies that will restore salmon. More money for tribal hatcheries means less money for some other agency. Also, clashes between agency and tribal scientists over genetically "safe" hatchery practices hamper the development of cohesive strategies, because in the 1990s the federal government backed away from hatcheries at the same time that the Tribes turned to hatcheries as a method of resurrecting dead or dying rivers.

Native people are entitled to a place in the salmon discussion. Northwest Indians earned their seat at the table in the struggle to make the Treaties of 1855 respected in the 1960s and 1970s, culminating in U.S. vs. Washington. ${ }^{4}$ This chapter looks at this triangle of relationships-salmon to Indians, salmon to hatcheries, and Indians to hatcheries-which is one of the central elements in the story of salmon restoration in the Umatilla River Basin, and in the Columbia Basin as a whole.

The complexity of the salmon crisis is compounded by the complex life cycles of Pacific salmon. The Columbia River Basin has five species of salmon and two of anadromous trout. These seven make up the genus oncorhynchus, or "hook nose." They are the chum, pink, coho, sockeye, and chinook, and the sea-run trout are the cutthroat and steelhead. ${ }^{5}$ Pink and chum salmon and cutthroat trout rarely if 
ever come upstream as far as Bonneville Dam. Coho (or silver salmon, O. kisutch), sockeye (or blueback, O. nerka), and chinook (called king salmon outside of Oregon and Washington, O. tswawycha) migrated into the interior of the Columbia Plateau in vast numbers. These three salmon, along with the steelhead (the sea-run version of rainbow trout, $O$. mykiss), were heavily relied on by the mid-Columbia River Indians.

Chinook and to a lesser degree steelhead have evolved into regional and temporal subspecies. There are winter and summer steelhead (with summer steelhead having an additional so-called " $\mathrm{A}$ " run that migrate slightly earlier than the " $\mathrm{B}$ " run). Chinook have adapted into spring, summer, and fall runs. Fall chinook are further divided into "bright" and "tule" runs, descriptions based on fish coloration and behavior; "upriver brights" enter the Columbia early and tend to migrate farther upstream. Their flesh is much firmer and brings a better price to commercial fishers than the tules, which are darker fish that enter the Columbia late, already losing much of their body fat, the fat that makes salmon such a delicacy.

The Umatilla River historically had runs of summer steelhead, coho (a fall migrator), and spring and fall chinook. For the purposes of this narrative, we will discuss only these three, since it is these that the Tribes attempted (and continue to attempt) to restore. ${ }^{6}$ 


$$
\text { H }
$$

\section{Indians and Salmon}

The relationship between Pacific salmon and Columbia River Indians is a relationship that has evolved over perhaps 10,000 years. Tribal relationships to salmon are best understood on their own terms rather than through traditional scholarly techniques that tend to classify, to categorize, for example, in terms of instrumentalist, utilitarian, or functionalist. As the scholar Vine Deloria, Jr. has written, Indian metaphysics are based on individual relationships, rather than categorized frameworks. "The key to understanding Indian knowledge of the world is to remember that the emphasis was on the particular, not on general laws and explanations of how things worked."7

[In the Indian worldview] power and place are dominant concepts-power being the living energy that inhabits and/or composes the universe, and place being the relationship of things to each other. It is much easier, in discussing these Indian principles, to put these basic ideas into a simple equation: Power and place produce personality. This equation simply means that the universe is alive, but it also contains within it the very important suggestion that the universe is personal and, therefore, must be approached in a personal manner. And this insight holds true because Indians are interested in the particular, which of necessity must be personal and incapable of expansion and projection to hold true universally. ${ }^{8}$

Each relationship requires a measure of respect and reciprocation. Each is personal, and therefore contains a measure of the sacred. Columbia River Indians recognized their reliance on this great fish, and reciprocated with ceremonies and management techniques that aimed at insuring a continued relationship. While it is 
seductive to the scholar to attempt to break down this relationship into three more or less distinct categories (material, spiritual, and legal), it is reductionist to do so. Native Americans did not then and most still do not separate the world so neatly. The dualist worldview of Euro-Americans allows them to easily divide the sacred from the profane, allowing a clear distinction between Holy Communion and commodity. Traditionally, Columbia River Indians had no such dual nature, did not divide the world up into categories, and did not understand this viewpoint. They did not behave in a secular way during the week, and then a sacred way on Sunday. For them, their relationship with salmon, elk and deer, and the roots and berries gave sustenance, and that was to be respected as a sacred relationship. To separate this relationship into what appear to be the constituent elements of material reliance, spiritual sustenance, and legal interdependence is somewhat arbitrary, yet however clumsy these terms are, they are the only tools we have for understanding this complex weave of relationships.

The first and most obvious element is that of sustenance. People have to eat, and in the dry Columbia Plateau the most abundant and reliable source of protein was salmon. Columbia River Indians devised many ways to catch and preserve these fish for the long winter months when there would be little fresh meat and almost no other source of protein.

Before non-Indians came to the Pacific Northwest, between 16 and 11 million salmon a year entered the Columbia, finding their way up its tributaries to their natal streams. Native Americans all over the Pacific Northwest caught them in 
great numbers, especially the Indians of the Columbia Plateau. Some scholars estimate that the Columbia River Indians took around 39\% of the fish in the river in a good salmon year with strong runs of returning fish. In a bad salmon year, Indians took as much as $67 \%$ of the salmon struggling upstream. ${ }^{9}$

Some scholars go so far as to suggest the possibility that native fishers helped thin the fish so that spawning grounds did not become over-crowded with competing fish, which helped a higher percentage of redds (nests) to survive and not be destroyed by other fish trying to establishing their territory. This idea, then, suggests that salmon and Indians had a kind of interdependent, symbiotic relationship from the very beginning. ${ }^{10}$

Columbia River Indians' material and social culture became grounded firmly in the great abundance and desirability of salmon. It took many pounds of dried salmon to keep a family alive over the long winter months on the frigid plateau. What people did not need they traded. This trade brought thousands of Indians to Celilo Falls during the fishing season to exchange dried salmon for buffalo hides from Plains Indians to the east, obsidian from the Modoc and Klamath to the south, and dentalium shells from Chinookan peoples from the coast and lower-Columbia. These were great social gatherings where

wealth was exchanged and alliances formed. Marriages were arranged, betrothal ceremonies performed, horses traded and raced, gambling - such as stick games - was enjoyed, and families were reunited. ${ }^{11}$ 
Salmon brought great material and social prosperity to the people of the Columbia Plateau.

Despite the incredible amount of fish caught, the salmon always came back; native fishers did not destroy the runs—quite the opposite. Plateau Indians had a number of management techniques, many not obviously directed at the fish, but rather the safety and spiritual health of the clan or tribe. Some restrictions were based on ceremonies. For example, certain marriages and ceremonies required the fishing master, or "salmon chief," to declare a day (or week) of no fishing to properly honor the two families newly joined. If a fisherman fell into the rapids at Celilo and drowned, the salmon chief would call a halt to the fishing that particular hole for a period of time to allow that man's spirit to get out of the river. This allowed the people to avoid the spirit haunting them. ${ }^{12}$

Another "technique" depended on a combination of usufructory fishing rights and a dispersed fishery. Only certain families had rights to fish at certain places on the river, hereditary rights that were passed down patrilinearly. A man could give permission to another man to fish from his spot, but it was not given lightly. These were not rights to own a particular fishing spot, but rights to fish from that spot - they were usufruct rights. This system effectively regulated fishing at a place like Celilo Falls since it limited who could fish there. It pushed other fishers onto other places on the Big River and many others into the tributaries, where Indians fished effectively with different techniques; the dipnet gave way to the gaff hook. 
This dispersed fishing throughout the plateau so that no one area was too intensively fished. $^{13}$

These techniques resulted in giving salmon a period of respite from capture, what modern salmon managers refer to as "escapement." Those fish were allowed to travel upstream, to be captured by other hunters — bear, eagle, otter, other people—or to spawn. Other observances had the same effect: ceremonies that required the cessation of fishing at that particular hole, and thus provided escapement of more fish. $^{14}$

Traditionally mid-Columbia River Indians believe that the Creator sent the salmon people upstream to sustain humans. Salmon fed the soul as well as the body. Warm Springs/Wasco poet Elizabeth Woody puts it succinctly: "Salmon was a key element in the spiritual framework of [native] -people: purity of foods, purity of thought, purity of body." 15 The most obvious demonstration of this is the "first salmon ceremony," which is a common ritual with other Tribes throughout the Northwest: a celebration and reverence of the first foods. Indians all along the Columbia, whether lower, middle or upper, celebrated the return of the salmon with a corresponding rigor, depending on how reliant they were on salmon. With local variations based on the importance of salmon to the tribe, the first salmon was caught, with great ceremony prepared, and a mouthful was given to all in the tribe. ${ }^{16}$ The skin, bones, and viscera were reassembled and put back into the river to swim back to the sea, to tell the salmon people that they were being respected, that it was all right to come upstream. 
We should not confuse this concern with the health of the salmon runs with modern environmentalism. Too often the romantic notion of the Native American as the "first environmentalists" has clouded a more accurate picture of their interaction with the land. This interaction is based first and foremost on individual relationships. Since each relationship, whether with a person, an animal, or the land, is a unique, particular relationship, each relationship must be taken at face value. Indian management styles functioned upon an ethic that recognized respect and reciprocation. It resembled the Euro-American idea of stewardship. Unlike EuroAmericans, however, their creator required them to show due respect to the other "peoples" with whom they shared the land. Above all, Native Americans were pragmatic: respecting the "salmon people" meant maintaining the spiritual health of the tribe, a kind of enlightened self-interest. ${ }^{17}$

Current legal, biological, and economic arguments about salmon restoration, coupled with much recent scholarship, have downplayed the importance of the Indians' spiritual relationship with salmon. Anthropologist Eugene Hunn, an ethnobotanist, has de-emphasized the role of salmon in the spiritual lives of Columbia River Indians in order to emphasize the undervalued role of women in the gathering and preparing the many plant resources needed by plateau peoples-a laudable goal, but one gained at the expense of salmon. Historian Joseph Taylor has effectively argued that Native Americans could and did catch as many salmon as they wanted without harming the runs. But his emphasis on economic relationships as determining factors in understanding Indians' contemporary relationship to 
salmon discounts the Indians' spiritual relationship in order to portray Indians as river user group —a political constituency - that have an interest in salmon. This casts Indians in a very different light, implying that Columbia River Indians are merely another faction of river users with an agenda for the river, hiding behind the screen of their religious beliefs to justify their position. ${ }^{18}$ It is a rather cynical position that simplifies a factual, historical relationship, one that continues to motivate the Tribes and is a force in their salmon restoration policies. Indians themselves use the spiritual aspect of salmon as the basis of their argument less and less in the current, highly charged political landscape. ${ }^{19}$ The fact is, in their own terms, the respect an Indian pays the animal that keeps him or her alive is a spiritual relationship. The regard a person has for their own traditions taught by their elders, the stories and myths that one relies on for guidance, and the ceremonies that one performs for kith and kin and clan--inasmuch as these are spiritual relationships, then the relationship of Columbia River Indians to salmon is undeniably spiritual.

While still vital to the culture of plateau people, this relationship has changed. It has changed because they cannot find sustenance in salmon alone: there simply are not enough fish to sustain any population of people. Indians still catch fish on the Columbia, but they sell most of the fish rather than dry it for their own use. During the fishing season, whites gather at parking lots near boat ramps, to buy fish from Indian youths who haul great salmon and steelhead out of plastic coolers. There is also much greater competition for salmon: Indians have had to share this resource with Euro-American fishers. It is out of this struggle, this competition for a 
scarce resource, that the most modern relationship of Indians to salmon has emerged, the legal relationship.

Salmon were so integral to the lives of Northwest Indians that they made fishing a major issue in treaty negotiations with Washington Territorial Governor Isaac Stevens and Oregon Territory Indian Superintendent Joel Palmer. In 1854 the United States Government sent Isaac Stevens to facilitate the movement of Indians off the land so that white settlement could proceed unabated. With great alacrity, Stevens convinced the Indians west of the Cascades to sign treaties, and then proceeded to the dry interior to deal with the east-side tribes, including the Sahaptinspeaking people of the Columbia Plateau.

Like the west-side Puget Sound Indians, the Plateau People were extremely unhappy to be asked to give up their lands, more than $12,000,000$ acres in Oregon alone. ${ }^{20}$ But they remained adamant on their unimpeded right to fish. Stevens obliged on the issue of fishing rights, and included language that Native Americans retained their fishing sites at the "usual and accustomed stations" to fish "in common" with whites. ${ }^{21}$ The tribes on both the Puget Sound and the Columbia River were thus guaranteed their traditional fishing grounds. These were not privileges given to the Indians by a conqueror, but were rights reserved by an agreement between sovereigns. These treaties, therefore, should be seen as exchanges, where the Indians conceded their historic range and in return had their fishing rights recognized by the United States. ${ }^{22}$ "This guarantees your fish." With these words, Stevens insured 
Indians all over the Pacific Northwest a place at the salmon management table over one hundred years later. ${ }^{23}$

At the time of the negotiations, expediency dictated that Stevens not haggle overmuch, and he met this condition with few qualms. Both Stevens and Palmer could see that in their plan of temporary solutions to acculturate the Indians the Indians would need sustenance. ${ }^{24}$ Stevens' thoughts that Indians would never compete with whites were based on two assumptions about fishing that turned out to be wrong. The first was that Indian fishing techniques were inefficient. We now know that a population of fishers capable of taking as much as two-thirds of the catch could not have been inefficient; Indians were capable of catching as many fish as they wanted. ${ }^{25}$ The second assumption was that the value of salmon to whites was negligible since there was no large-scale market for it. Local markets for salmon were small and necessarily confined to areas where salted or jerked salmon could be shipped without spoiling. The famed international market for canned Columbia River salmon was still a few years away. Therefore, fishing offered Euro-American settlers few economic opportunities. In retrospect, it was easy for Governor Stevens to agree to the Native American position maintaining their unfettered ability to take salmon. Stevens' assumptions were wrong. The introduction of canning to the Pacific Northwest in the 1860s created the conditions where white fishers did come into aggressive competition with Indians. Canning created a method of processing and transporting salmon thousands of miles without fear of spoilage. ${ }^{26}$ When this technology reached the Pacific Northwest it caused the economic value of salmon to 
skyrocket: The rights only just reserved by Native Americans ten years earlier came into serious contention with whites as a result of competition with white fishers and the Tribes' insistence on using their traditional fishing places, some of which were now private property.

This friction between Indian fishers and non-Indian fishers and landowners led to major disputes. The general theme in these conflicts is that the state or territory would rule in favor of non-Indians against the Indians, and then the United States Supreme Court would overrule the state court in favor of the Indians. The first case to match this pattern and to reach the Supreme Court was United States v. Winans in 1905. The issue arose over the property right of the Winans brothers to build a fishwheel on a traditional Yakama fishing spot on the Columbia, a "usual and accustomed" place. The Winans' argued that their property right was assured by the statehood of Washington. They maintained that statehood negated Article III of the treaty, which promised Indians the rights to fish at all the usual and accustomed places, since the land now came under the sovereignty of the State of Washington, not the United States of America. ${ }^{27}$ The state court of Washington agreed. But the U.S. Supreme Court overruled the Washington court in favor of Native Americans, saying that they could not be kept from their usual and accustomed places by private property, since their fishing rights was a kind of property right. With inspired prose, Justice McKenna wrote that salmon "were not much less necessary to the existence of the Indians than the atmosphere they breathed. ${ }^{28}$ Three years later, the same Court ruled that Indian tribes had implied reserved rights to more than just fish. In 
Winters $v$. United States, the Court ruled that water rights were also held by the tribes as reserved rights. ${ }^{29}$ While this has little to do with fishing, per se, this case has stunning implications.

The Winans decision made the Treaties of 1855 the law of the land. It laid the foundation necessary for the Tribes to assert their rights and challenge the increasingly restrictive fish and game laws of the states. It is unnecessary to recount here the entire judicial history of Columbia River Indians' fishing rights. But briefly, four more cases in the late 1960s and 1970s set the stage for the Indians modern role in the salmon crisis.

The first decision was Sohappy v. Smith in 1969. Based on his interpretation of the 1855 Treaties and Winans, Federal District Court Judge Robert Belloni ruled that Indians were entitled to "a fair share" of the salmon in the fishery. In 1974, Judge George Boldt went one great step further. In United States v. Washington, a complicated ruling over one hundred pages long, Judge Boldt interpreted Judge Belloni's "fair share" to mean "equal." He continued by defining equal to be $50 \%$ of the catch. To implement what became Phase I of his decision, Judge Boldt in effect made himself the fish-master for the Columbia River and Puget Sound. The Boldt decision granted well-organized tribes like the Yakama the right to self-regulate their own fishery, and it officially made the Indians full partners in the already complex world of salmon management. While non-Indian commercial fishers off shore and in the Puget Sound howled in protest, burning Judge Boldt in effigy, United States v. Washington became a landmark of law for both salmon and Northwest Indians. ${ }^{30}$ 
The Supreme Court upheld the Boldt decision in 1979. In Washington $v$. Passenger Fishing Vessel Association, Justice Stevens wrote for the majority: "a treaty, including one between the United States and an Indian tribe, is essentially a contract between two sovereign nations." ${ }^{31}$ The Court also interpreted the treaties to mean more than merely guaranteeing access to fishing places. The treaties intended the Tribes to "a share of each run" of fish and the share had to be equal. ${ }^{32}$ The Court had put to rest the issue of whether or not the Tribes had a right to the fish.

In 1980 Judge William Orrick handed down his ruling on Phase II of United States v. Washington. This Phase dealt with two issues that Judge Boldt had set aside in 1974: the inclusion of hatchery fish to the fishery, and the effect of habitat on salmon populations. The State of Washington, which only reluctantly implemented Phase I, had been excluding hatchery fish from state hatcheries from the Indians share of the $50 \% .{ }^{33}$ Judge Orrick wrote that without hatchery fish (which account for as much as $90 \%$ of the fishery), the treaties would be made meaningless. ${ }^{34} \mathrm{He}$ specifically stated that the Indians' $50 \%$ included hatchery fish. In regard to habitat, Judge Orrick also ruled that Washington was to "refrain from degrading the fish habitat," since that had a desultory effect on overall fish numbers. While the Ninth Circuit vacated Judge Orrick's ruling on habitat, stating that it was too sweeping a regulation, it upheld his decision that hatchery fish were part of the equation. ${ }^{35}$

The judicial history of Indian fishing cases combine with the 1907 Supreme Court decision Winters $v$. United States to recognize and confirm the legal standing of Columbia River Indians in salmon management. The Boldt decision is 
fundamental to the mechanics of salmon recovery efforts, because it grants the Tribes autonomy in managing their own fishery and requires other river users and managers in the region to sit at the table with treaty Indians. ${ }^{36}$ Winters $v$. United States further enhances the tribal position by recognizing tribal rights to other resources on ceded lands. The Winters decision will be discussed in detail in Chapter IV. Briefly, the Winters Court ruled that Indian tribes reserved water rights on their ceded lands. Because Winters ruled that Columbia River Indians gave up only their title to the land, retaining rights to water and other resources, Indians have legal standing in natural resource policy making in the Columbia River Basin. Between the Boldt decision and the Winters Doctrine, tribes like the Umatilla have the right to administer fish restoration policies on reservations like the Umatilla, and off the reservations on the so-called ceded lands, like on the Walla Walla River and the Grande Ronde River. ${ }^{37}$

These rulings enhanced the legal standing of the Tribes within the framework of fish and rivers management, and from them Indians take the legal strength they need to advance their ideas on salmon restoration. But the promise of the Treaties and the law were not enough to keep the Tribes in fish. At the same time that the courts and the federal government supported the Indians' right to fish, EuroAmericans continued to alter the environment and so threatened to make many of those promises irrelevant. Irrigation, as in the Umatilla Basin, destroyed habitat and eliminated many runs. Logging did the same. Dams not only killed fish as they passed, but obliterated traditional fishing places and significantly altered the riverine 
environment. In particular, Native Americans saw the drowning of Celilo Falls as a catastrophe. ${ }^{38}$ Only in the past twenty years, with the passage of the Northwest Power Act, have the Tribes been able to promote their own restoration strategy.

Between their determination to keep their traditions alive and favorable rulings by the courts, the Tribes have forced the machinery of salmon management in the Pacific Northwest to swing around, away from the ocean fishery that concerned past hatchery practices. Federal and state fishery managers and politicians must now address upstream issues that before the Northwest Power Act were only given cursory inspection. Native peoples capitalized on this new law by pushing for restoration projects on their reservations and their ceded land.

$$
\text { HE }
$$

\section{Salmon and Hatcheries}

Hatcheries have operated in the Northwest since the 1870s. They were the cornerstone of fish management in the early and middle part of the century, considered indispensable to maintaining a strong commercial catch. As Historian Joseph E. Taylor has put it, the state of Oregon assumed it could avoid regulating overfishing and upstream activity suspected of harming salmon runs by simply "making salmon." By removing salmon propagation from uncertain nature to a scientifically controlled environment, officials did not have to face the consequences of rampant environmental degradation. ${ }^{39}$ The construction and operation of 
hatcheries was far from consistent or credible until the era of the big dams. In the 1940s the federal government became involved in mitigating fish losses inflicted by mainstem dams. Hatcheries became institutionalized, and were operated in a rationalized way rather than the haphazard fashion of the nineteenth century. Still, they proved no more effective in building-up salmon runs.

By the late 1880s, it was clear that the numbers of big chinook were in decline. Fishers who had never taken anything but chinook now began to pursue coho and sockeye. ${ }^{40}$ In the 1890 s, the dip in the catch was profound, with numbers plummeting from over 40 million pounds to 25 million pounds. The catch would continue to peak and valley radically until the $1930 \mathrm{~s}^{41}$ Sometimes violent struggles (called "fish wars") broke out on the lower Columbia, as commercial fishers blamed rival types of gear for being particularly rapacious. Northwest residents blamed all commercial fishers for the decline of salmon, with Oregon voters passing several ballot measures aimed at curbing what they saw as the inevitable extinction of chinook. $^{42}$

But scientists were beginning to understand that more was going on than just over-fishing. From the 1870 s to the 1920 s, spawning and rearing habitat were being destroyed or degraded as the interior of the Northwest was developed. Large-scale mining operations devastated streambeds. Logging the forests diminished shade of rivers and increased water volume and sediment loads, burying spawning beds. Extensive cattle ranches disturbed fragile riparian zones. And more farms on the semi-arid plateau demanded more irrigation water, sucking rivers dry. It was not any 
one of these practices that depressed the upstream runs, but, as historian William Robbins has stressed, "it was the combined farm, range, mining, and forest activities that proved so disruptive to stream and riverine ecology in the region." ${ }^{.43}$

As salmon numbers continued to decline in the 1920s and 1930s, the states of Washington and Oregon tried to regulate fishing. But the inability to enforce new regulations hampered the state's efforts. The fish wars heated up as each group of fishers tried by ballot measure to exclude rival types of gear. Horse seines, fishwheels, gillnets, and others all came under fire as various groups, including sports fishers, convinced the public that excessive commercial fishing was annihilating the Northwest's salmon. ${ }^{44}$

In order to compensate for both the elimination of freshwater habitat and overfishing, fish and game managers began to rely on artificial propagation as the chief tool to insure the continued abundance of salmon. Commercial salmon interests, sports fishing interests, and fish managers saw hatcheries as the saving grace. In addition, hatchery production of salmon meant that Northwesterners could continue their various ways of making a living exactly as they were. Loggers in the Coast Range and Cascades, farmers, ranchers and miners in the semi-arid interior could all continue unimpeded by regulation since any harm to the salmon could be rectified by making more. No regulation of the fishery, nor restrictions on logging practices, nor new farming techniques were necessary, because fish managers could produce more salmon by far than were taken. ${ }^{45}$ 
Fish managers in the nineteenth-century pursued artificial propagation at a time when sound, scientific knowledge of salmonid biology and behavior was thin at best. Experts on salmon, such as Robert Hume and Livingston Stone, were few and their knowledge dubious. Hume, an acknowledged contemporary expert who grew rich canning Rogue River salmon, maintained up to his death his conviction that Pacific salmon did not necessarily die after spawning. ${ }^{46}$ Stone was the assistant commissioner of the United States Fish Commission in charge of Pacific operations. He maintained that there were no separate strains or subspecies of salmon. ${ }^{47}$ To Stone, a chinook was a chinook. He admitted at one point that he was totally confused by the behavior of Pacific salmon, because they did not conform to his expectations from his association with Atlantic salmon. When Stone examined anadromous fish on the West Coast, he interpreted their behavior according to eastcoast experience. Stone "viewed western nature through eyes trained in the East. $\mathrm{He}$ saw Salmo, not Oncorhynchus." ${ }^{, 48}$ Not until biologist Willis Rich's 1939 article contending that each run was could be a subtly different subspecies did science recognize this possibility. With their incomplete observations, Stone and Hume typified science's hazy picture of Pacific salmon and the unwarranted faith society put in hatcheries to maintain fish runs.

This lack of accurate scientific information allowed fish managers to believe that their techniques were more efficient than nature's. Fish biologists assumed that hatcheries would be more efficient in producing salmon than natural spawning, and with reason: hatchery technicians spawned nearly ninety percent of captive eggs into 
fry, as opposed to less than ten percent hatched in the wild. ${ }^{49}$ This initial achievement led some to wild predictions of success for full-scale hatchery production, with the ultimate result in the minds of some of removing all salmon spawning from risky nature to the safe, efficient confines of the hatchery.

Many of the biological pitfalls that modern aquaculture recognizes and contends with were unforeseen by fish managers of nineteenth century hatcheries, when the big push to build hatcheries was on. Besides structural problems such availability of broodstock, availability of clean water, spring freshets that destroyed primitive hatcheries, and lack of money, there were organic problems, many that contribute to the degrading of runs today. Hatchery fish tend to spread disease. Because they are raised under artificial conditions, spending a great deal of time in unnaturally high concentrations of fish, they contract and spread any number of diseases, such as bacterial kidney disease.$^{50}$ Many of these fish must be treated with hormones and antibiotics as juveniles to contain infection. When these fish are released they spread disease to wild populations.

Hatchery fish do not survive as well in the wild, yet because of their numbers, they out-compete wild fish for food. ${ }^{51}$ In addition, these huge numbers fish artificially inflate the total number of fish in the fishery, which raises the quota of "catchable" fish. From this inflated number of available salmon, an inordinately large percentage of wild fish are caught.

The science of genetics raised other concerns. For some undetermined reason, fish from hatcheries lack the strong homing instinct of wild fish and do not 
always return to their natal river or hatchery. Biologists are not sure whether hatchery fish genetically have a harder time finding their natal stream or whether hatchery practices, such as releasing the fish into a river before they have had the time necessary to imprint upon the stream. In any case, geneticists theorize that this increases the chances that hatchery fish with weaker, more limited genetic backgrounds could mate with wild fish from an entirely different river system. (It must be said that a certain amount of straying is natural to salmon. In prehistoric times it would have been the only way that salmon could colonize other rivers and streams, or recolonize streams where local extinctions had occurred. $)^{52}$

In short, the millions of domestic salmon released into the environment compete with wild salmon for food, spread disease, skew the catch quota, and potentially dilute the genepool. ${ }^{53}$ These are now reasonably understood phenomena today. But in the 1890 s, they were mysterious and confounding.

Compounding the lack of scientific understanding that hurt fish populations with poor management was that even when science operated with reasonable information about salmon and their habits, it was politics, not science, which drove decisions about the construction and operation of hatcheries. Political pressure from commercial and sport fishing constituents to use hatcheries to keep the fishery in fish influenced fish managers. By the 1890s, the United States Fish Commission had developed into a bureaucracy whose decisions became based on production values rather than scientific observations of success or failure. ${ }^{54}$ Within this framework of compensating for the damage done to spawning grounds caused by development of 
resources in the interior and replacing the fish caught in the lower river, there was precious little room for the biological needs of salmon. The politically driven machinery of wholesale salmon production had a great impact on wild salmon stocks, and thus helped impel anadromous fish toward decline. Unaware of these effects, salmon managers plunged ahead. According to Willis Rich, hatcheries "probably inflicted as much, or more, damage to the salmon runs as they did service of value." 55

This has become a rather tedious list of failures in the struggle to bring salmon back from the brink of ecological collapse. The point here is that hatcheries obviously did not reverse the decline of runs in the nineteenth century or early twentieth century. In the 1940s, the promise of progress that was applied to the river began to be applied to hatcheries, upgrading the hatchery process from several small, inconsistently operated hatcheries to state-of-the-art facilities operating with more substantial budgets in an institutionalized framework. The value of wild salmon runs was not yet understood or acknowledged by scientists, and the newer hatcheries did not help wild runs any more than the nineteenth century hatcheries.

The role of hatcheries to offset overfishing and upstream development was expanded to include the replacement of fish killed at the big federal dams. Biologists dreaded the impact of Bonneville Dam, because no fish-ladder like Bonneville's had ever been tested and they feared that even with fish-passage systems there would be a large adverse impact on migrating fish. Recognizing the potential for loss, Congress passed the Mitchell Act in 1938. This act aimed to "facilitate conservation 
of the fishery resources of the Columbia River and its tributaries" by providing for irrigation screens, fish ladders of future dams, and the construction and operation of fish hatcheries. ${ }^{56}$ The Corps built many of these hatcheries just upstream of Bonneville Dam and many more in the lower Columbia. They were operated by the state fish and game agencies. ${ }^{57}$ By locating the Mitchell Act hatcheries on the lower Columbia, fisheries managers neglected the upper river runs which were hurt most by the dams. From an engineering standpoint, this made complete sense: it was far more efficient to release hatchery fish downstream from destructive dams so that fish would never have to cope with them. But Fisheries managers and engineers, in effect, ignored two basic facts. The first was the biological fact that each run of fish up each tributary had evolved as part of that ecosystem, and that each tributary's flora and fauna depended on them. The second fact was the historic dependence of Indian fishers on these runs. Engineers disregarded human and natural history in order to achieve greater rational efficiency.

This began the connective relationship of dams and hatcheries. Thus the term "mitigation" has always meant hatcheries, and has always referred to dams. Other proposals to assist salmon, such as barging them around dams or drawing down dams to facilitate migration, are not included in that term. Mitigate meant infusing the river with young salmon against the effects of the dams. They were not intended to address the disappearance of habitat, except where habitat was destroyed by the dams themselves. ${ }^{58}$ This distinction may seem trivial at this point, but it is important to understand because terminologies, like everything else in Columbia Basin salmon 
politics, are subject to confusion and strife. For a bureaucracy, exact language is important. If mitigation means a specific tactic at a specific place, and that definition is accepted by all political and scientific bureaucracies involved, then to change that definition can prove very difficult. Bureaucracies are not known for supple adaptation to change. When the Northwest Power Planning Council redefined the term "mitigation" in 1982 to apply to salmon and steelhead restoration projects in Columbia subbasins, "off-site" from the hydroelectric projects that caused the damage, it found that the bureaucracies that run or the industries that rely on the river as an engine of commerce did not fully accept its new definition.

The Umatilla River Basin became eligible as an appropriate subbasin for an off-site mitigation program with the advent of the Northwest Power Act. And with that eligibility, hatcheries entered a new phase. While acknowledging the past abuses of hatchery-based management and the present dangers of hatchery fish, the Northwest Power Planning Council did not abandon the use of hatcheries. In 1982, the Council simply tried to use them more judiciously. The Council also provisionally accepted the Tribes' concept of "supplementation," even though this technique has drawn criticism from biologists who worry about mixing hatchery and wild stocks of fish. Technically, the Umatilla Fish Restoration Program is a supplementation program. For the sake of clarity, in order to distinguish the Umatilla Program from the projects the Yakama have initiated, this paper describes two types of modern hatchery management: supplementation and restoration. 
Supplementation is a technique that places fish in a stream where salmon and steelhead runs are distressed. While most fish released from hatcheries are put into the river with the idea that returns will come back to the hatchery, supplemented fish are planted in the river where it is hoped they will return and breed naturally with the wild fish, because they are from native broodstocks. Until very recently, hatchery technicians were not particular about from where their broodstock came. The run of fish collected for broodstock might come from a river system far away and have few of the genetic characteristics similar to the local, native fish. Earlier attempts at hatchery propagation failed to recognize the genetic damage this could cause. But supplementation is meant to take all existing biological knowledge and the genetic characteristics and try to augment numbers in a fragile area to build the existing run up, rather than try to replace a native run with a hatchery run. Biologists choose broodstocks from areas geographically and genetically close enough to the supplemented river, enough that the genetic requirements are extremely similar. ${ }^{59}$ Restoration is an approach that reestablishes salmon runs to a river or stream where salmon have been absent. Just as with supplementation, the choice of broodstock is important; obviously it cannot be the original genetic material. Fishery managers want a fish that is as close as possible a match to the original, extinct fish. Preferably, managers acquire broodstock from a stream nearby with a genepool very similar to the run under restoration. Restoration is the technique the Tribes used on the Umatilla. ${ }^{60}$ 
Hatcheries have not stopped or reversed the decline of anadromous fish. They were never intended to preserve wild runs: on the contrary they were to replace them. Nineteenth- and early twentieth-century fish managers used hatcheries with no consideration of natural spawning, wild fish. They operated their hatcheries as fish factories, where they simply produced volumes of "meat" that would end up caught in the lower Columbia or at sea by commercial or sports fishers and thus provide a service of value to those fishers. Hatcheries operated under political considerations inconsistent with modern biological goals. ${ }^{61}$

This, then, begs the question: if hatcheries have been, by and large, a failed management tool, why should the story of a fish hatchery interest us? Why should this new hatchery suddenly be successful? The answer is that this restoration attempt is taking place under unique circumstances. The Tribes are using newer hatchery techniques and using them in a way never before envisioned. The Umatilla Program shows us a clear instance of the Tribes using the best scientific information available to take control of their restore their river. The Program it is an example of what can be accomplished with the cooperation of traditionally hostile agencies, like the Oregon Department of Fish and Wildlife, and in spite of hindering bureaucracies.

\section{Hext}

\section{Indians and Hatcheries}

If the relationship of Indians to salmon is complex and rich in tradition, then the relationship of Indians to hatcheries is downright complicated and fraught with 
disputed science and divisive politics. Native Americans have turned to technology to restore a river and its salmon degraded largely by non-Indians' use of technology. As Indians use hatcheries, they confront a scientific community that, although a party to the unrestrained dependence on hatcheries for over one hundred years, has come to view hatcheries dubiously. Many non-tribal biologists and environmental groups have questioned any continued reliance on hatcheries. Non-tribal river managers and biologists have concluded within the last decade that the overall effect of hatcheries on the fishery has been disastrous. The Tribes counter that they are using hatcheries as a tool in a much different fashion than state fish and wildlife agencies have traditionally used them and therefore the Tribes should proceed. ${ }^{62}$

These new hatchery programs are much different from the traditional EuroAmerican hatchery programs. ${ }^{63}$ They rely on a strategy that the Northwest Power Planning Council's Columbia River Basin Fish and Wildlife Program in 1982 called "reprogramming."

There are two aspects to this idea of reprogramming the Columbia's manmade salmon runs. The first concerns the locations of hatchery releases into the river. ${ }^{64}$ In the 1940 s when the Mitchell Act hatcheries were first implemented they focused on the lower Columbia. The Army Corps of Engineers and fish managers established the existing hatchery system where it made good engineering and economic sense: if dams hurt salmon and steelhead why make fish in places where those fish would have to pass many dams? But this helped only lower-river fishers and ignored the tribal fishery. The Council's reprogramming of the hatchery system 
would augment and not ignore salmon populations in the middle and upper river system.

Reprogramming also refers to changing the way the Tribes operate the hatcheries themselves. Tribal hatcheries are built on the "gravel to gravel" concept. Natural ponds hold juvenile fish to acclimate to the new "natal" stream, and where biologists hope these fish will come back to spawn naturally. This differs from older style "meat" hatcheries, hatcheries which are only concerned with pumping large quantities of fish into the fishery, where fish reared in concrete pools return exclusively to the hatchery and are spawned artificially by man. For example, the Shoshone-Bannock Indians use in-stream boxes to incubate eggs directly in the river. This alleviates the need to raise the salmon in cement tanks. ${ }^{65}$ Then, when these salmon return, biologists hope as many fish as possible spawn in the gravel of their home river, where they were acclimated, even if they were spawned in a hatchery. The Tribes' hatchery policy recognizes that salmon and steelhead that leave a hatchery merely to return to that hatchery does not mimic nature. Rather than perpetuate a policy of meat hatcheries at the expense of the environment, Indians are promoting a more natural system.

Reprogramming the rivers to mimic upper river salmon runs is fundamentally different from the totally unnatural way traditional hatcheries functioned. It is also far from the position of several environmental groups that fish managers cease all hatchery releases because of the potential damage hatchery fish can do to wild runs. This stance of the Tribes, right between agency fish managers and their factory 
hatchery techniques, and many environmentalists and their insistence on a ban of hatchery fish, is consistent with the idea that Indians are not environmentalists as we are familiar with the term. Rather, they are pragmatic managers with respect for the land and its animals. The Tribes have a cultural interest in having salmon return to tributary rivers and streams of the Columbia. It is important to them that their people be able to catch a fish in the river for both sustenance and ceremony. It is likewise important economically that their commercial interest on the mainstem be successful. By not being purists in the sense of despising hatchery fish versus wild, they have kept their management options open.

The Tribes watched as the Mitchell Act hatchery system failed to take the mid- and upper-Columbia areas into consideration. The Tribes gained ground in their attempt to challenge state and federal monopoly on hatchery, beginning with Judge Orrick's ruling in Phase II of U.S. v. Washington in 1980. In Phase II, the court ruled that the $50 \%$ share guaranteed by the Treaties included hatchery fish, even if those fish were reared by the states. Then, in 1982, the Council's interpretation of the Northwest Power Act opened the door for tribal projects that attempt to restore fish on or near the reservations by recognizing the need for a tribal role, and specifically by affirming projects on the Yakama and the Umatilla rivers.

Politically, the timing of Native American interest in hatcheries presented the authorities that run the river with an awkward situation. Hatcheries had fallen out of favor with biologists and environmentalists just as Indian peoples had acquired the political influence to change the emphasis fisheries managers put on the lower 
Columbia with the Mitchell Act hatcheries. Since the late 1980s, this has exacerbated feelings of animosity between white fisheries managers and the Indian tribes. The implementation of the Mitchell Act shows the degree to which fishery managers ignored Indian interests. By the mid 1970s, the Mitchell Act hatcheries, as they became known, were established almost exclusively in the lower Columbia, far from the mid-and upper-basin, where the damage from the dams was really taking its toll. For example, when the Army Corps of Engineers built John Day Dam it included two hatcheries in the blueprints, one the Oregon side and one on the Washington side. After the 1969 United States v. Oregon, in which Judge Belloni ruled that Indians were entitled to an "equal share" of the fish, the Corps moved those John Day hatcheries downstream, where they augmented the lower Columbia. The Corps gave no rationale, but this correlation between a court decision that recognized Indian rights to more and the elimination of an up-river hatchery suggests that fish and wildlife agencies were concerned not about the Indians, but downstream nontribal fishers. ${ }^{66}$

For decades fish managers saw fish culture as the centerpiece of salmon management. But when it came time to help the tribes with hatcheries, non-Indian biologists were now saying that every salmon run in most streams or stream systems was a discrete subspecies that should not be displaced by artificial propagation. Tribal biologists maintain that, while there certainly are genetic traits that appear in differing runs of fish, there far fewer separate runs than many biologists claim. This is the essence of the "splitters versus lumpers" debate, a scientific debate with 
political overtones. The splitters are those who divide stocks of salmon into everfiner distinctions and believe that all runs are subspecies not to be diluted with fish from other stocks. Lumpers are those who feel there are far too many such distinctions, that anadromous fish have much more in common genetically to one another-esentially, that "a chinook is a chinook"- and tend to "lump" all fish together. ${ }^{67}$

This turn-around by non-tribal biologists from whole-hog artificial production with undifferentiated stocks to a cautious, anti-hatchery attitude comes at the exact time that Columbia River Indians have settled on a strategy of using hatcheries to rebuild runs. This coincidence contributes to an overall attitude of mistrust by tribal fish managers. The Tribes have come to regard almost any attempt to advocate for wild fish, however well intended, as stalling and a disregard for their treaty rights. For example, tribal biologist Douglas Dompier argues that genetic diversity was merely a buzzword and an excuse not to act, and retain control over hatcheries. He maintains that the agencies responsible for salmon management have long excluded the Tribes from the decision making process. As biologists more fully understand the detrimental effect of hatchery fish on wild runs, the argument against the wholesale production of hatchery fish seems reasonable. But the Tribes, who had at one time agreed that wild fish were the way to go, have pushed now for any fish. Hatchery fish will do.

Characterizing the debate as between splitters and lumpers is an oversimplification. The two conflicting views on fish genetics, at its core a scientific 
issue, has become a political issue. The Tribes see these political arguments as a distraction from the source of the major cause of loss on the river. They see the big dams causing far more "genetic" damage than hatchery fish. The Tribes also see little similarity between traditional hatcheries that released huge volumes of salmon into the fishery, and their design of small, gravel-to-gravel hatcheries. It is the scale of the tribal hatchery program, not necessarily the hatcheries themselves, which alarms many noteworthy biologists. ${ }^{68}$ The Tribes have plans for many such supplementation hatcheries on many of the rivers in their ceded lands, including the Walla Walla and Grande Ronde.

In an article partially funded by Oregon Trout, four prominent biologists criticized the technique of supplementation (placing hatchery-raised salmon and steelhead side by side with wild fish in an attempt to bolster the natural stocks) as "not only...inconsistently defined, but so many methods and objectives are espoused as to make the term meaningless." The report questioned the aggressive use of supplementation programs without adequate scientific evaluation of the results. ${ }^{69}$ One such project is the Yakima River supplementation program, where hatchery fish are put into the Yakima basin right next to wild fish in order to encourage those hatchery salmon to return and interbreed with wild fish. This is exactly contrary to what biologists have been recommending in recent years, and the difficulty of addressing those concerns have hampered the Yakima Program and increased its cost substantially. 
In the Umatilla River story, these issues were absent because it is a restoration project. The biological hazards associated with hatcheries were greatly reduced because there was no original genepool to thin out. The Umatilla program does not augment a distressed wild population, it replaces non-existent fish. The problems of inter-breeding, straying and thinning of the genepool at-large, and competition with wild fish are of far less concern, though they are not totally eliminated.

In addition to genetic concerns, day-to-day hatchery problems persist: the availability of clean water or the outbreak and spread of disease. There is also-and this is especially true of the Umatilla-the very real problem of habitat. Hatchery fish will have no more luck in a dry river than did their predecessors. Fortunately for the Umatillas, the controversy over the appropriate hatchery strategy did not hinder their program. The Northwest Power Planning Council gave the Tribes the vehicle they needed to effect change, and they seized it.

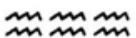

FOR 150 YEARS, COLUMBIA RIVER INDIANS have struggled to maintain meaningful treaty rights. For more than one hundred years, fish managers have used hatcheries as a primary tool in their struggle to maintain viable salmon runs. For the last twenty years, the Tribes have tried to wrest some measure of hatchery production from the monopoly of state fish and game agencies. They began to realize success with the Northwest Power Planning Council's Fish and Wildlife Program, 
which simultaneously solicited suggestions for rebuilding the salmon runs while expanding the concept of mitigation.

A minor event in 1992 highlighted the confusing and complex nature of the current hatchery controversy. The Oregon Department of Fish and Wildlife (ODFW) had a stock of chinook that had been scheduled for release from its hatchery on Lookingglass Creek. Due to concerns over genetic issues, ODFW decided to destroy the 800 salmon rather than release them. A group of Indians threatened to break into the hatchery and free the chinook in the Grande Ronde River so that they might spawn if ODFW did not release these fish. ${ }^{70}$ This event shows the ambivalence of the state's position: ODFW receives federal funds to operate fish hatcheries, yet indiscriminate dumping of hatchery-raised salmon put wilds stocks at risk. This situation where the Department's decision is ostensibly dictated by science is compounded by politics. ODFW's mission was to provide fish for its constituents, mostly sports anglers who pay a license fee for the privilege. But Indians do not pay state license fees; the treaties make them exempt from such regulations. Caught in a "Catch-22," the Department grows some fish in a hatchery, and then refuses to release the fish in Indian country on the stated grounds that the chinook could have an adverse effect on the genetic diversity of wild fish. Thus it appeared to Native Americans that ODFW's policy was motivated by a concern for its traditional constituents (non-tribal sports and commercial fishers), not for the tribal fishery. This kind of muddied policy succeeds only in breeding mistrust with the Tribes. ${ }^{71}$ 
The role of Native Americans in the Northwest salmon crisis takes the issue far beyond the stark, black-and-white positions taken between environmentalists and extractors, and makes it one of the most complex natural resource issues in the nation. Native Americans do not necessarily stand with environmentalists, but neither do they extract wealth in the way Euro-American capitalists do. Their traditional life of hunting and gathering was altered forever by the white invasion of their land. With growing recognition of their legal rights, the Umatillas have taken advantage of statutory changes in the hydropower system in order to restore their river and their cultural center.

The spiritual character of salmon to Indians may seem compromised in the face of hatcheries. Can one have a spiritual relationship with hatchery-reared fish? But the issue is not so narrow as hatchery versus wild salmon. The Umatillas are striving to rehabilitate a landscape that they have always revered. Salmon were historically a part of that landscape. They have done more than just make hatchery salmon. They have restored long-abused streamsides to enhance salmon (and thereby, many other animals') habitat. For a people to have a spiritual relationship with the land, the land must be healed first, by almost any means. But to heal the land, the Umatilla Indians had still to overcome the federal bureaucracy that operated the hydropower system: the Bonneville Power Administration. 


\section{CHAPTER III-THE SEMANTICS OF CONSERVATION: IMPLEMENTING THE \\ UMatilla River Fisheries Restoration Program}

Liberated reason can reveal what a river or a valley needs for its own realization, what values it may have beyond serving as a means to profit or amusement, what moral claims it makes on humans.

-Donald Worster ${ }^{1}$

$m m m$

With the Northwest Power Planning Council's adoption of the Columbia River Basin Fish and Wildlife Program, the Umatilla River stood on the threshold of change. Everything necessary seemed to be in place: the statutory framework establishing salmon restoration as a priority in the Columbia River Basin, the partnership of will and expertise needed for such an undertaking, and the money required for expensive rehabilitation.

Passage in 1980 of Northwest Power Act tied the generation of hydroelectric power to the health of anadromous fish runs, and explicitly made salmon and steelhead equal partners with the hydropower system. The Act instructed the Council not only to halt the damage dams were doing to salmon runs, but also to reverse the damage. This repair-work to the runs was not confined to swapping live hatchery salmon for losses attributed to hydropower on the mainstem: the Act recognized that the Columbia and its tributaries should be treated "as a system," and that habitat enhancement was an inseparable part of restoration. ${ }^{2}$ In order to fund this restoration, 
the Act instructed the Bonneville Power Administration to pay for all mitigation efforts recommended by the Council.

The Act, in effect, meant that Bonneville must expand the reasons for its existence. After 1980, it became legally responsible for funding fish mitigation and restoration projects on a massive scale. But individuals can read statutes many different ways, and accordingly can control how a bureaucracy responds. It became clear to observers of the Umatilla program that Bonneville's Fish and Wildlife Division was stalling its implementation. One key to figuring out BPA's resistance to the program is in the type of language that its agents used in the dialogue between Bonneville, the Council, and the Tribes. By examining Bonneville's language we can get a glimpse of Bonneville's rationale for stalling and trying to kill or control the program. Language is important because through it we can understand that this agency, charged with funding what would become the most expensive wildlife restoration effort in history, was not proceeding in a frame of mind desirable for achieving biological goals. An examination of the language Bonneville used in its correspondence with the Tribes and the Council shows that individuals within BPA's new fish and wildlife division at were operating from within the realm of the costbenefit analysis. These bureaucrats had great difficulty adjusting could adjust to a world where biology was equal to engineering. 


\section{H}

\section{New Alliances and a Bold Plan}

Even before passage of the Northwest Power Act, the Tribes had worked to patch together a fragile alliance between traditional enemies. By the late 1970s, CTUIR had brokered tentative agreements to study fish prospects in the region with all the federal, state, and local entities that could influence salmon restoration in the Umatilla River: the U.S. Bureau of Reclamation (which had built the infrastructure used by the irrigators), the U.S. Forest Service (in whose territory the Umatilla's headwaters lie), the Oregon Department of Fish and Wildlife (the state agency responsible for hatchery management), the four local irrigation districts (the organizations that had bled the river dry), and the Bonneville Power Administration.

Three things came out of this initial affiliation. First, CTUIR acquired funding from BPA to conduct research on fish passage in the many irrigation diversions on the Umatilla. Second, a cooperative effort by local chambers of commerce, irrigation districts, fishery experts from the Tribes, and the state and federal governments supported the Bureau of Reclamation's instream flow study, which would examine how more water could be brought to the river. Third, the United States Fish and Wildlife Service issued a BPA-funded study on the existing supply of water flowing through the Umatilla Reservation and how this water might accommodate a fish hatchery. Under the impetus and leadership of the Confederated Tribes, there seemed to be a new consensus dedicated to the idea of returning salmon to the barren Umatilla. ${ }^{3}$ 
Striking among these relationships was the new alliance between ODFW and CTUIR. Historically, states and Indian tribes had opposed one another over fish policies, and the federal courts had resolved these conflicts. The legal record, from United States $v$. Winans, to United States v. Oregon, to the Boldt decision, demonstrates clearly that states have been in contention with Indians over treaty rights to fish since the nineteenth-century. ${ }^{4}$ The Northwest Power Act instructed both the Council and the BPA administrator to "encourage the cooperation, participation, and assistance of appropriate Federal agencies, State entities, State political subdivisions, and Indian tribes" in order to facilitate the Council's plan. ${ }^{5}$ The State of Oregon showed unprecedented cooperation in working through its fish agency, the Oregon Department of Fish and Wildlife, to help the Tribes establish a fish hatchery system. ODFW assisted by drafting the report describing the project. ${ }^{6}$ It also gave technical help in the actual building of the hatcheries and training tribal personnel in hatchery operations.

At first, ODFW and CTUIR decided that a single small-scale facility to supplement the last wild steelhead in the basin would best suit the Tribes' long-term goals. Their decision was based primarily on the limitation of funds available before 1980. With the passage of the Power Act in 1980, their vision broadened. The Tribes presented a plan to the Council that showed a series of facilities scattered across the basin. These facilities would de-centralize the hatchery process, with different facilities that could collect, transport, hatch, and rear salmon and steelhead, allowing 
more time for the juvenile fish to imprint on their home streams and improve their rate of return.

The plan created by the Tribes and ODFW was a remarkable blend of technology and nature, an idea attempted in the past but unsuccessfully. What made the Umatilla Fish Restoration Program unique was that these new hatcheries would not be "meat" hatcheries. These new fish would not be factory fish, generic salmon merely adding to the total numbers of fish in the fishery the way that the Mitchell Act hatcheries in the lower-Columbia had done. Tribal fish technicians would recapture some fish at an adult holding facility built at Threemile Dam and artificially spawn them for broodstock, but they would allow most of the strongest salmon—and this is what made the Umatilla program so unique— to remain in the river, to swim upstream into the tributaries and spawn naturally. Fish managers would rely on nature, not the hatchery, to propagate most of the salmon in the basin. Also included in the program were screens for irrigation ditches, and stream restoration to repair the degraded river, passage facilities at the small irrigation dams at Echo and elsewhere. The Confederated Tribes and ODFW planned reintroduce salmon to the waters of the Umatilla.

If the strategy of rebuilding the Umatilla runs through a combination of natural and artificial means was unique in the United States, so was the technique. The Umatilla program was different from orthodox hatcheries in several respects. It was decentralized. Dispersed throughout the Umatilla and its tributaries were five or six different facilities for holding and spawning adults, pools for growing fry, and 
ponds to acclimate juveniles. Because the system was based on restocking the basin with fish that would spread throughout the basin and spawn naturally, it was necessary that the fish not be spawned and reared at a single site. A typical meat hatchery has a weir extending across the stream up which the fish travel. The weir prevents all fish from swimming any farther upstream. The fish are guided up a short ladder and into a concrete pool where they mill around until technicians decide to spawn them. In the Umatilla Program, adults are collected at Threemile Dam, but they are spawn and fry are reared at facilities far upriver on the reservation: at Thorn Hollow, Gibbon, Meacham Creek, or Minthorn Springs. After the fry get to a specific size, they are placed in a pond with a natural bottom at Bonifer Springs on Meacham Creek, the main tributary of the upper Umatilla. There they grow into smolts, imprinting on Meacham Creek for their eventual return trip.

When the Council adopted its Columbia River Basin Fish and Wildlife Program in 1982, it made special mention of the Umatilla in a subsection entitled “Construction of Major Hatchery Facilities." Section 704(i)(1) stated that Bonneville shall fund the Confederated Tribes of the Umatilla Indian
Reservation to design, construct, operate, and maintain juvenile release
and adult collection and holding facilities on the reservation.....Bonneville
also shall fund the construction of a facility to increase the existing
hatchery production to provide for an additional 200,000 summer
steelhead smolts for release in the Umatilla juvenile release and adult
collection and holding facilities.

With this firm if unspectacular statement, the Council officially backed the Confederated Tribes' plan to resurrect the Umatilla River. It seemed as though the 
Council was wasting no time implementing the parity promise. ${ }^{8}$ Each individual component was small in scale. Yet taken together, this system comprised a largescale and ambitious project. Nowhere else in the United States have humans restored naturally spawning salmon runs that were once extinct.

In 1982, the Council endorsed this plan devised by the Confederated Tribes and Oregon Department of Fish and Wildlife . But the Tribes sensed a bureaucratic inertia that plagued projects like theirs. Many times in the past, there would be much talk, promises made, but nothing had happened. Therefore, the Confederated Tribes decided on a "proactive" approach, even if it was highly controversial. Tribal members acquired a number of tule chinook from a federal hatchery down the Columbia. Tules are type of fall chinook far less desirable to commercial fishers because they bring less at market. (The stock the Tribes originally wanted was denied them at first by the National Marine Fisheries Service because NFMS did not consider the Umatilla a candidate for a "terminal fishery" due to the poor condition of the river.) The Indians released these fish into the river and announced to Bonneville that there would be adult salmon coming up the Umatilla around $1988 .^{9}$ This was an audacious move. By acting unilaterally, the normally cooperative Umatillas risked alienating their irrigating neighbors, BPA, and worst of all, the Council. BPA did indeed resent this move, but it was helpless. ${ }^{10}$ In four years chinook would return to the river. If the Council, BPA, and the state government did not address the issues of water allocation on the Umatilla— the very issue that had killed off the Umatilla runs in the first place-then there would not be a river for 
them to ascend. A potential public relations disaster faced fish management agencies: the spectacle of huge salmon stranded at the mouth of a non-existent river. Such a scene was not in the State's, the Council's, or Bonneville's best interests. It is important to note that this was out of character for the Confederated Tribes. Their typical method of dealing with the river establishment was to "negotiate rather than litigate," and they did so with infinite patience. ${ }^{11}$ They did go back to that strategy in the struggle to re-water the river. It was a curious deviation from the Tribes' method of operation, justified in the minds of the fishery as necessary to force past what the Tribes' saw as the typical sluggishness of bureaucrats who tended to discuss a problem ad nauseum before taking any action.

In 1983, the Tribes and ODFW formally submitted to the Council and BPA their request for funding the first Umatilla project, the Minthorn Springs holding facility. ${ }^{12}$ This was the first critical point. Here was a project, which had the highest priority of the Northwest Power Planning Council. Bonneville had approved and funded its preliminary planning. State fish and wildlife experts agreed that it would be highly beneficial to salmon in the Columbia Basin. But just as it was ready to begin the purchase and construction stage, at this critical point that the Bonneville Power Administration-which had funded and endorsed the program's studies, which the Northwest Power Act now required to fund the construction of the program—balked. BPA began, through a series of confusing maneuvers, to avoid paying for this revolutionary project. 


\section{Cost-Benefit versus Cost Effective}

From the time of its creation in 1938, the Bonneville Power Administration marketed the power generated by the big dams on the Columbia and Snake Rivers to pay back the federal treasury for the system's construction costs. ${ }^{13}$ In the American engineering tradition of total rationalization, the water of the entire basin was harnessed for the "multiple uses" of people: hydropower, irrigation, flood control, and transportation. ${ }^{14}$ Even the Columbia's headwaters were not immune. A 1961 treaty encouraged the Canadians to build reservoirs in Canada to control the Spring freshet in exchange for hydroelectricity. ${ }^{15}$ Engineers secured virtually every drop of the river's water for the use of humans.

In 1980, Bonneville's burden changed. The Northwest Power Act required BPA to fund all fish mitigation efforts endorsed by the Northwest Power Planning Council. Bonneville had funded various fish and wildlife studies in the Columbia River Basin, but it had never given funds to any series of projects on the vast scale that the Northwest Power Act anticipated.

Bonneville began to resist funding the Minthorn Springs acclimation facility and the Tribes and ODFW entered into a struggle with Bonneville over the program. This struggle is very confusing but highly instructive, especially if we understand a little of the history of Columbia River development. This bureaucracy, so accustomed to operating the river as a machine, was uncomfortable its new role facilitating fish mitigation. ${ }^{16}$ The ultimate nature of this struggle revolves around 
perceptions of the river, and the language that agencies use to describe those perceptions. Up until 1980, efficiency was foremost in the minds of engineers. The Northwest Power Act challenged the notion of the river as an efficient machine.

This chapter stresses the difference between the two terms "cost-benefit analysis" and "cost effectiveness." While seemingly a question of semantics, the differences between these terms and the way river managers used them, are actually charged ideologically. "Cost-benefit analysis" is a term of engineers and urban planners, examining the comparative worth of new infrastructure and deciding based on that comparison whether to construct such improvements. "Cost effective" is a term that, in Columbia River salmon restoration, refers to projects already accepted, where the issue is not whether to build, but which is the least expensive way to build. On the Columbia, the old terminology represents a system in which hydropower is considered superior to salmon, whereas cost effectiveness, with its primary emphasis on accomplishing biological objectives, works to promote the Northwest Power Act's demand for equity. As will become clear from the letters, memos, and reports issued by Bonneville during this period, BPA clearly was still rooted in the old way of running the river.

Up to this point, debates on the impact of development projects on Columbia River salmon in the Basin were conducted in the language of the cost-benefit analysis. Cost-benefit analysis is a method of examining a project's financial viability by comparing monetary costs against its monetary benefits. It is a completely rational tool for gauging whether public works projects warrant the 
expense. In the case of projects with effects on wildlife, however, there is a problem. The biological needs of an ecosystem do not conform to an engineer's measurements. In other words, they cannot be evaluated mathematically. On the Columbia and Snake, the engineers' rational decisions did not favor salmon. Unfavorable cost-benefit analyses did stall some of the dams for as much as ten years, but never because salmon were part of the unacceptable cost. Ultimately, once the era of building the big dams commenced in 1938 with Grand Coulee and Bonneville, the U.S. Army Corps of Engineers built every big dam that was part of its "308" report, except Asotin on the Snake. ${ }^{17}$ By the late 1970s, most wildlife managers had accepted that the methodology of cost-benefit analysis was "inappropriate" when dealing with fish mitigation. ${ }^{18}$

There are three principal reasons why cost-benefit analysis is an erroneous and obsolete approach to management of the Columbia River. The first is the difficulty of attributing a dollar value to biodiversity. Salmon are exactly in the middle of the riparian and oceanic food webs as both prey and predator. They are a critical food source for seals, sea lions, orcas, bears, osprey, eagles, other fish, and humans. In addition, there are the trillions of insects and microorganisms at the base of the food web that depend on the biomass of many millions of pounds of dead salmon in the arid environment east of the Cascades, breaking this protein down further into basic nutrients for the ecosystem. So too the salmon's offspring-fry and fingerlings-need the insect life attracted by the carcasses of their parents as nourishment to survive and to become prey for other creatures. It is impossible to 
gauge this enormous biological wealth of salmon, living and dead, in terms of dollars. ${ }^{19}$ Since no dollar value can be ascribed here, there must be a blank in that column of the cost-benefit analysis. In rationalized economic terms, the wealth that contributes to the well being of several ecosystems simply does not exist.

Cost-benefit analysis also cannot measure the cultural and religious value of salmon to Columbia River Indians. The Treaty of 1855 between the United States and the Walla Walla, Cayuse, and Umatilla peoples recognized the ceremonial and subsistence value of salmon. Court decisions have upheld this Treaty. ${ }^{20}$ While the economic importance to the Tribes of salmon restoration was addressed by the Boldt decision, the full necessity of salmon to native peoples cannot be conveyed in a costbenefit analysis since there is no way to measure economically the spiritual value of salmon. ${ }^{21}$ Ignoring this spiritual connection amounts to impeding the Treaty Tribes' free exercise of religion. Nonetheless, federal agencies have tried to create some basis for measurement. In a 1984 letter, the National Marine Fisheries Service, in rejecting the Tribes' request for young fish with which to start their hatchery, wrote:

A difficulty in determining economic values lies in a lack of evaluation techniques that describe monetary benefits for Indian ceremonial and subsistence fisheries and the social well-being of the CTUIR. We realize that there are attributes of a BR [Bureau of Reclamation] flow project that benefit the CTUIR goal of a terminal fishery on your land. There simply is not a way for us to assign monetary benefits to the BR project for meeting this goal. If you have any suggestions on how we may assign economic values to such ceremonial and subsistence fisheries, we would greatly appreciate hearing your views. ${ }^{22}$ 
By referring to the spiritual aspect of salmon as ceremonial, NMFS showed that it was either ignorant of the connection between ceremonial and religious or that it simply did not care. In any case, this is no different from asking a Jew how much the Wailing Wall in Jerusalem is worth, or a Catholic the value of Holy Communion, or a Baptist the cost of his prayer. It graphically demonstrates how bureaucrats, within the framework of their language, pursue policies that can undermine the cultural rights of native peoples.

It is difficult to argue from a purely economic point of view, with the salmon fishing industry a shadow of what it once was, that rehabilitating salmon runs is worthwhile. In the absolute economic terms of a cost-benefit analysis, engineers are justified in trading-off the greater wealth produced by the dams in versus the extinction of the salmon fishing industry. But this lumping of local economies into a single regional formula has, according to William L. Lang, "effectively homogenized space by making economies unidimensional." Each community on the river had its own economy based at least in part on when and where the salmon ran and where they were caught. Cost-benefit analysis looks only at proscribed economic measurements to determine total overall wealth. It is incapable of examining the equity of what is lost. ${ }^{23}$ It does not take account where losses occur and how they affect those local communities. Because salmon fishers on the lower river are not going to become aluminum factory owners or dam engineers or construction workers on the mid- and upper-Columbia River dams, those fishers suffer a net loss. Costbenefit analysis reduces local economic losses to a set of numbers, and ignores the 
resulting social costs entirely. Similarly, the social values ascribed to the biodiversity of salmon populations are nonexistent. In 1980, the Northwest Power Act codified these values into law. This inherent inequity in cost-benefit analysis is precisely why it is incompatible with the Northwest Power Act and its promise of parity. ${ }^{24}$ While many would argue that cost-benefit analysis has a place in Columbia River management, it is inappropriate when dealing with projects that have biological rather than monetary goals.

The idea of moving away from cost-benefit analysis concerning biological imperatives was not new with legislation like the Northwest Power Act. In 1958, The Fish and Wildlife Coordination Act altered the perception of fish and wildlife managers. The legislative history of the Coordination Act states "cost-benefit justification of fish and wildlife measures is both unnecessary and undesirable." While the Coordination Act in itself has not succeeded in defending fisheries from development projects, in it Congress' debate laid the intellectual and political groundwork for the rejection of cost-benefit analysis from the discourse. ${ }^{25}$

The emphasis of the Northwest Power Act is not on new development, but on mitigating the biological impacts of old development. Because of the Act's positive instruction for such mitigation projects, there is no element of should or should not build based on economics. NPPC-affirmed projects will be built. The issue is not if, but how. To gauge the costs of projects that have biological goals rather than economic ones, fishery managers require a different method. For the new construction of the fish enhancement projects set forth by the Columbia River Basin 
Fish and Wildlife Program, the method biologists use is a "cost effectiveness" or "least cost" method. That is, out of a given set of options, the cheapest alternative is permissible, so long as it follows the sound biological objectives set forth in the Council's Fish and Wildlife Program. Clearly, the cost-benefit analysis was no longer the determining criterion of fish and wildlife policy. ${ }^{26}$

What is potentially confusing about the historical record is that BPA does not use the term "cost-benefit analysis." Those words never appear together. Rather, it uses the term "cost effectiveness," which after 1980 became the politically correct term. Yet when looking at the record, there is a consistent pattern of BPA's Fish and Wildlife Division interpreting data as if it was using a cost-benefit analysis, not a least cost or cost effective method. This is evident in the way that BPA discussed the funding of projects. If the Fish and Wildlife Division had truly been using least cost, then it might have come up with alternate strategies for the Tribes and ODFW to pursue the biological goal of bringing salmon back to the Umatilla River. But what actually appears in the record is quite different. BPA consistently interpreted cost effectiveness to mean "benefits should equal costs," not "benefits by the least cost." ${ }^{27}$ By effectively hiding behind the words "cost-effective," BPA ignored the spirit of the Northwest Power Act while following its letter. Using this model, BPA would not have to fund any project that did not meet its expectations. 


\section{tetex}

\section{The Struggle for Control}

From the beginning in 1980, it was clear that BPA was slow to adapt itself to the Northwest Power Act. Its attitude shows in the language it used in a press release from that same year commenting on a spill of water intended to speed salmon smolts' trip to the sea. This communiqué lamented that "[t]his week power dams on the Columbia River will waste more water than usual," expressing the view that water allocated to salmon (indeed, all water "unused") instead of hydropower or irrigation was without worth, that resources diverted for the benefit of fish was squandered. $^{28}$

When Bonneville did adapt to its new task, it created its own Fish and Wildlife Division. The Northwest Power Act states that the "Administrator" of BPA

shall use the Bonneville Power Administration fund and the authorities available to the Administrator under this Act and other laws administered by the Administrator to protect, mitigate, and enhance fish and wildlife to the extent affected by the development and operation of any hydroelectric project of the Columbia River and its tributaries in a manner consistent with the plan... and the purposes of this Act. ${ }^{29}$

In addition, Bonneville "and other Federal agencies responsible for...operating" hydro projects in the basin 
shall...exercise such responsibilities, taking into account at each and every relevant stage of the decisionmaking processes to the fullest extent practicable, the program adopted by the Council under this subsection. ${ }^{30}$

BPA was also to "consult" with the U.S. Department of the Interior, NMFS, the state fish and wildlife agencies, the Tribes, and the operators of federal and non-federal dams. This instruction implied a new level of involvement that BPA had to meet. Ostensibly, the purpose of BPA's new Fish and Wildlife Division was to coordinate the expert resources to make the Council's the Fish and Wildlife Program function. ${ }^{31}$ However, its actual function seemed to be to protect ratepayers' investments in the Fish and Wildlife Program by making sure they were cost effective. With regard to the Umatilla River program, this division had a different agenda. ${ }^{32}$

Up until 1982, BPA had enthusiastically supported the ideas put forward on the Umatilla River. That year, the Council adopted the Fish and Wildlife Program with the Umatilla program as a part. ${ }^{33}$ But that November, after the formation of its new Fish and Wildlife Division, BPA balked. First, Bonneville requested that the habitat study of Northeast Oregon watersheds include the projected numbers of fish that could be hypothetically produced by each separate habitat improvement over the entire study area, about fifteen thousand square miles. CTUIR responded that a study of this size was unreasonable. Beyond the erroneous assumption that these complex variables could be computed to a formula that could mathematically calculate how each stream improvement could benefit the whole system, it was also economically unfeasible: CTUIR had nothing approaching the amount of money necessary to 
conduct such a study. Then, suddenly reversing itself, BPA agreed that the study was "not worth doing." 34 But this exchange highlights two consistent methods the Fish and Wildlife Division used to avoid dealing with the Umatilla program. First, that another study was needed. Second, that BPA needed numbers of hypothetical salmon (benefits) produced by these habitat improvements (costs) to justify Bonneville's expenditures.

In the spring of 1983, BPA informed the Tribes that the money for the first of the satellite facilities, Minthorn Springs, would be delayed until October of 1984two years after the Council had authorized funding that site. BPA said that the Tribes had "seriously underestimated costs of fish passage improvements" off the reservation. ${ }^{35}$ This referred to the second crucial piece to the Umatilla Program, retrofitting the old irrigation projects on the river to include fish passage improvements for diversion dams and installing screens for irrigation ditches. The Army Corps of Engineers completed original estimates of these costs in November 1982. At that time, the Tribes warned Bonneville that these estimates were no more than best guesses; the Council had not granted the Tribes funds to make these estimates. ${ }^{36} \mathrm{BPA}$ accepted the Corps estimates knowing they were rough and incomplete, but months later, BPA used them to delay the funds promised by the NPPC. At an August 1983 meeting requested by ODFW, BPA expressed its true concern to the Tribes and ODFW: would the Minthorn Springs facility succeed without improved streamflows? The Tribes convinced BPA that their biologists had 
a trap and haul plan worked out that would truck juvenile chinooks to the Columbia in times of low water. Bonneville appeared satisfied.

Nonetheless, in December after CTUIR had requested a progress report, Bonneville's Fish and Wildlife Division wrote that it could not fund the construction of the Minthorn Springs Facility because of "the numerous issues" that BPA felt were unresolved. For Bonneville, these issues meant that

$[u] n t i l$ the proposed Minthorn Springs facility is completely justified on its own merits or in terms of its contribution to an achievable overall plan, BPA will not provide additional design or construction funds. BPA cannot commit funds to projects that lack adequate technical documentation. To be acceptable for [BPA] funding, the Umatilla Basin restoration and protection projects must be consistent with recognized planning and budgeting processes so that cost-effective decisions can be made in a rational, timely and justifiable manner. ${ }^{37}$

This letter employs BPA's two chief methods of defending its refusal for funding. First, that more studies were required (“...projects that lack adequate technical documentation..."). Second, they required that the planning of any project must be "cost-effective." This became the theme of Bonneville's relationship to the Umatilla program until 1987.

During 1984, Bonneville continued to delay funding not only the Minthorn Springs facility, but also the Umatilla Steelhead Hatchery, another satellite facility and also a high priority for the Council. Because few steelhead are caught in the ocean fishery, a greater percentage of these fish come back to be caught by tribal fishers and non-tribal sport fishermen. This makes them very valuable to both the Tribes and the sport fishing industry. In order to fund the steelhead hatchery, BPA 
said it needed a comprehensive plan that stated its biological objectives. The Fish and Wildlife Division required that the study "[e]stimate potential benefits of each of the rehabilitation and flow enhancement projects, ${ }^{38}$ even though it is virtually impossible to estimate the cumulative benefit to salmon of each individual project.

Ed Chaney, the leading biologist for the Tribes, put it succinctly:

There is no substantive historical data on salmon production in the drainage; salmon have been absent in meaningful numbers for more than a half century. The number of hatchery fish ultimately "produced" in the Umatilla River will be determined by experience, management decisions and unpredictable political forces. The number of naturally-produced fish will depend as much on future management decisions as on the productivity of the habitat. No one will be surprised if a decade or two hence actual numbers of natural and hatchery-produced fish are $50 \%$ of today's projections. And no amount of ratepayer-financed study could meaningfully improve on estimates of production potential by tribal, state, and federal biologists. ${ }^{39}$

Chaney's words crystallize one of the most important debates between biologists and bureaucrats, not just in the Umatilla Basin, but over the entire range of the Northwest Salmon crisis: the uncertainties of modern ecology versus the absolute needs of fiscal planners. A natural system like a river basin has innumerable factors that affect its fauna. Some scientists once thought that it could reduce such an environment to a series of equations - that would define trophic levels of energy transference, for example -and discover hard numbers that planners could rely on. ${ }^{40}$ Planners could then use such numbers to see now much money would be required to produce " $\mathrm{x}$ " amount of salmon. But natural systems have proven far more impenetrable than scientists realized, especially in a system so damaged as the Umatilla River. 
Predicting such "production numbers" with any sort of accuracy is not only impossible, but also folly, because to predict and miscalculate is to disappoint and ruin credibility.

Tribal biologists believed that the Umatilla Fish Restoration Program would restore salmon populations in the Umatilla River Basin. They felt they had enough scientific evidence to support this position, and the Northwest Power Planning Council agreed. But the bureaucrats at Bonneville Power Administration wanted solid numbers of fish to show what it was paying for, that its expenditures were worth the price. Its preoccupation with what Chaney called "paper fish" shows that BPA was relying on a kind of cost-benefit analysis. But biologists cannot compute the program facilities times the stream improvements provide to equal a certain amount of fish. It is exactly these kinds of benefits, in terms of numbers of fish produced, that a project with over-arching biological goals cannot provide.

In 1985 and in spite of the difficulty, ODFW completed the comprehensive plan that BPA had requested. The Comprehensive Plan for Rehabilitation of Anadromous Fish Stocks in the Umatilla River Basin specified every aspect of the various projects, with attention to how many paper fish could be produced by every single satellite facility and every implemented stream-bed improvement, from flow enhancement to screens for irrigation ditches to passage facilities on the irrigation dams. ${ }^{41}$ BPA promptly informed the Tribes and ODFW that it wanted to request that the Council amend the Fish and Wildlife Program to include the Umatilla projects. Amending the Council's Program is a lengthy, arduous proposition. Doggedly, 
Tribal representatives reminded Bonneville that the Umatilla projects were already part of the Fish and Wildlife program, that they still had the highest priority of both the State of Oregon and the Council. BPA responded that there had been enough changes in the cost of the project to warrant the full amendment process, complete with input from the public. In addition, the comprehensive plan would have to be compared to other Columbia Basin fish mitigation efforts to assess the Umatilla's costs. This became BPA' Fish and Wildlife Division's third method of delaying funding. By claiming that the cost of the project had increased enough to justify reratification by the Council, BPA stymied CTUIR. To send the entire project back to the Council for review, because of the public participation and meetings, could easily take six months. $^{42}$

At a meeting on November 21, 1985, BPA repeated its desire that the measures be sent back to the Council. But it appeared that ODFW and CTUIR had convinced BPA that the financial hardship on the Tribes was too great. The Tribes could not afford to participate in the formalizing of the comprehensive plan, nor the six months it would take to amend the Fish and Wildlife Program. CTUIR also asserted that continued vacillating amounted to a violation of their treaty rights. BPA agreed to look at other procedures, such as submitting the comprehensive plan to the Council as a work plan, rather than a full amendment process, in order to get a statement of approval. ${ }^{43}$

This softening of BPA's position was temporary. In a letter dated January 7, 1986, the Director of the Fish and Wildlife Division wrote to the Tribes, informing 
them that since the overall costs of the various Umatilla projects were more than five times more expensive than originally planned, it was, after all, necessary to send them back to the Council for a full review. ${ }^{44}$ These so-called cost overruns that BPA was concerned about were the Army Corps of Engineers' preliminary estimates of retrofitting the irrigation diversion dams for fish passage. At the time, BPA had said, "not to worry." 45 Suddenly, it became a very large worry.

When ODFW and the Tribes further questioned BPA on this last point, it became clear BPA was concerned about irrigation ditch screens, but mostly the issue of adequate instream flows on the river. Simultaneous with the struggle to begin the Umatilla Fish Restoration Program, the Tribes were also laying the groundwork for the Umatilla Basin Project, which would bring water back to the river. But even so, BPA wrote to the chairman of Northwest Power Planning Council that the Umatilla comprehensive plan must be amended into the Fish and Wildlife Program to insure "full consideration of the cost effectiveness and prudence of additional implementation activities in the basin....BPA's support assumes that the production benefits attributed to the various enhancement projects... are accurate and achievable. ${ }^{47}$

In May, The Council gave its terse response: except for the unresolved water issues regarding the Umatilla Basin Project with the Bureau of Reclamation and the irrigation districts, no amendment was necessary. The ODFW comprehensive plan was merely part of a process that the Council had already accepted in $1982 .{ }^{48} \mathrm{BPA}$ chose to see this response as a de facto amendment to the Fish and Wildlife Program, 
a move it claimed cut the public out of the decision-making process. The Council's flat denial of BPA's position prompted anger in the Fish and Wildlife Division. Apparently, the NPPC's rebuff wounded some members within the Division. Adding a perceived insult to this injury, the Council's decision was written not by a full Councilman, but by a mere staff member. BPA replied angrily, claiming that unwillingness of the Council to send the program back to the amendment process showed a "lack of support" for the Umatilla measures.

A month after this exchange, the BPA project manager for the Umatilla Program, Thomas Vogel, told Council staff "Bonneville sees the Umatilla 'as an opportunity, not a commitment,"' and hinted strongly a connection between this statement and the Council's rejection of BPA's amendment request. ${ }^{49}$ Two things are remarkable about this exchange. First is Bonneville's injured response to the Council. The second is the thinly veiled threat against the Umatilla Fish Restoration Program. By claiming that the Umatilla Program was "an opportunity, not a commitment," BPA was essentially saying that it was the Bonneville Power Administration, and not the Northwest Power Planning Council, that had the final say as to which anadromous fish projects would get funding. This position flies in the face of the statutory language of the Northwest Power Act. But unaccountably, the Council never challenged BPA on this point.

Sometime that spring, Vogel released an undated paper that called on the parties to institute a "measured approach" to the Umatilla situation. Because of "a shortcoming of planning efforts," the paper said, there was no way to deal with "a 
substantial list of unknowns." To compensate for these "unknowns," the parties should proceed "only with those projects that will reasonably assure cost effective benefits." This language made clear that BPA would only advance those parts of the program that met its own criteria, criteria that Vogel gave away with his use of the word "benefit" in the same sentence as "cost effective." In effect, he claimed ultimate control over which measures of the program met his version of the costbenefit analysis. $^{50}$

Vogel's statement that there was a paucity of planning efforts ignored the vast mountain of studies on the river that made the Umatilla what Ed Chaney called the most studied river in the Columbia Basin. ${ }^{51}$ His implication that BPA was not legally obligated to fund the Umatilla measures of the Fish and Wildlife Program seems equally astounding - the Northwest Power Act clearly states that Bonneville shall fund projects approved by the NPPC. After the publication of "A Measured Approach," the Council, the Tribes, and ODFW had had enough. They took their case over the head of Bonneville's Division of Fish and Wildlife to the BPA administrator, James Jura. In a meeting on August 25, 1986, the plan's advocates made their case to Jura. The Umatilla, they maintained, had been studied more than any river basin in the Pacific Northwest. They had completed all the production plans anyone could desire, and outside of the issues involving stream flows, which they had temporarily solved with a trap-and-haul plan, they were ready to commence activity. Administrator Jura agreed to take up the issue. 
The Fish and Wildlife Division's resistance to the Umatilla measures shifted focus from the facilities themselves to the rehabilitation of the river. The habit of the Division to exaggerate, overstate, and misstate the cost of the hatchery's operations came to the attention of a member of the Council, Kai N. Lee, who found it as disturbing as the Tribes. In a letter to a colleague, Lee wrote:

On my way home from the last Fish 4 meeting, I ran into an acquaintance, whom I shall not identify right now, who passed along the following document....The paper was described to me as a BPA staff paper prepared for Administrator Jura's visit to the Umatilla Basin 31 October. The discussion at page 4 is particularly disturbing. The 6 -fold increase in the cost of habitat improvement and passage restoration activities sounds worrisome. BPA may be either inaccurate or quoting out of context. ${ }^{52}$

BPA's "context" was the cost-benefit analysis. And while most of the paper, entitled "BPA Concerns with Projects Ongoing or Under Consideration in the Umatilla Basin," had to do with the upcoming struggle over keeping water in the river, BPA still continued to hammer at the "increased costs" of the same fish passage improvements that it had cited in $1985 .^{53}$

Ed Chaney was quite used to the "contextual inaccuracies" of BPA. He had been dealing with it from the start of the program, and in 1986 he became so frustrated with BPA's endless delays that wrote an article for the Idaho Law Review. ${ }^{54}$ In that article he castigated BPA's Fish and Wildlife Division for exercising discretionary authority over the funding of the Umatilla projectdiscretionary authority BPA did not have ${ }^{55}$ Chaney acidly itemized the Division's misinformation and mistakes in a page for page and item by item detailing of how 
Bonneville had used the "power of the purse to establish its own shadow fish and wildlife program." ${ }^{56} \mathrm{He}$ characterized BPA's "dissembling" of information as "mean-spiritedness," and as a willful attempt to take control of the Umatilla Fish Restoration Program. ${ }^{57}$ In the essay, Chaney exhaustively chronicled BPA's resistance, stating that the Fish and Wildlife Division's goal was to co-opt the Council's role and to set up "a shadow fish and wildlife program" that would essentially establish BPA as the "final arbiter" of projects approved by the NPPC. ${ }^{58}$

After BPA's administrator visited the Umatilla in October of 1986, he agreed with the Tribes and committed BPA funds long held from the program. Jura committed more than just funds. He also committed energy. He replaced BPA Project Manager Thomas Vogel, who, according to Ed Chaney, "for years had stonewalled, dissembled, impugned, threatened, and otherwise attempted to frustrate state-tribal chinook restoration," with Tom Clune. Clune immediately contacted the Tribes and ODFW to develop "an implementation schedule based upon state-tribal priorities." Clune was "responsive to [the Tribes'] need for quick action on critical measures" with the Program. ${ }^{59}$ All parties involved came to an agreement on November $6 .^{60}$

The direct evidence shows that BPA resisted strenuously funding the Umatilla Fish Restoration Program. Why they resisted is less clear, but circumstances point to two possible reasons. The first is that Bonneville simply did not want to spend the money. In Bonneville's defense, it saw a desiccated river where salmon had not been able to survive for more than 70 years. The Tribes 
wanted to spend millions of ratepayer dollars in a river where there was little water, where the conditions that had originally killed off salmon still existed. The lower thirty-two miles of the Umatilla was totally inhospitable to fish in the driest season, exactly when salmon would be migrating. In 1986, when BPA published "A Measured Approach," there was no tangible evidence that there would ever be enough water. It made no sense to spend millions of dollars to make salmon extinct again.

A second possibility is that Bonneville wanted control over the entire Columbia River Basin Fish and Wildlife Program. Bonneville had been in joint control with the Army Corps of Engineers of the operation of the hydropower system for many, many years, and the Northwest Power Act threatened that control by making a biological entity equal with the industrial hydroelectric system. Since BPA would end up paying for any projects the Council recommended, it wanted the last word on any river management decisions-including those dealing with fish. If the Power Act meant that biologists would have a say in how the Columbia was run, then BPA would maintain control of the hydropower system by making sure that most of those biologists worked for Bonneville's Fish and Wildlife Division. Clearly, though, some element within BPA wanted to stall or kill the Umatilla program.

The language that BPA used in its Fish and Wildlife Division's memos and correspondence with the Tribes, the Council, and ODFW use the new lexicon of the Columbia. But on a close reading, it is clear that there is other language imbedded in the communication that conveys a much different idea. BPA revealed in its choice of 
words its lack of confidence in the Umatilla program. To stall or kill it, it would go so far as to try and take control of it. What remains unclear is whether BPA actually conducted a cost-benefit analysis that showed the Umatilla program would not pay for itself, and decided then to take over the program and kill it, or that it simply decided it was not going to fund the project and tried to justify itself by saying that the project was not cost effective. The Tribes' theory of putting salmon in the stilldry river failed to convince BPA of the project's worthiness - that much is certain.

Whether the managers in BPA's Fish and Wildlife Division understood that cost-benefit analysis was an obsolete tool in fish mitigation and mindfully dressed it in the words cost effective, or simply did not understand that the terms are fundamentally different, is really immaterial. Both possibilities show an ossified approach to fish management. BPA had great difficulty adapting to both the Council's new definition of mitigation (to include projects "off-site") and a lack of control over where its funds went. The fact is, if these new mitigation projects like the Umatilla Program seemed expensive, then that suggests strongly that the original cost-benefit analysis of the dams that excluded the biological value of salmon as part of its calculation, was flawed.

The Fish and Wildlife Division's effort to claim discretionary authority over Council-allocated funds was essentially an attempted palace coup d'état. There is absolutely no statutory authority for that agency to co-opt the Council's power as specified in the Northwest Power Act. Bonneville's Fish and Wildlife Division was unsatisfied with its role and sought to attempt to circumnavigate the Council, and 
retain control over what it considered to be its money. Ultimately, the coup failed. But the consequence of the Council's silence and not making a legal challenge to BPA's position, is that BPA maintains its Fish and Wildlife Division as an advisory agent in salmon management, an agency with motives that are not based on biology.

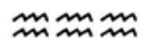

INSTITUTIONS, LIKE PEOPLE, SPEAK CERTAIN LANGUAGES. They have distinct personalities. After years of speaking a given tongue, performing a given task, an institution becomes accustomed to that task and its language and changes little unless forced. Change in a bureaucratic institution is painfully slow, since the people within it, accustomed to performing a particular job, have little or no incentive to change. Such was the situation BPA found itself in after 1980. Having run the Federal Columbia River Power System for forty years under the directive of rationality and the maximum efficiency of every drop of water, it was now in the situation of, as the fictitious Army Corps of Engineers colonel allegedly put it, "playing nursemaid to fish." ${ }^{\text {61 }}$ The Northwest Power Act was took the decisionmaking process out of BPA's hands, and mandated that BPA simply write checks. But the record shows that BPA did not intend to simply write the checks. It tried to control the process outright by appropriating control over funds. Only when ODFW and the Tribes went over BPA's Fish and Wildlife Division's head to the Administrator was the funding forthcoming. The goal of Bonneville's fish division appeared to be to bring the Columbia River Basin Fish and Wildlife Program under 
its control by using the "power of the purse" to choose what projects got funding and what did not. On its face, the establishment of a fish and wildlife division seems a step in the direction of ecological responsibility, until one realizes that Bonneville has no need for a fish and wildlife division at all. BPA's charge is to fund fish mitigation projects approved by the Council. What could a new division add to the body of knowledge provided by state, federal, and tribal biologists?

It is possible that the Division was divided on the issue between a "proUmatilla" faction and an "anti-Umatilla" faction. One thing is sure: to the extent that there were anti-Umatilla sentiments in the Division, John Palensky, head of the Fish and Wildlife Division, and Tom Vogel, BPA's Umatilla Project Manager, were major factors. It was Palensky's name attached to most of above documentation where cost-benefit analysis is confused with cost effectiveness. And the record is clear that it was Vogel who contributed to most of the delaying tactics that the Division engaged in.

But even after the costly delays, the Tribes, with the help of ODFW, built the Umatilla facilities, they did work, and they bred salmon and steelhead for release. The project was not perfect: the fish were being trapped and hauled the last thirty miles past the dried-out river, but the Umatilla Basin Act had not yet been passed by Congress. New water for fish was in the works. But nothing is simple. Although irrigators had drained the Umatilla, no one was requiring that they scale down their appropriations. A new conflict over old systems was brewing. 


\section{CHAPTER IV-RE-Watering The Umatilla: The Umatilla Basin Project}

If there's any salmon in that river, they'd need dirt bikes to get upstream.

-Tom Simmons ${ }^{1}$

"RAIN FOLLOWS THE PLOW" IS AS OLD A PLATITUDE AS ANY in the American West. ${ }^{2}$ In the struggle over the Umatilla fishery program, the Confederated Tribes could have coined their own variation of this expression: "water follows the fish." In 1982, the Tribes threw thousands of chinook smolts into the Umatilla, deliberately pressuring the status quo of salmon management. This kind of renegade fish management had the desired effect: the Tribes got their program off the ground. But reintegrating salmon into the Umatilla meant reintroducing water to the river as well. All parties recognized that without improved instream flows on the river, the whole point of the hatchery would be moot: salmon could not get up a Umatilla River that did not flow into the Columbia. Irrigation in the dry months claimed virtually every drop from the river.

At the same time that the fisheries restoration program was struggling through BPA's obstructions, another drama was unfolding over a more basic resource. Since a generous supply of cold water was absolutely necessary for reintegrating fish, the players that had controlled the flow of the Umatilla River for 
many, many years were about to be challenged. This challenge would have repercussions throughout the Umatilla Basin, and the entire Columbia River Basin.

The drama of getting water to the Umatilla revolved around a complex set of players. The instigators of the movement were the Confederated Tribes of the Umatilla Indian Reservation. With environmental resource consultant Ed Chaney taking the lead, as he had in the fisheries restoration program, the Tribes began an active search for water and allies to get it. The Tribes competed with the four irrigation districts of the area: the Stanfield Irrigation District, the Westland Irrigation District, the West Extension Irrigation District, and the Hermiston Irrigation District. These districts had been diverting water for over 70 years. The Tribes needed a strategy for dealing with this entrenched power.

These four districts worked to develop an extensive series of canals, ditches, reservoirs, and diversion dams in the lower Umatilla Basin. Stanfield Irrigation District diverted water from above the town of Echo, more than twenty miles up the river from its mouth. The Hermiston Irrigation District relied on diversion dams on the mainstem Umatilla and on water from a reservoir on Cold Springs Creek, a tributary of the Umatilla, to irrigate a vast area east of the river. The Westland Irrigation District irrigated another large area on the west bank of the river where the Umatilla turned north on its final reach. The West Extension Irrigation District withdrew water from behind Threemile Dam and pumped it to a canal that ran parallel to the Columbia River down to fields around Irrigon and all the way to Boardman, far outside the Umatilla Basin. ${ }^{3}$ 
The plan that all willing parties came up with would have to be built by the U.S. Bureau of Reclamation. In the 1920s, the Bureau built the original Umatilla Basin Project in accordance with the Newlands Act. Sixty years later, the Tribes petitioned the federal government to allow the Bureau to construct another Umatilla Basin Project. This time, it would be a water project to help salmon rather than irrigators.

As with the Umatilla Fish Restoration Program, the Bonneville Power Administration was involved in the water issue, for the Northwest Power Planning Council required BPA to put some money into the Tribes' re-watering design. Bonneville, however, did not want to fund water projects, and resisted any responsibility for any money not directly related to fish and wildlife improvements. Fostering this resistance was one of BPA's biggest customers, the Pacific Northwest Utilities Conference Committee, an umbrella organization for the Direct Service Industries (DSIs). DSIs purchased power wholesale from BPA. PNUCC clearly saw that any BPA funds spent on anything outside of repaying BPA debts to the federal government as a potential cost to "ratepayers," namely themselves.

The role of environmentalist in this drama is fulfilled by a group based on the west side of the Cascades in Hillsboro that is dedicated to protecting the waterways of the state. WaterWatch of Oregon opposed the Umatilla Basin Project as nothing more than another scheme for irrigators to plunder the scarce resources of the West. WaterWatch threatened litigation, which endangered the Project because Congress often refused to fund projects facing legal challenges. 
The first step belonged to the Confederated Tribes. To recover the river's water, the Tribes had two options. First, they could reassert their original water rights and take the irrigation districts to court. Because of the U.S. Supreme Court's Winters, the Tribes probably had enough legal precedent to claim their implied water rights to the Umatilla and thereby force the irrigation districts to leave enough water in the river to support a fishery. ${ }^{4}$ The second possibility was that the Tribes could appeal to the federal government through the Bureau of Reclamation to approve a new water project in the basin. After all, many reasoned, the Bureau's water projects during the 1920s had caused the problem, so they ought to solve it. Regardless of how they approached the problem, the Tribes needed allies, for whenever water is reallocated in the arid West opponents rise up like the wind on the Columbia Plateau.

$$
\text { t }
$$

\section{The Winters Doctrine}

The Confederated Tribes considered a direct legal challenge to water distribution on the Umatilla River by reclaiming their reserved, implied water rights. ${ }^{5}$ The concept of implied water rights comes from a 1907 Supreme Court decision (virtually the same Court that decided the Winans case) in Winters v. United States. The Court ruled that in signing treaties with the federal government Indian Tribes had reserved more than land and other explicit rights (like fishing). The Court held that Native peoples had not given up water rights in the treaties, and not even the admission into the union of a state within whose borders the reservation existed 
could defer or destroy those rights. ${ }^{6}$ The ability of an Indian tribe to evoke those implied water rights became known as the "Winters Doctrine." Unlike the doctrine of prior appropriation, tribal water rights were never revoked for nonuse.

Theoretically, all the Umatilla Tribes had to do was to assert their neglected water rights under Winters, and then watch the fish swim home.

But this is a simplified version of western water law. Indian water rights have undergone changes in lower court decisions, and through a federal law that modified Winters in by changing the adjudication of Indian water rights. The power of Indian tribes to appropriate water is not what it was or could have been.

Two issues in Indian water rights are most important. First, water rights are creatures of the states. In the humid East, the riparian doctrine was relied upon by river dwellers for many years. But in the arid West, the law of prior appropriations ruled the day. This doctrine is exemplified in the phrase "first in time, first in right," which means that rights are conferred in chronological order for those claiming water from a river. A farmer settling late in an area and claiming a water right might get a water right yet no water, if those ahead of him "in time" used it all. Because many treaties recognized the Indians as residents of the land "from time immemorial" and many of those reservations were established on part of the traditional lands, the Indian water rights were "prior" to any Euro-American irrigator. Further, "implied" rights meant that those rights reserved by the Tribes, which included rights on the lands ceded by treaty. This put the states at odds with Indian tribes and the federal government, because the a state could not regulate water 
within its own boundaries that the federal government claimed, and all Indian water rights were considered federal water rights. States were unable to challenge the United States government because of the doctrine of sovereign immunity. Sovereign immunity decrees that the federal government cannot be sued in state court against its will. When a state did manage to bring suit against the federal government over Indian water rights the suit was always heard in federal court, which nearly always ruled in favor of the Indians.

The Tribes' need to get water cases into federal and not state courts is illustrated in a 1917 Oregon Supreme Court case, Byers v. Wa-Wa-Ne. This is the pivotal case in the minds of tribal lawyers when they consider a Winters-style challenge to existing water allocations. The Byers case demonstrated the insecurity the Tribes feel toward their water rights. Although the case is an extremely narrow and highly flawed interpretation, the Umatilla Indians consider this case the "Achilles' heel" of Winters. ${ }^{8}$

The Byers case arose from a challenge by a tribal member to the water rights of a Euro-American woman who diverted a flow of Umatilla water to run her flourmill in Pendleton. Oregon Supreme Court Judge McCamant wrote that, because the Severalty Act of 1887 (also known as the Dawes Act) opened "surplus" reservation lands to settlement, Mrs. Byers held a legitimate water right. The U.S. Attorney presenting the case for the Tribes argued that the Tribes had an older, implied right under the Winters Doctrine. Judge McCamant rejected that argument, and ruled that the Winters Doctrine did not apply in this case. In the case of Winters, 
wrote Judge McCamant, the Indians had actually been irrigating the land and the Supreme Court stated that the Fort Belknap Reservation lands in Montana were useless without irrigation water. The situation on the Umatilla River and the 1855 Treaty between the Umatilla, Walla Walla, and Cayuse and the United States was different. Seizing on this point, the Oregon Supreme Court argued that "The [Fort Belknap] treaty evidenced an intention that the Indians should farm the lands on the reservation and they could not be farmed without irrigation." 9

These authorities do not hold, as we read them, that the mere creation of an Indian reservation by treaty impliedly secures to the Indians all water in streams which touch the reservation which they may at any time desire to put to a useful purpose. The Indians were given arid lands which could not be farmed without irrigation; it was the purpose of the government to induce them to farm, a purpose manifest on the face of the treaties. ${ }^{10}$

It was only under those conditions, according to Judge McCamant, that the U.S. Supreme Court "found in the treaties an implied grant of the water rights in question." 11

In other words, the Fort Belknap was fundamentally different from the Umatilla Reservation because the shape of the river valley made irrigation on the reservation uplands too expensive, therefore the Tribes were not entitled to water rights. Also, "witnesses" testified in the case that most of the Umatilla bottomland was "generally speaking...rocky and gravelly," and therefore ill-suited for irrigated farming. Irrigated agriculture was never intended for the reservation land on the Umatilla above Pendleton. Since the Treaty of 1855 "was silent" on the subject of water, the court ruled that no such right existed. 
This narrow interpretation of the Winters Doctrine in 1917 by the Oregon State Supreme Court seems rickety beyond belief today, considering the fact that agriculture has spread all over the lower reservation lands.

The Tribes could have challenged the Byers decision. They chose not to. The key to an excellent chance at winning such a challenge would have a lot to do with the venue in which the suit was heard. A federal court would probably be more sympathetic than a state court, but Congress passed a law in 1952 that relinquished federal supremacy over federal water rights, including Indian water rights.

That law was the McCarran Amendment. ${ }^{12}$ With this law, the federal government waived its privilege of sovereign immunity in regard to water rights issues. In other words, a state could now compel the federal government to appear in a state court to adjudicate water rights. In 1983, the Supreme Court strengthened the scope of this law when it ruled in Arizona v. San Juan Apache Tribe that the McCarran Amendment gave the states the power to adjudicate tribal water rights even if that state's constitution ruled that it did not have that power. ${ }^{13}$ This removed Indian water rights from a venue where Native Americans had enjoyed support of their rights - the federal courts - to a venue traditionally hostile to their interests-the state courts. Judges in Oregon state courts were unlikely to rule in favor of the Tribes if the Tribes invoked the Winters Doctrine and thereby laid claim to the entire watershed of the Umatilla Basin. A state court might be much more unlikely to overturn a state supreme court decision like Byers. The State of Oregon might cooperate with the Umatilla Tribes by sharing biological expertise in a project 
to revive fish runs, as ODFW did with the Umatilla Fish Restoration Program, but this was very different than allowing the Umatillas to invoke the Winters Doctrine.

A Winters Doctrine unrevised by the McCarran Amendment has awesome implications. In the Umatilla Basin, invoking the Winters Doctrine would mean transferring water rights from farms long accustomed to withdrawing water for their crops to the Confederated Tribes. It would then be the choice of the Tribes whether to grant appropriations of water to farmers and irrigation districts. If the Tribes chose to keep water in the river for the fish, that could cripple the local agricultural economy, an economy worth between eight and 50 million dollars annually. ${ }^{14}$ The Umatilla Indians also had fishing rights on other rivers in the ceded area where irrigation had hurt salmon runs: the Walla Walla, the Imnaha, and the Grande Ronde. Because the Winters Doctrine applied in theory to ceded lands (because Indians gave up rights and title to land but not rights to water), the Tribes could use the Winters Doctrine in all of the river basins in their traditional lands. They theoretically could become the water masters of northeastern Oregon and reclaim that water in the name of salmon.

Other tribes had seen their traditional game dwindle because of irrigation projects in the West. The Northern Paiute, for example, who had watched irrigation projects western Nevada obliterate the Lahontan cutthroat trout, fish that weighed up to fifty-pounds, and had migrated between Lake Tahoe and land-locked Pyramid Lake for generations. ${ }^{15}$ The Klamath Indians of Southern Oregon have fought to protect the sacred short-nosed sucker from irrigation diversions in the Klamath River 
Basin. ${ }^{16}$ Irrigation on literally thousands of square miles all over the West has inflicted losses on the habitat of wildlife used by native people. If other tribes could successfully invoke the Winters Doctrine it could begin a revolution of mammoth proportions in the way resources are allocated in the American West.

The McCarran Amendment was a radical revision of the Winters Doctrine. Allowing the states, entities traditionally hostile to tribal peoples, to adjudicate tribal water rights, swung the pendulum far from the federal and tribal position. Since 1952 , the tribes have lost many water law cases that before the 1950s were upheld all the way to the highest court. The legal ground of Indian water rights was far too unstable for the Confederated Tribes to risk a definitive decision that could backfire and curtail or abrogate of their treaty rights. For the Confederated Tribes to bring the state to court over water rights implied in Winters $v$. United States meant risking those rights in state court and losing. If the U.S. Supreme Court upheld such a decision, they could be lost forever.

A more recent development shows that states are also uncomfortable with the ramifications of the Winters Doctrine, despite their power to adjudicate tribal water rights. In 1998, the State of Oregon found the shifting ground of tribal water law a serious enough threat to the control of its natural resources that it entered into a compact with the Confederated Tribes of the Warm Springs Indian Reservation. The state and irrigators of the Deschutes River nominally recognized the sovereignty of the Warm Springs over allocation of water flowing east out of the Cascades into the middle Deschutes River under the condition that the Warm Springs guarantee local 
irrigators specified amount of water. This agreement was the culmination of years of negotiation between the state and the Warm Springs Tribes. It recognized the potential havoc on Oregon water rights the Tribes could wreak if they invoked Winters Doctrine. The agreement assures the local irrigators water, but puts the Tribes in charge of that water. ${ }^{17}$

However, that agreement took place sixteen years after the Umatilla Basin Project was proposed in 1982 . The legal flux of tribal water rights was such that the Confederated Tribes felt it unwise to challenge irrigation interests head-on. With no guarantee that they would win they could easily lose more than just a case, but also have their water rights defined in such a way as to render those rights impotent. Also, litigation takes time. Don Sampson of the Umatilla Tribes has pointed out that the Yakama Indians have filed a suit based on Winters against the Sunnyside Irrigation District for the Tribe's water rights in order to provide better instream flows for their salmon supplementation plan. That suit is still in litigation. To this day the Yakima River has "not a single drop more water than when [the Yakama] started" the suit. ${ }^{18}$ Bringing suit in the state court seemed too risky to initiate.

Second, the Confederated Tribes had no wish to see the farming economy of Umatilla County destroyed. They recognized that today's irrigators in the Umatilla Basin "did not create the problem, they inherited it." 19 The Confederated Tribes did no intend to alter the face of water allocation policies in the American West. If they lost, an important weapon would be gone. In many cases, the threat of a thing is 
more potent than carrying out the threat. It made more sense to keep a potential Winters Doctrine suit in reserve as a just such a threat.

Therefore, the Tribes chose another option. They elected to go outside the region and solicit the federal government for a project that would solve the Umatilla Basin's water problems. This method is consistent with the history of development in the American West, development that depended on the capital and expertise of the U.S. Government. ${ }^{20}$ In this case the Tribes needed to convince the U.S. Bureau of Reciamation to undertake studies and develop a project that the U.S. Congress would approve and fund. By 1982, CTUIR had voiced its opinion to the Bureau:

A BurRec instream flow enhancement project is essential to restore the salmon and steelhead productivity of the Umatilla River Basin and to protect Indian rights to fish reserved by treaty with the U.S. Government in exchange for cedeing [sic] vast areas of land including the entire 2300 square mile Umatilla River drainage. ${ }^{21}$

To convince Washington, D.C. to spend the money would require allies. The Tribes went into negotiations with the irrigation districts with the carrot of status quo water allocations for all who had water rights. They explicitly cited the Treaties of 1855 as their primary weapon, but all involved seemed to understand that the fishing rights were connected implicitly to the big stick of the Winters Doctrine.

$$
\text { H) }
$$

\begin{abstract}
Allies
In 1982 the Bureau of Reclamation began an in-stream flow study of the Umatilla at the request of the Council and the Tribes. This study outlined "alternative
\end{abstract}


means of increasing Umatilla River streamflows for salmon and steelhead production...without adversely impacting present irrigation uses." But a study did not mean a project. The Tribes needed support from other interests in the Umatilla Basin, and so they approached irrigation districts and businesses. Many business leaders in the Pendleton area were also managers of irrigation districts. The region's economy was tied to irrigated farming and it made sense to get the other economic interests into the lobbying effort. ${ }^{22}$

To this end, Ed Chaney met with the heads of the major irrigation districts at the Stanfield fire station on October 26, 1982, to spell out the Tribes' need for water. These initial negotiations hinged on a single tribal goal: the Tribes would bring back their salmon at almost any cost. Chaney's presentation cited the "Tribes' treaty right to fish." The Tribes, he told the irrigators, wanted to accomplish salmon restoration with as little disturbance to the economic order as possible. But, if necessary, they would exert all the legal and political muscle they had. Their right to salmon in the Umatilla Basin was not up for discussion. Chaney pointed out that the Tribes had made numerous concessions over the years, even in planning the Umatilla Fish Restoration Program in particular. For example, Chaney told Hadley Akins, the manager at the U.S. National Bank in Pendleton, that the Tribes had gone so far as to select a stock of fall chinook that spawned later than most and thereby interfere the least with the irrigators' busiest water season. ${ }^{23}$ The irrigators nominally agreed with Chaney and the Tribes' position. The irrigators understood too well that the Tribes, armed with both the Boldt decision and the Winters Doctrine, had the higher legal 
ground, and that if push came to shove (and litigation) the irrigators stood to lose all. They realized that the Tribes had the potential to destroy their industry, and accordingly agreed to help back the Umatilla Basin Project. ${ }^{24}$ Both sides risked all in litigation, and so both sides chose to ally instead.

This preliminary agreement between the Tribes and irrigators did not transform the area's water problems. In the Summer of 1983, there was a small incident that exemplified the continuing problems of water appropriation in the basin and also foreshadowed future conflict. The Oregon Water Resources Department (OWRD) responded to three new claims on the Umatilla by issuing water permits to Don Brown, Chester Prior, and Ivon J. Cook to draw water from the Umatilla. The Tribes protested. The Umatilla was already overdrawn. Just as the Tribes were forging a working relationship with irrigators of the area, the State was continuing to over-appropriate the river. This incident shows how State agencies worked at crosspurposes on the Umatilla. ODFW was working with the Tribes to plan and construct the Umatilla Fish Restoration Program to bring back salmon to the river, while at the same time, OWRD was giving away river water that the fish used. To the Tribes, this "promised the river twice," no different than what the federal government had done back in the heyday of irrigation projects in the basin in the 1920s. Then, the government promised the Umatilla's waters first to the Umatilla Tribes through treaty by guaranteeing fishing rights at "all usual and accustomed places," then promised it to irrigators through the construction of the original Umatilla Basin Project in the 1910s and 1920s. The treaty did not guarantee water per se, but it 
implied that, since the Umatilla River was a usual and accustomed place and there needed to be a river for the salmon to survive. In 1983, the Tribes' complaint against further appropriations was more of an irritant than a stumbling block to progress, but this issue was not dead; it would come back with a vengeance seven years later when environmentalists criticized over-appropriation. ${ }^{25}$

In 1983, the Bureau of Reclamation completed its instream flow study, paid for by BPA. BPA paid for the study, as it did many other studies throughout the Columbia Basin, because it would demonstrate the water resources available to salmon, in this case salmon produced from the Umatilla Program. In July, the Bureau told representatives of the Tribes and the irrigators that it was seeking a waiver of the required cost-benefit analysis on the project from the Department of the Interior. This was a refreshing change for the Tribes: a major federal bureaucracy understood that the biological goal of a particular project could not be measured monetarily. The Bureau correctly understood that the benefits of the project could not be tabulated, and had no wish to try. ${ }^{26}$

The Bureau outlined two possibilities for a water project. First, the Bureau could provide the irrigators with Columbia River water. To do this the Bureau would construct a series of canals and huge pumps to draw water from behind McNary Dam into the interior of the Umatilla Basin. Irrigators would then leave the cleaner, colder Umatilla for salmon habitat. In other words, the project would exchange Columbia River water with irrigators for Umatilla River water. It was important to actually exchange water, not just refill the Umatilla with Columbia water, since 
salmon would have a difficult time both imprinting on the Umatilla as juveniles and navigating home as adults if they were smelling water from the wrong river. The second possibility was that the Bureau could build a reservoir upstream, and the Tribes could use this lake to keep water in the Umatilla at times crucial to salmon. The favored site was Bear Creek, a side canyon of the North Fork of Meacham Creek. Meacham Creek is a tributary that flows south-to-north out of the Blue Mountains into the Umatilla on the reservation. Its steep walls are ideal for a dam to insure adequate instream flows for salmon and steelhead. This seemed a reasonable solution because there were already a number of man-made lakes in the basin whose water was contracted by the irrigation districts.

In 1984, based on their determination to provide water for their salmon restoration project, the Tribes succeeded in gathering the four big Umatilla irrigators and local businesses into a partnership. The goal of this alliance was to convince Congress to appropriate money for a substantial water project. The principal appropriators of the Umatilla River were the Standfield Irrigation District, the Westland Irrigation District, the West Extension Irrigation District, and the Hermiston Irrigation District. This coalition called itself the Umatilla Basin Project Steering Committee. It selected local businessman Hadley Akins as its chairman. Even though they understood the Tribes' legal capability and resolve, a summary of the July 11 meeting shows that the four irrigation districts were still wary of change, and underscores the fragility of this new alliance. In April 1984, as part of the irrigation districts input into the nascent Umatilla Basin Project, the 
districts had sent a list of their desires for this new project to the Bureau. Among their requests was one for new sources of irrigation water. When the Bureau of Reclamation responded that its project was not intended to provide more water to irrigators, many irrigation leaders stated that there would be little support for the Project from the districts. Bill Porfily, the manager of the Westland Irrigation District, made it clear that "the irrigation districts want to get something more from the project than a guarantee of the status quo. If they get no further benefit from the project then the districts might as well allow the tribal litigation to run its course." In the past, the Bureau's irrigation projects always meant more water for farming. This time, the Project was intended to bring more water into the basin, but just enough to meet irrigators' current withdrawals. Porfily opportunistically tried to secure even more water for the irrigation districts in exchange for supporting the Tribes' plan. If the Bureau could not promise something extra for the Umatilla irrigators, they would see just how far the Tribes would really go in the courts. By suggesting that the irrigation districts would "allow the tribal litigation to run its course," he was threatening to not support the Project. This attitude is an interesting example of how some irrigators in the Columbia Basin had come to see Bureau of Reclamation projects. They considered it a matter of course that they would get more water, not less, or even the same. ${ }^{27}$

Porfily's threat to refuse support for the Project, which could have hurt its chances with Congress, turned out to be a bluff. Because the Umatilla Basin Project proposed to operate with virtually the same appropriation framework as before, 
within the status quo of river operations, irrigators would not be required to change the way they farmed. They stood to lose nothing. Irrigators knew that any tribal litigation over water would throw the system into chaos, with dire results if the irrigators lost. Because nobody minds seeing large amounts of federal money come into their county, the irrigators joined a large cross-section of the basin's businesses and the Tribes and entered into the Umatilla Basin Project Steering Committee compact. These groups worked together to show unified support in the Umatilla Basin and lobby for the Project with Congress. ${ }^{28}$

In March of 1985 the Bureau issued a status report on the Umatilla Basin Project. For the first time, here was a completed rough draft of the "Recommended Plan" to exchange water with the four irrigation districts. This draft of the plan had two "phases." The first was a plan to build a pumping station behind McNary Dam that would draw water out of the Columbia and into a canal. This canal would then lead to the Cold Springs Reservoir, where the Stanfield and Hermiston Irrigation Districts could then draw water. Stanfield would exchange its rights to 20,000 acre feet of water from McKay Reservoir south of Pendleton for the same amount of Columbia water. It would then only withdraw about 17,000 acre-feet from the Umatilla at the Stanfield Diversion Dam. The Hermiston Irrigation District would draw 13,000 acre-feet from the Columbia-Cold Springs water, although it would still be withdrawing over 56,000 acre-feet from the Umatilla at Cold Springs Diversion Dam. The West Extension Irrigation District would rely on a modified Bureau of Reclamation pump at the mouth of the Umatilla to replace water it withdrew from 
behind Threemile Dam. Exchanging this appropriation as soon as possible for the soon-to-be-returning chinook was crucial. It was WEID's withdrawals from behind Threemile Dam had desiccated last three miles of the Umatilla, leaving it dry in the fall, when fall chinook were coming home. If WEID could draw Columbia River water and leave Umatilla water alone, then salmon would be able to get to the new fish ladders and traps at Threemile Dam. The Bureau estimated the cost of this first phase at $\$ 37$ million. $^{29}$

In the second phase, the Bureau of Reclamation planned to build a new reservoir on Bear Creek, a tributary of Meacham Creek, far upstream on the reservation. The Bureau intended water from this new reservoir to replace the Westland Irrigation District's 3,600 acre-feet appropriation from McKay. The Bureau estimated this phase at over $\$ 78$ million. The draft also included fish passage improvements and screens on irrigation ditches. Finally, the plan stipulated that BPA would pay the electrical costs of pumping the water. ${ }^{30}$

Seven months later, the Bureau of Reclamation presented a revised "Summary" of the Project. In this revision, the Bureau informed the Tribes that any new dam on the headwaters of the Meacham Creek was not feasible. At a combined $\$ 188$ million for both pumping plan and reservoir, the project was too expensive. Therefore, the revised summary recommended just the elaborate pumping plan which would cost an estimated $\$ 40$ million. (The final cost was over $\$ 46$ million.) In addition to cost, the Bureau hinted that there was little support in Congress for projects that included new dams. By the 1980s, the time of dam building was past. ${ }^{31}$ 
One crucial element to the plan—and the element to prove the most controversial—was the significant cost of electricity required by the huge pumps that would draw water out of the McNary pool. The Bureau's Project plan identified BPA as the most logical source of power, since it controlled the hydroelectric power of the Columbia system. For their part, the Tribes saw the Umatilla Basin Project as interdependent with the Umatilla Fish Restoration Program, and be consistent with the Northwest Power Act BPA was the most appropriate agency for the pumping power. If BPA supplied the electricity for the Columbia River pumps, then the pumping costs would not be figured into the overall costs of the project, thus leaving more money for sorely needed stream improvements on the river. ${ }^{32}$

In 1986, as soon as it became evident that there was enough support for the Project to involve Oregon lawmakers, the Steering Committee and the NPPC began to lobby Senator Mark Hatfield and Representative Les AuCoin. Both were members of their respective chamber's appropriations committees. Senator Hatfield had been sympathetic to the Umatillas for many years, and saw this as an opportunity to make good on a more than century-old promise: that there would be fish in the rivers for time immemorial. He agreed with Councilman Don Godard that the Umatilla Basin Project was more than the Council could handle and any water project on the scale being discussed would need federal funds. It seemed that this unlikely coalition of farmers and Indians were on the verge of completing their unprecedented agreement: to revive a river without traditional animosities getting in the way. ${ }^{33}$ 


\section{Power}

The traditional rivalry of Indian and irrigator might have reached a tenuous truce, but other river users had different vested interests. For the Bonneville Power Administration and its constituents, for example, water was not the issue, but power. Locally, the Umatilla Basin Project would be trumpeted as "right for the environment" and "morally essential." ${ }^{34}$ But regionally, aspects of the Project came under attack. As soon as it became clear that the Project included this powerproviding role for BPA, both Bonneville and the Pacific Northwest Utilities Conference Committee (PNUCC) began to resist the plan. In 1986, as the Umatilla Basin Project Steering Committee prepared to approach the powerful appropriations committees in both houses of Congress, BPA and PNUCC attacked the project. ${ }^{35}$

Because of the lack of available sources, there is a gap in the documentation at this point, but it is clear that Bonneville discouraged the idea of the Project. In May, Hadley Akins, the Steering Committee's chair, blasted BPA's Assistant Power Manager's "completely negative attitude" toward the project that ignored years of patient negotiating and compromise by the local participants. The Project's "adversaries," he wrote, were not local, nor national, but regional- the Bonneville Power Administration.

In June, BPA's Assistant Power Manager, Janet McLennan, wrote to the Bureau of Reclamation. McLennan unequivocally rejected any role for BPA in the pumping Project. The Project was not part of the Council's Fish and Wildlife 
Program, so providing power was fundamentally outside its responsibilities under the Northwest Power Act. If BPA supplied the electricity for the pumps, it would require an amendment to the Council's Fish and Wildlife Program, a lengthy proposition. Any other appropriation of Bonneville funds would have to come from Congress, which "might delineate BPA's role, if any," in any further fish and wildlife projects. Before BPA would consider getting involved in the Project, it would have to "compare the cost of providing fishery benefits... with the cost of funding other offsite mitigation projects in the region." In other words, BPA would not have anything to do with the Project unless that involvement relieved it of its responsibilities in the Umatilla Basin. McLennan formally requested that the Bureau not include BPA as a "cooperating agency" in the Project Planning Report. It added that BPA had an interest in the basin's fish enhancement program. ${ }^{36}$

This tactic is strikingly similar to that used by Bonneville against the Umatilla Fish Restoration Program. Whenever it got the chance, BPA slowed the progress of the Tribes' program by demanding that the fish and wildlife program be amended to include whatever "new" item BPA disagreed with. In the case of the Umatilla Basin Project, Bonneville had better legal justification, since it saw funding the power for the Project as a violation of the "in lieu" clause of the Northwest Power Act (described below). This justification allowed BPA to simply reject outright the role identified by the Bureau and the Tribes, rather than merely stall as with the fish restoration program. 
The Tribes were not going to wait until Congress voted on a water project for the Umatilla. They knew that the chinook that they had released back in 1982 would be coming back soon, and those fish needed water in the interim between the time that Congress debated and decided fund the Umatilla Basin Project. For this interim water, funds would have to come from the Council. The Bureau of Reclamation recommended retrofitting existing pumps, ditches, and canals to exchange some water with West Extension Irrigation District for re-watering the lower three miles of the Umatilla. Since this water was crucial to the fish that the restoration program had introduced, it made sense that it should be paid for by Bonneville. Therefore, the Tribes introduced an amendment to the Fish and Wildlife Program for power to pump interim water as they waited for a federal water project. ${ }^{37}$

In 1987, Senator Hatfield introduced Senate Bill 1613, initiating the Umatilla Basin Project. Now that there was a bill before Congress, the Pacific Northwest Utilities Conference Committee became Bonneville's champion to keep BPA from becoming involved. PNUCC is a consortium of Bonneville's biggest customers: the direct service industries, which includes aluminum factories, private utilities, and public utilities. It argued strenuously against Bonneville's supplying money for the interim water, especially to provide the power for the pumps. PNUCC saw that the cost of the electricity would be passed on to ratepayers through its constituents. These industries feared they would ultimately pay for the pumping through increases in their power bills. PNUCC maintained, just as BPA argued against the Umatilla 
Fish Restoration Program, that ratepayers should not be responsible for fish mitigation in areas unaffected by hydroelectric dams. ${ }^{38}$

PNUCC's position in regard to the Project might seem reasonable, until one considers its earlier reaction to the Umatilla Fish Restoration Program. In 1985, PNUCC hired a biological consultant, Don Chapman, to examine the Comprehensive Plan for Rehabilitation of Anadromous Fish Stocks in the Umatilla River Basin, written by ODFW. The Comprehensive Plan was the report that ODFW and the Tribes produced in response to BPA's request to see the "hypothetical" fish produced by each stream improvement. ${ }^{39}$ PNUCC cited Chapman's examination of this ODFW report and stated that the fishery goals of the Umatilla program "cannot possibly be achieved until sufficient water flows are provided, particularly in the lower sections of the Umatilla." ${ }^{40}$ One year later, PNUCC argued against the water allocation that would make restoration feasible. A 1986 letter from PNUCC to the Bureau of Reclamation stated its basic position. First, BPA had no obligation to pay for fish mitigation of any kind in the Umatilla because the damage was a result of irrigation, not hydropower. Second, BPA had no business funding the costs of the pumps. Third, that increased stream flows usually would end up benefiting irrigators, not fish. ${ }^{41}$ This last item shows an interesting_break between river users. To protect its own interests, PNUCC was willing to attack irrigators, who traditionally made up part of an alliance of river users-irrigators, direct service industries, and barge operators. 
In PNUCC's opinion, Bonneville's involvement violated the Northwest Power Act's "in-lieu" provision. The Act prohibited BPA from funding anything "in lieu of other expenditures authorized or acquired from other entities under other agreement or provisions of law. ${ }^{, 42}$ According to PNUCC, if the federal government was going to fund and construct the Umatilla Basin Project, then the pumping was the responsibility of the agent of the federal government, the Bureau of Reclamation. Bonneville had no role to play.

Further, as PNUCC pointed out in a 1988 letter to Senator Hatfield, for BPA to pay for such pumping constituted a subsidy of irrigators by ratepayers. In addition, PNUCC disagreed with the Council's interpretation of "mitigation." PNUCC found BPA's role in projects such as screening irrigation ditches from young salmon inappropriate since it was addressing issues that had nothing to do with hydropower generation. ${ }^{43}$ It argued that the Umatilla Basin Project's benefits to the fishery were "overstated." In March, PNUCC sent a flyer to its constituents, reporting that Congress was going to obligate Bonneville "to provide free pumping for fish." Impacts to Umatilla salmon were not caused by the federal hydropower system, and it urged its members to "contact Senator Hatfield... and express your opposition to the BPA provisions of this legislation." 44

What PNUCC really feared was a precedent-setting appropriation of Bonneville funds to pay for damage done to salmon streams by irrigation. There were many rivers on the plateau degraded by irrigated farming, like the Imnaha, the Wallowa, the Grande Ronde, the Walla Walla, the Tucannon, and others. These 
rivers flowed through treaty-ceded lands where the all Treaty Tribes had fishing rights. If BPA was forced to pay to put water back into one river like the Umatilla, there seemed no limit as to how many river basins it might be required by the Council to re-water. ${ }^{45}$ PNUCC considered funding the big irrigation pumps a "Pandora's box" of mitigation projects would come out of BPA's pocket, even though Bonneville had nothing to do with the fish disappearing from a particular river. $^{46}$

For their part, the Tribes were just as insistent that BPA pay for the pumping, both for the project itself, and the water that the river would need in the interim period before the project was completed. In 1986, the chinook smolts tribal biologists had released in 1982 were to return, and the Umatilla Basin Project would be under construction but not completed. Ed Chaney anticipated Bonneville's resistance in a September letter to CTUIR Chairman Ken Hall. Chaney wrote of the necessity of gaining "leverage in the upcoming battle to get BPA to provide the pumping power for the project via our proposed amendment to the Columbia Basin Fish and Wildlife Program. ${ }^{, 47}$ Because the Council had stated that mitigation could proceed far from the source of the damage, Chaney saw BPA's paying for pumping power totally consistent with mitigation. Regardless, PNUCC's insistence that Bonneville be excluded from the project proved in vain. The Bureau of Reclamation went ahead with their project plan and in 1988 Congress passed the Umatilla Basin Act, which endorsed and appropriated funds for the Bureau's Umatilla Basin Project as planned. The act explicitly confirmed that Bonneville would "provide for project 
power needed to effect the water exchange with irrigation districts for purposes of mitigating anadromous fishery resources." The act stated that this was "consistent with provisions of the Columbia River Basin Fish and Wildlife Program...." ${ }^{48}$ This legislation negated the question of "in-lieu" funding for power.

According to a 1989 draft, the Umatilla Basin Project called for three stages. Before the Bureau could implement Phase I, it had to address the so-called interim pumping problem. The salmon the Tribes released into the river back in 1982 were due back, followed closely by the first returning fish produced by the new Minthorn Springs facility. To provide water for the returning Umatilla fish, the Bureau would pump Columbia River water into the existing infrastructure of the irrigation districts. This water would water the last three miles of the Umatilla was to be done with. This part of the project would provide water enough water until the new Phase I was built.

Phase I, as previously described, would replace water that the WEID took from the Umatilla at Threemile Dam to the west. It was this appropriation that was the most immediately grievous to migrating fish, for it left the last three miles totally dry in the fall. If the Tribes could get returning salmon up to Threemile Dam, the new collection facility (part of the Restoration Program) would gather the chinook and either spawn them at the Threemile facility or transport them upstream by truck where they could be released and continue their migration to spawning grounds on the reservation. This could hardly be called a "naturally" spawning salmon, but the years of human-induced drought could not be overcome in a single stroke. 
Phase II, as the Bureau of Reclamation now called this part of the Project, would provide water to the Stanfield and Hermiston irrigation districts. Those two districts took most of their water from McKay Reservoir, ten miles south of Pendleton. But there were also several irrigation diversions on the reach of the Umatilla between Echo and Threemile Dam that naturally spawning fish would eventually need in order to get to spawning grounds on the reservation and beyond.

Judging by its communication with PNUCC, the Tribes, and the NPPC, the Bonneville Power Administration did not have any intention of providing the funds needed to bring salmon back to the Umatilla River. Unlike BPA's response to the fish restoration program, where it fought by itself to slow or kill funding, it was BPA's chief constituents, represented by PNUCC, which fought BPA's role in the Umatilla Basin Project. Bonneville did not object. This, at least, gives some perspective as to whom Bonneville felt responsible. Clearly, it was not the Northwest Power Planning Council.

\section{HEHE}

\section{"Pork Wrapped in an Indian Blanket"49}

In 1987, the Bureau of Reclamation proceeded installing pumps in the McNary Pool and building a delivery system to irrigators on the west side of the Umatilla. In the interim, existing infrastructure, that is, canals and ditches and pumps already used by various irrigation districts, would shunt some Columbia River water to WEID. 
The unlikely alliance between Indians and irrigators marked an important shift in the struggle to re-allocate western resources according to values other than extraction. Suddenly, environmental and cultural concerns became integral parts of the discussion. But although environmental restoration was the ultimate goal of this project, not all environmentalists appreciated another water project in the arid plateau. Just as conflicts over details of funding with BPA and PNUCC were beginning to subside, there came an attack on the project from another quarter. The Indians had united with irrigated farmers because those traditional extractors had control of the water and, barring a lengthy court struggle, would always have the last word. Now they watched as their partners the irrigators came under fire from an environmental group.

This environmental group, WaterWatch of Oregon, had been worried with flows and irrigation practices in the Umatilla Basin since the late 1980s. WaterWatch saw the Umatilla Basin Project as another pork barrel project for irrigators camouflaged in good will for Native Americans, a project that would take water out of the Columbia now that the Umatilla was dry. ${ }^{50}$ The more WaterWatch looked at the project and tried to make their concerns known to the state, the more frustrated they became. So, WaterWatch turned to the tool that the Tribes had rejected years earlier: litigation. By tangling a project still in the panning stages in the courts WaterWatch's threatened litigation could convince Congress that the project was too contentious to fund. This environmental group became a major actor by threatening the entire process so carefully built by the Tribes since 1980 . 
WaterWatch had spent years corresponding with the Oregon Water

Resources Department (OWRD) urging that agency to enforce Oregon water law on the irrigation districts of the Umatilla River Basin. Specifically, WaterWatch accused the OWRD of complicity with the "waterspreading" that the irrigation districts had been engaged in for years. Waterspreading is the sale of an irrigation district's unused irrigation water to other farmers, or even other irrigation districts. According to Oregon water law, when an irrigator initiated state mandated water conservation techniques and this implementation resulted in less water withdrawn, then the irrigator must leave that saved water in the river. But in practice, many irrigators from the big four irrigation districts - the Hermiston, Stanfield, Westland, and West Extension Irrigation Districts—would sell that "excess" water, "spreading" the water to other farmers outside their boundaries.

The Umatilla Basin Project had been stalled for two years because of "White House budget cutters," according to the Oregonian. ${ }^{51}$ The Reagan administration's budget for 1988 had no Umatilla money. In Spring of 1991 the House Appropriations Committee reinstated \$4 million dollars in funds to complete Phase I of the project. By 1991, WaterWatch decided that OWRD had not acted on WaterWatch's concerns. Informed of that the Bureau of Reclamation was proceeding with the Umatilla Project, WaterWatch attacked. In September 1991, it wrote to Senator Hatfield, informing the Umatilla Basin Project's chief sponsor in the senate that "illegal water marketing activities" endangered the capability of the Umatilla Basin Project to achieve its goals. ${ }^{52}$ WaterWatch also filed a petition to amend the 
Umatilla Basin Project. In order to "encourage restoration" of the Umatilla River, WaterWatch demanded that OWRD "terminate illegal, unpermitted, and forfeited diversions and uses." 53

WaterWatch backed up its charges by producing several OWRD and Bureau of Reclamation memoranda showing that OWRD had long known about illegal waterspreading. OWRD's internal memos show that it instructed the Westland Irrigation District to cease his practice in 1986 , but did nothing to enforce compliance. ${ }^{54}$

The Bureau of Reclamation did not escape the wrath of WaterWatch. In a letter to John Keys, the regional director of the Bureau, WaterWatch informed the Bureau that it must

enforce Bureau of Reclamation contracts for McKay Reservoir water....Westland Irrigation District is violating its contract with the Bureau of Reclamation by marketing McKay Reservoir water to Teel Irrigation District individuals. Other irrigation districts in the Umatilla Basin are also marketing water in violation of federal contracts. ${ }^{55}$

The so-called Teel Irrigation District was one of the smaller entities of two or three farmers that had limited access to the Umatilla and therefore bought unused water from one of the established four irrigation districts. Since McKay reservoir was a part of the original Bureau of Reclamation project, it still had nominal control over some of that water. If the Bureau failed to deal with illegal Westland Irrigation District withdrawals, or confront OWRD's lax enforcement, then it would "violate Congressional intent as expressed through the Umatilla Basin Project authorization legislation" which was to restore streamflows for anadromous fish. ${ }^{56}$ Based on this 
history of heedlessness, WaterWatch would oppose the project unless the Bureau and OWRD would enforce their own rules.

This attack came at a critical time. Congress demanded as part of the Umatilla Basin Project Act that the Bureau examine the existing operations of water allocations in the basin. ${ }^{57}$ The Bureau of Reclamation and OWRD had just applied for the necessary permits from the federal and state governments to alter the original Umatilla Basin Project (constructed between 1906 and 1927) and change OWRD's method of determining water rights and allocations. If WaterWatch sued the government over the Umatilla Basin Project, that could threaten the second important Phase. The opinion of the Bureau was that Congress would balk at continuing to fund a water project that was in litigation.

WaterWatch's accusations precipitated a new crisis when, in 1991, the Portland Oregonian printed a feature article entitled "The Umatilla River Blues." This story, which ran over 2,500 words, largely backed up WaterWatch's allegations. The article chronicled the history of over-appropriation from the turn of the century to the present time. It said that the U.S. government essentially "promised the river twice: to the irrigators between 1904 and 1924, and to American Indians" in the Treaty of 1855. "The Umatilla River Blues" also delved into some of OWRD's poor history of over-allocating the Umatilla River, showing OWRD's complicity in waterspreading. For example, in 1984, William Young, the Director of OWRD, awarded a water right to a farmer named Don Brown without the benefit of public comment - a transaction of which the Tribes had at the time complained bitterly. 
Young had dismissed those tribal complaints. Then, when the Bureau of Reclamation tried to examine WID's records to investigate the possibility that WID had been waterspreading to Brown before the Brown was granted the water right, the Bureau found that Westland had destroyed its records. ${ }^{58}$

Reaction to the article was vociferous and immediate. On October 291991 , John Keys wrote in a "Letter to the Editor" of the Oregonian that the "Umatilla River Blues" "disappointed" him. "It was frustrating," he wrote, "for those of us...who accepted the challenge to solve a problem to have the resulting product labeled a 'fraud' by Water Watch of Oregon." ${ }^{, 59}$ In November, Keys heard back from WaterWatch. Tom Simmons, the chairman of the organization, wrote to Keys to reiterate the demands of WaterWatch: that the Oregon Department of Justice assign a special prosecutor to "ensure enforcement of state water laws in the Umatilla Basin," and that the Bureau also release all documents that it had showing its own unwillingness to enforce water laws. While mentioning that WaterWatch preferred negotiating to litigating, Simmons nevertheless stated clearly that it would request a hearing by Congress on the waterspreading activity and how Congressional intent was being undermined by the Bureau and OWRD. "If the Phase II permit is thrown into a contested case hearing, it is not likely the issues will be resolved in time for Congress to budget Phase II costs next year."

That same October, WaterWatch's chief counsel, Bill Kloos, sent the Oregon Water Resources Commission a letter commenting on specific water permit applications under consideration by the Commission from. Kloos' comments were 
intended to convince OWRD to monitor actual withdrawals from the Umatilla so that irrigation districts would not simply continue to appropriate Umatilla River water while they were withdrawing Columbia River water from the Project. WaterWatch feared that the irrigation districts would sell this water outside districts. The letter itemized the way WID and the Hermiston Irrigation District continued to waste and illegally divert water. ${ }^{61}$

The institutional response was also swift. On November 25, 1991, OWRD issued a "Notice of Public Meeting on Enforcement Schedule for the Umatilla River and McKay Creek." ${ }^{62}$ The Notice outlined the measures the OWRD intended to take in order to meet the goals of the Umatilla Basin Project. From September 1991 to Spring of 1994, this schedule itemized many of the concerns WaterWatch had mentioned, such as examination of the mid-Umatilla rights claimed by the Teel Irrigation District, figuring out who actually used McKay Reservoir water, and looking closely at how ground water use affected Umatilla streamflows. Also, OWRD promised to institute a monitoring system to ensure water withdrawals did not exceed a district's approved rights.

Not surprisingly, reaction to OWRD's new proposals goaded by WaterWatch's threat, varied according to what camp one represented. Irrigation districts were outraged. At OWRD's December 3 public hearing, Bill Porfily, manager of the Westland Irrigation District, made the dire prediction OWRD's actions would "bankrupt people." Irrigators considered it ridiculous that an environmental group could hold a federal project "hostage." To them, this was a 
typical case of a west-side environmentalists, out of touch with the farming culture of the interior, sticking its nose into an east-side situation where all the parties involved agreed. ${ }^{63}$

For its part, WaterWatch saw a huge federal project going to benefit the same irrigators that had killed the river. The fact that this project was designed to help salmon and the Tribes was irrelevant. WaterWatch saw its role as halting the trend of abuse and over appropriation of Oregon's rivers. The Umatilla was a river where WaterWatch would take a bold stand.

For the Tribes, the potential fallout from WaterWatch's petition and threat to sue could have been extremely damaging, if not devastating. The Tribes certainly did not condone the irrigation districts' illegal water practices, but neither did they want to anger or alienate their partners and jeopardize their larger goals. At the same time, the Tribes needed to show concern for WaterWatch's petition and its correct allegations. Their strategy, recommended by Ed Chaney in a memo to the CTUIR board would be to

keep the pressure on BR and [irrigation] districts to clean up their acts without...playing into the hands of well-intentioned critics of the project who in their zeal for 'conservation' and for sticking it to BR and the irrigators for their past sins unwittingly would sacrifice the opportunity to enhance instream flows and thereby, would pit the tribe against the nontribal community. ${ }^{64}$

This public admonition at the irrigation districts, the Bureau, and OWRD would be for show. There was nothing for the Tribes to gain by "railing" (as Chaney put it) at 
the irrigators. Best to act "concerned," and let the state water resources department enforce compliance. ${ }^{65}$

There was also frustration and defiance on the Tribes' part. The Tribes could not wait for water, but the reforms in irrigating practices demanded by WaterWatch, while important in themselves, could take long for OWRD to implement. As Ed Chaney put it, "Contrary to what the good folks at Oregon Water Watch [sic] think, the tribe should not have to wait more decades for fulfillment of its treaty-reserved rights to fish until the state, $\mathrm{BR}$ and irrigators can get around to cleaning up their water-use act."

On December 5, representatives from the irrigators, the Bureau of Reclamation, OWRD, ODFW, WaterWatch, and the Tribes met to hammer out some sort of compromise to the WaterWatch petition. One source of irritation, and an example of how complicated these issues were, was that the Bureau had in fact been selling water from some of its improvements "illegally" to some irrigation districts without contracts. This was exactly the sort of thing what WaterWatch had complained of. But the Bureau defended itself, claiming it allowed this because of a prior agreement with the Westland Irrigation District. In 1984, it had agreed with WID to change the irrigation district boundaries. This legitimized the sale of Bureaucontracted water to the so-called Teel Irrigation District, since the new boundaries for WID would encompass the Teel Irrigation District. The Teel District would not be "outside" the boundaries any longer. 
In further meetings, these local, state, federal, tribal, and private groups negotiated desperately to keep the Project from derailing. Exacerbating the situation, the Water Resources Commission, a division of OWRD, voted to disallow water to be withdrawn by the Teel Irrigation District. ${ }^{67}$ Negotiations continued until February 1992, when the parties signed an agreement allowing the Umatilla Basin Project to go forward. WaterWatch, mollified by the prompt actions of the Bureau and OWRD, promised to make sure that it would not turn its petition into a suit that might cause Congress to withhold the promised funds.

$m m_{m} m$

WATER IS AND WILL ALWAYS BE THE MOST CONTENTIOUS RESOURCE in the American West. Its allocation and the competition of vying interests is harsh. In the Umatilla Basin, federal dollars and the reform of water allocation practices soothed these contentions. The new alliances were fragile, as the conflict over WaterWatch's petition shows. But in the end, these interests, who could hardly have less in common, agreed to back this project.

This is not to say that this alliance between Indians and irrigators was without tension or conflict. In the summer of 1992, the drought that hit the entire Pacific Northwest withered the plateau. In 1991, with the help of BPA, the Tribes had contracted with the Stanfield Irrigation District to release 3,000 acre-feet of its contracted water from McKay Reservoir in the spring for two purposes. First it flushed 2,000,000 smolts into the Columbia, and second it provided enough water for 
returning fish to find the Umatilla and ascend it to the spawning grounds. But panicked by the extent of the drought and in spite of the fact that it had no shortage of water, Stanfield reneged on its agreement with the Tribes. ${ }^{68}$ The Tribes finally got water from McKay, but it came from WID, and it came too late to save many of the fish struggling to return to the river. Thousands of smolts were wiped out despite efforts by tribal biologists to truck the small salmon down to the Columbia. After that horrendous summer, the Bureau of Reclamation started Phase II of the Project in the fall, but this illustrates how imperfect and contingent this alliance could be. Irrigation districts were in support of the Tribes as long as they did not have to give anything up themselves. Outside of curtailing their water-spreading activities, the irrigation districts have given up nothing throughout the entire process of Umatilla restoration. And yet the Tribes knew this going in. There is no documentary evidence that at any time the Tribes planned on moving the region or the local area toward a goal of equitable and ecologically benign water allocation.

The entities responsible for over-appropriating the river have, in the end, given up nothing. It was, again, the federal government, which generated the huge capital for a project that essentially purchasing the region's way out of crisis. The water that irrigators use still has to come from somewhere. As the conflict over water during the Drought of 1992 highlights, the fact that although the Umatilla Basin Project did give new meaning to fish programs, it still shows that when the chips are down, old ways still prevail. The issues are not settled, merely set aside through federal largess. 


\section{Chapter V-CONClusion: A River Won}

[M]y tribe cannot, and we have not, ever conceded or thought for a minute that salmon will not be in the Umatilla in one hundred years. We have developed our own restoration plan. While we do not say ours is the perfect plan, we do have some good concepts and a good philosophy. We have based it on science, but science is not going to solve all of our problems. We need the will to implement true salmon recovery.

-Don Sampson.'

$m m m$

ONE OF THE MAJOR THEMES IN ENVIRONMENTAL ACTION in the American West today is restoration. In the Umatilla River Basin, a combination of culture, law and policy, along with shifting alliances within resource extraction, produced an environmental success story: salmon have returned to the Umatilla River, where they spawn naturally after decades of absence. The restoration of anadromous fish still faces serious problems all over the region, both in the Columbia River Basin and coastal watersheds. But back in the 1980s, a story developed in Eastern Oregon where many new patterns originated, patterns that may help us conceive of new ways of salmon management today.

H

\section{The Necessity of the Tribes}

What the Umatilla story shows us above all else is that salmon restoration in the Columbia River Basin is simply not possible without a positive role for the 
Indian Tribes of the Mid-Columbia River, a role that they themselves define. There are two reasons for this. First, individual programs like the Umatilla are inconceivable without the Tribes and their powerful treaty rights. The treaties guarantee the Tribes a place in salmon management, and they use this role to focus on areas that other fish managers may ignore or overlook. Rather than choosing a stream because of its particular commercial or biological reasons, tribal managers establish a different set of criteria for choosing streams for rehabilitation based on the Tribes' cultural imperatives.

Second, the great cultural and historical significance of salmon to Columbia River Indians impels them to act. This history has forged in native people the will to keep more than a vestige of their culture alive and vital. In the highly charged political landscape of salmon restoration, where public will takes long to translate into political will and action, the signatory tribes of the Treaties of 1855 are a positive force that continue to redirect energy and attention to what is really important: the preservation and integrity of this crucial element of Northwest ecosystems.

It has not always been this way. For many years, those treaty rights lay moribund, ignored, flouted by the fish and wildlife agencies of the Columbia Basin. But since the 1960s, the Tribes have made themselves major players by relying on legal interpretations of the treaties legal from the Winans decision to Judge Orrick's ruling in Phase II of United States v. Washington, and the statutory obligations to the Northwest Power Act. This is not to say that the Tribes dictate policy, or even have 
all of their programs implemented. Many of the Tribes' wishes and demands are either still ignored or fought against by various factions. Some environmental groups oppose the supplementation programs on the grounds of the possible harm they do to wild fish. Many Direct Service Industries question the Tribes' motives, claiming that they are just another river interest using the treaties as a screen to catch endangered fish. Fishery managers, struggling for funds, find themselves in competition with the Tribes for hatchery money and for control of the fishery. The Bonneville Power Administration, in an attempt to maintain control over a system it has co-managed for 50 years, has fought to keep the expensive Fish and Wildlife Program under its sway. And the Tribes still have no seat on the Northwest Power Planning Council.

The value of the Tribes to salmon restoration goes beyond the rehabilitation of rivers that flow through their reservations, like the Umatilla and the Yakima. Tribal influence extends to the ceded lands and rivers, also. Armed with fishing rights reserved in the Treaty of 1855 , the Umatillas have spearheaded restoration efforts on other ancestral streams, like the Walla Walla and the Grande Ronde. Only the Tribes, with the treaties and the Winters Doctrine could have gotten an increase of water to the Umatilla Basin through the Umatilla Basin Project. Only the Tribes could have forced the irrigation districts to get on board to support the Umatilla Basin Project. And only the Tribes had the passion and vision to look at a sink of agricultural waste and see the Umatilla as something vivacious and alive.

A quick review of other agencies and interest groups show that without the Tribes, the Umatilla River would probably remain a dead river. No environmental 
group could have restored salmon on the Umatilla. Given the fact that few environmental organizations have capital sufficient for such an undertaking, it is highly unlikely that any would take on such a project. The river has no special status, and it would not qualify for any grants from the government. Also, the Endangered Species Act played no role: Umatilla chinook and coho were not endangered, they were extinct. The only way this sort of project could be employed on this river is by the Confederated Tribes of the Umatilla Indian Reservation. Only CTUIR's sovereign interest could have made the Umatilla River a candidate for salmon restoration.

The Oregon Department of Fish and Wildlife had no plans for any fish projects on the Umatilla before approached by the Tribes for assistance. ODFW responded quickly with technical assistance and planning. While it was the Tribes' major partner in this story, it is clear that the wholesale revival of chinook to the Umatilla was far beyond the scope of ODFW's vision. Similarly, the federal agencies with jurisdiction over fish, the National Marine Fisheries Service and the U.S. Fish and Wildlife Service, did not have this sort of restoration in their plans. These two agencies might have had the legal capacity and the technical skill to put such reintroduction programs into effect, but such restoration was not on those agencies agendas.

Finally, it is difficult to see any organization in the state or region rehabilitating the Umatilla because it looked so bad. During the time of highest use the dried, desiccated lower river looked as if someone had used it to grow algae 
commercially, then abandoned the project. Where there was water it was a series of green ponds that moved sluggishly, if at all. There was simply no habitat for anadromous fish. Only the Confederated Tribes of the Umatilla Indian Reservation could have cared enough about such a river to commit such will and effort into reestablishing it as a cold water habitat for salmonids. Don Sampson says that he remembers the stories of old-timers who would gaff-hook salmon from the Umatilla to take home. ${ }^{2}$ To look at such a river with reaches of sun-bleached algae and cattle manure and see free-swimming fish migrating powerfully upriver, dancing the mating ritual, digging redds for spawning, and being caught by one's people is to take heart from such stories.

Far from being an historical afterthought, the Indians of the Columbia Plateau are an intrinsic part of the river. Ties that defy easy classification connect them to the Columbia and its tributaries. The powerful cultural values Indians attach to salmon fuel the will needed to confront state agencies and the federal bureaucracies that run the river. The Treaties of 1855 and the Northwest Power Act provided the legal tools for restoration, and the Tribes provided the will. The benefit of strong salmon and steelhead runs to tribal fishers is bound up in a combination of prosperity, sustenance, and spirit. The Plateau Peoples have been nothing if not stubborn in their insistence that there be salmon in the rivers, and this stubbornness has today translated itself into political will. 


$$
\text { tet }
$$

\section{Ossified Agencies}

Committing will to these kinds of projects means committing money. Passage of the Northwest Power Act provided the financial opportunity to rehabilitate the Umatilla. In the early 1980s, the Council committed itself to changing the mindset of engineering efficiency that had run the river since the Corps built Bonneville Dam. It backed up the attitude with large amounts of money. Without these funds, only a major appropriation from Congress could have made the $\$ 20$ million Umatilla Program feasible.

The Council's commitment to change showed its adoption of the new terminology of river biology. It would support projects it considered biologically sound, and it would require such projects be executed in the most cost effective way possible. The Umatilla Program was among the first large restoration efforts endorsed by the Council, and to pay for it, the Council turned to the Bonneville Power Administration, per the Northwest Power Act. When the Council directed BPA to pay for the Umatilla Program, it was establishing the precedent that the Council did have such power to direct BPA's release of funds.

This turned out to be much more difficult than imagined. For five years, BPA resisted funding of the Umatilla program, in spite of the directive of the Northwest Power Act. The names that consistently appear in the documentation of BPA's struggle to control the Umatilla Program's funding are the Fish and Wildlife Division's head, John Palensky, and the Umatilla program manager, Tom Vogel. 
Palensky and Vogel did all they could to control or derail the Umatilla Fisheries Restoration Program. These two even hinted that BPA was not required to fund any project that did not meet the Division's criteria; criteria that remained vague the entire time Vogel remained program manager. When the Tribes, ODFW, and the Council convinced Bonneville to change personnel and move on the Program, they forced BPA to accept its role as prime funding agency for the Columbia River Basin Fish and Wildlife Program.

Salmon management will always be affected by personalities. A recalcitrant administrator in the wrong place at the wrong time can delay, or perhaps even destroy, a project. But this event speaks to more. It shows how the agencies runing the Columbia River system has ossified into a way of seeing the river that is now obsolete. Bonneville changed structurally and formed a Fish and Wildlife Division, ostensibly to facilitate the Council's objectives. But conceptually, BPA's ideas on the river were the same. In fact, it is not clear why Bonneville has such a division. One must ask, if the Northwest Power Act specifically prevents NPPC from becoming "a super fish and wildlife agency," why should the Council's funding agency set up such an agency? What could the staff in such an agency (where many of the project managers are not even biologists) possibly add to the store of scientific knowledge amassed by state, federal, tribal, and Council biologists over the past 30 years? The Umatilla story suggests a reason: to retain as much control over the Fish and Wildlife Program as possible. 
The Northwest Power Act was not specifically established to ensure fishing rights, and yet the Northwest Power Planning Council's support for the Umatilla Program did just that. In the Council's 1984 version of the Columbia River Basin Fish and Wildlife Program from 1984, Section 106 states that the Council's actions must be "consistent with the legal rights of Indian tribes."” The Council clearly saw that funding a program that would enhance tribal (as well as non-tribal) fishing was consistent with the Tribes' treaty rights. Within the last ten years some tribal managers and environmentalists have complained that the Council has become politicized, a turn that means anadromous fish in the region may not get the kind of help they need from the entity most able to orchestrate recovery. But in the early 1980 s its commitment was strong. ${ }^{4}$

\section{HEx}

\section{Alliances Old and New}

The last of the major lessons of the this story is the realignment of traditional antagonists into the new alliances that promoted, built, and operated the new fish facilities and the immense water project that sustains them.

First is the change between the Tribes and Oregon Department of Fish and Wildlife. Traditionally, Indian tribes and state agencies have clashed over natural resource issues like hunting and fishing. The past behavior of Oregon's and Washington's fish and game agencies did not bode well for this sort of alliance. ${ }^{5}$ The Oregon Department of Fish and Wildlife assisted the tribal program with much 
needed technical expertise and provided some of the most important studies of the Umatilla Basin. ${ }^{6}$

The other transition of allegiances was the shift of the irrigators in the Umatilla Basin to support the Tribes in calling for the Umatilla Basin Project of 1989. In fact, the re-watering of the Umatilla River may be the most remarkable aspect of the whole story. This is not because of the money, although the Umatilla Basin Project cost over $\$ 46$ million, more than twice what the Umatilla Fish Restoration Program cost Bonneville. Nor is the scale the most impressive part of the story, although the transfer of so much water from the Columbia to irrigators over so many square miles is also remarkable. What makes this so interesting is the break of the irrigators from their alliance with other river users and their entering a new alliance with the Indians. Traditionally, farmers, barge operators, and the utilities have spoken with one voice on issues of river use. But in this case, farmers split with the utilities over the issue of BPA's involvement in the Project and joined the Tribes. The Pacific Northwest Utilities Conference Committee, BPA's chief constituent, fought to detach BPA from any obligations to what it saw as an irrigation project, not a fish restoration project. The Pacific Northwest Utilities Conference Committee, BPA's chief constituent, fought to detach BPA from any obligations to what it saw as an irrigation project, not a fish restoration project. PNUCC also opposed the fisheries program, as evidenced by its contracting a biological report on the Umatilla Basin. In a letter from the biologist commissioned to study the Program for PNUCC, the biologist wrote that the 
[e]conomic costs...should be compared to benefits....[I] cannot walk in the economists boots, but I can say that I think that even my lowered expectation of returns from hatchery releases will prove too high. ${ }^{7}$

Thus, according to PNUCC's hired expert, the Umatilla Program should be subjected to a cost-benefit analysis. PNUCC was obviously unhappy with the defection of irrigators to the Indians, but the irrigators understood that although the Tribes did not wish to press litigation under the Treaties nor the Winters Doctrine, they still possessed the legal high ground. The farmers who depended on the Umatilla River could not afford the crippling loss of their water rights.

Political realignment also included environmentalists. It is unusual that an environmental group opposes a project whose stated goal is to restore nature. Yet that is exactly what the Tribes faced when WaterWatch of Oregon attacked the project as a giveaway to irrigation interests, what they saw as pork-barrel projects for irrigators wrapped in "an Indian blanket." WaterWatch had a point: irrigators gave away nothing in this transaction. They retained their water rights and water. In many ways, irrigators were the prime beneficiaries of the Umatilla Basin Project. WaterWatch's charges could not be refuted: the documentary evidence shows Oregon Water Resources Department knew its own regulations were being flouted. Forcing OWRD and the Bureau of Reclamation to crack down on water law provided WaterWatch with a limited victory: the Umatilla Basin Project would benefit the new salmon. But it certainly did not force the region to directly confront the issues that had killed off anadromous fish in many Plateau rivers. 
The Umatilla still does not flow year-round to the Columbia. As Dave Duncan, the Bureau of Reclamation's planning manager for the Umatilla Basin Project, has said: "To keep the Umatilla flowing all year long would take an incredible amount of water." ${ }^{18}$ Nonetheless, there is enough water flowing between Threemile Dam and the mouth at crucial times to facilitate the migration of Umatilla River chinook and coho. Many fish are captured and spawned artificially, but these offspring are reared part-time in natural ponds that allow them to imprint on a real river. Salmon and steelhead still cannot swim all the way to their spawning grounds, but they do spawn naturally after tribal fish technicians trap and release them upstream. This combination of nature and artifice epitomizes the complexity of restoring a key piece of the environment in the Umatilla River Basin. It also highlights still-existing problems acknowledged but not yet approached.

Despite the success of reintroducing water for Umatilla salmon, the Umatilla Basin Project has limited value as an example a basin-wide solution to irrigationbased habitat destruction. The struggle between seeing water as a utility for crops versus water as the life-blood of a living river, the issue initially destroyed the Umatilla runs, was not solved, but merely sloughed off to another part of the Columbia River system. This is merely a shift of appropriation, not a solution. While it did partially solve the Umatilla dilemma, it is not a practical regional solution to repairing the contributions of irrigation to the salmon crisis. ${ }^{9}$ For example, irrigation also did grave damage to salmon runs in Yakima River. The over-appropriation of water in this sub-basin so much larger than the Umatilla, and so much farther 
geographically from the Columbia, suggests that there could never be a "Yakima Basin Project." Assuming that irrigation-ravaged sub-basins like the Yakima or the Grande Ronde were closer to a source of water like the Columbia, what of overappropriating the Columbia itself? Even if the money existed to re-water every single sub-basin in the Plateau affected by irrigation, even if topography allowed the construction of a dozen Umatilla-type projects, the Columbia is simply not capable of providing that much water.

Obviously, each local area must seek a unique, local solution. But what must be universal is a regional agreement on over appropriating water. Salmon require a more radical solution than just getting money from the federal government and the mentality we can have it all, that there is enough water to have abundant salmon runs and unlimited land under irrigation. It was this mentality that brought this society the salmon crisis to begin with.

This cornucopian attitude was at play in the Umatilla. Symbolizing this mentality is the graphic on the header of the official stationary of the Umatilla Basin Project Steering Committee. Printed on the top all of its of their official memoranda is a chinook salmon in the upper left corner and a center-pivot irrigation swing in the right. While in one way this represents the new alliance of fish and irrigation interests, a co-existence of antagonistic views on the Columbia, it nonetheless shows an attitude of complacence: the participants dodged the fundamental issue of living within one's means. Without the extensive resources of the federal government and the most powerful river in the world at their doorstep, this illusion of abundance 
would be farcical. These two vast resources allowed the Umatilla Basin to keep the status quo of water resource extraction. This fact restrains the usefulness of the Umatilla Fish Restoration Program as a "model" restoration plan that could be duplicated throughout the Columbia River Basin.

The Confederated Tribes did not challenge the way water is allocated in the Columbia Basin. They too had much to lose in a direct challenge, but fish advocates and environmentalists might ask what if the Tribes had challenged and won? What would have happened to water on the Columbia Plateau? The possibility that the Sahaptin-speaking tribes of the Columbia Plateau could control and allocate water based on the needs of ecosystems rather than cash crops is nothing less than revolutionary.

Despite the issues unsolved, this story shows that with the will, Pacific Northwesterners can check and reverse the declines of anadromous fish in the Columbia Basin. With native peoples leading the way, forging unlikely, fragile alliances, restoration is possible. Given a reliable source of money and water, with concern for biology as an equal to economics, and no interference from agencies at odds with the goals of the Columbia River Basin Fish and Wildlife Program, salmon restoration in the sub-basins of the Columbia River Basin is not only possible, but within the grasp of a single generation. 
A RIVER MAY NOT SEEM "RATIONAL" TO AN ENGINEER, but science has shown that rivers move along their own lines, following a rationale all their own. These lines are more complex than we can possibly imagine, and so appear chaotic or irrational. But more than a hundred years ago, Americans began to remake the rivers in the West into images that conformed to their sense of "rational": that the rivers should do work for them-irrigate farms, transport freight, generate power. From 1905 to 1926, farmers and the U.S. Bureau of Reclamation used technology to rationalize a river that did not belong to them, but rather to an Indian tribe. Irrigators subdued the Umatilla River to make the plateau burst forth in a profusion of crops. But in doing so, they obliterated the river's life force, the salmon. Years later, the Confederated Tribes of the Umatilla Indian Reservation and the Bureau of Reclamation used technology to re-naturalize part of that river, to resurrect it from a vale of farmers' waste and chemical sludge to a salmon stream.

The fate of Pacific salmon in the Columbia River Basin is far from clear. Today Pacific Northwesterners are faced with crucial and divisive issues that will determine whether or not these remarkable animals continue to swim into the interior to spawn. There is a baffling amount of information, generated by biologists and economists hired by both industries that wish no changes in the status quo of river operations, and by environmental organizations committed to radical alterations on the river in the name of biology. Somewhere in between are disinterested scientists who do not always agree on the correct course for society to take. 
What is encouraging in the Umatilla is that many disparate groups were able to forge an agreement that would bring salmon back to a dead river. Many of these groups were traditional adversaries, like the Confederated Tribes and the State of Oregon. Also, when other river-users became involved to stop the agreement, the Tribes and their allies were able to keep the discussion focused on the river and the salmon, rather than the money BPA was spending.

There is conflict in the Pacific Northwest over different visions and expectations of what the Columbia River system is supposed to be. Is the system a hydroelectric generator, irrigator, transportation artery, an engine of commerce? Or is it the dynamic core of a larger biotic community, part a living system that includes both people and animals? This story reveals changes in the relationships of political and social power in the struggle to control the destiny of the Columbia River system, and how one group used this new power to advance its own vision of the midColumbia country.

On several levels, the success in the Umatilla Basin is indicative of what could be accomplished throughout the Columbia River Basin. Given enough money, water, and will, many distressed river systems in the Columbia Basin can be rehabilitated, made healthy again with free-spawning salmon.

What this work has tried to do is tell a story of a river restored by people who remembered the old life of the river. Barry Lopez writes that the most effective stories we tell are not the ones that purport to "teach." Such stories are merely pedantic. What we actually derive from stories is subtler: 
Stories do not give instruction, they do not explain how to love a companion or how to find God. They offer, instead, patterns of sound and association, of event and image. Suspended as listeners and readers in these patterns, we might reimagine our lives. It is through story that we embrace the great breadth of memory, that we can distinguish what is true, and that we may glimpse, at least occasionally, how to live without despair in the midst of the horror that dogs us and unhinges us. ${ }^{10}$

The memory of the Umatilla, Walla Walla, and Cayuse people is long. They did not despair. They listened to their stories, both mythological and recent; ancient stories about Coyote's adventures in the land, and the fishing stories of their grandfathers. Out of these stories they reimagined their river resurrected, and in doing so they refused to accept that their traditions and culture could be shattered beyond recall. By examining the patterns that arise from this new type of restoration and these new types of alliances, this story has tried to show that Pacific Northwesterners have but to reimagine the Columbia River and its tributaries, and decide what sort of a river we want. Then to pursue that image with a will. 


\section{Endnotes}

\section{Notes to Chapter I}

1979), 134.

'Barry Lopez, "Drought," in River Notes: The Dance of Herons (New York: Avon Books,

${ }^{2}$ Joseph Cone, A Common Fate: Endangered Salmon and the People of the Pacific

Northwest (Corvallis: Oregon State University Press, 1996), 236.

${ }^{3}$ Hereafter, the Confederated Tribes, or simply "the Tribes."

${ }^{4}$ Eugene S. Hunn, with James Selam and Family, Nch'i-Wána, "The Big River": Mid-

Columbia Indians and Their Land (Seattle: University of Washington Press, 1990); Fay G. Cohen, Treaties on Trial: The Continuing Controversy over Northwest Indian Fishing Rights (Seattle: University of Washington Press, 1986); Charles F. Wilkinson, Crossing the Next Meridian: Land, Water, and the Future of the West (Covelo: Island Press, 1992), 175-218; Joseph Cone, A Common Fate: Endangered Salmon and the People of the Pacific Northwest (Corvallis: University of Oregon Press, 1996), 234-242.

${ }^{5}$ United States Department of State, "Treaty With The Wallawalla, Cayuse, and Umatilla Tribes," 9 June 1855, in Charles J. Kappler, Indian Affairs: Laws and Treaties, Volume II, Treaties (Washington: U.S. Government Printing Office, 1904), 694-698; Cohen, Treaties on Trial.

${ }^{6}$ Joseph Cone, A Common Fate: Endangered Salmon and the People of the Pacific Northwest (Corvallis: University of Oregon Press, 1996), 234-242.

${ }^{7}$ United States v. Washington, 384 F. Supp. 312 (1974), hereafter the Boldt decision.

${ }^{8}$ Roberta Ulrich, "Justice Delayed: A Sixty Year Battle for Indian Fishing Sites" (MA thesis, Portland: Portland State University, 1996); Don Sampson, "Who Runs the Reservoirs?"

Environmental Law 26, 686-689.

${ }^{9}$ Carl Riesland, "Old Timer Says Fishing Isn't What it Used to Be...," Oregon Journal, 24 April 1931, 4; Independent Scientific Group, Return to the River: Restoration of Salmonid Fishes to the Columbia River Ecosystem (Portland: Northwest Power Planning Council, 1996), 377-398..

${ }^{10}$ The Mitchell Act, 52 Stat. 345 ( $75^{\text {th }}$ Cong., $3^{\text {rd }}$ Sess., 11 May, 1938); Cohen, Treaties on

Trial; Douglas W. Dompier, "Commentary," in The Northwest Salmon Crisis, Joseph Cone and Sandy Ridlington, 199-215.

${ }^{11}$ Paul C. Pitzer, Grand Coulee: Harnessing a Dream (Pullman: Washington State University Press, 1994), 223-224.

${ }^{12}$ Letter from Dale R. Evans, Division Chief of the National Marine Fisheries Service, to Elwood Patawa, Chaiman, Board of Trustees of the Confederated Tribes of the Umatilla Indian Reservation, April 9, 1984. Evans requested that the Tribes quantify their religious practices in dollar terms so that NMFS could do a cost-benefit analysis on their request for hatchery fish to put in the Umatilla.

${ }^{13}$ Donald Worster, Rivers of Empire: Water, Aridity, and the Growth of the American West (New York: Oxford University Press, 1985), 97, 170-171.

${ }^{14}$ U.S. Bureau of Reclamation, Bureau of Reclamation Feasibilities and Authorizations: A Compilation of Findings of Feasibilities and Authorizations for Bureau of Reclamation Projects of the Department of the Interior (Washington, D.C.: U.S. Government Printing Office, 1957), 891-896, 998-1024.

${ }^{15}$ United States Bureau of Reclamation, "Umatilla Project, Oregon: Morrow and Umatilla Counties" (Boise: U.S. Bureau of Reclamation, project data book, 1983). In a minor twist of irony, the Bureau of Reclamation then made the lands around McKay a wildlife refuge.

${ }^{16}$ Elmer Dodd papers, MSS\# 1601, Box 1 of 3, 1933, Oregon Historical Society.

${ }^{17}$ Paul Koberstein, "The Umatilla River Blues," October 16, 1991, The Oregonian, B01. 
${ }^{18}$ Raymond R. Boyce, Final Report: A Comprehensive Plan for Rehabilitation of Anadromous Fish Stocks in the Umatilla River Basin (Portland: Bonneville Power Administration, 1985), 11.

${ }^{19}$ Pitzer, Grand Coulee, 14-36.

${ }^{20}$ Ibid., 35.

${ }^{21}$ Ibid., 14-36; "Resolution to the Umatilla Rapids Dam on the Columbia River," Umatilla Rapids Association, July 17, 1933, Dodd papers, MSS\# 16, Box 3 of 3, Oregon Historical Society; William L. Lang, "River of Change," in The Northwest Salmon Crisis, Joseph Cone and Sandy Ridlington, eds., 355.

${ }^{22}$ William Dietrich, Northwest Passage: The Great Columbia River (New York: Simon and Schuster, 1995), 52-57. 1934.

23 “Columbia River and Minor Tributaries," H.R. Doc. No. 103, Vol. 2, $73^{\text {rd }}$ Cong., $1^{\text {st }}$ Sess.

${ }^{24}$ Keith Petersen, River of Life, Channel of Death: Fish and Dams on the Lower Snake (Lewiston: Confluence Press, 1995); Lang, "River of Change," 356-358; Richard White, The Organic Machine: The Remaking of the Columbia River (New York: Hill and Wang, 1995).

${ }^{25}$ Pitzer, Grand Coulee, 215, 223-230. Pitzer has downplayed this disaster. "June Hogs" were upper-Columbia Spring chinook that could weigh between 40 and 125 pounds.

${ }^{26}$ Ed Chaney and L. Edward Perry, Columbia Basin Salmon and Steelhead Analysis: Summary Report (Portland: Pacific Northwest Regional Commission, 1976), 6-7; William F. Willingham, Army Engineers and the Development of Oregon: A History of the Portland District of the U.S. Army Corps of Engineers (Washington, D.C.: Government Printing Office, 1983) 197; In 1973 , as many as $95 \%$ of chinook and steelhead smolts passing downstream were killed at Little Goose Dam on the Snake River. Howard L. Raymond, "Effects of Dams and Impoundments on Migrations of Juvenile Chinook Salmon and Steelhead from the Snake River, 1966 to 1975," Transactions of the American Fisheries Society 108 (November 1979): 505-529.

${ }^{27}$ Public Law No. $75-502$, ch. 193, 52 Stat. 345 (1938). For a more thorough discussion of the Mitchell Act's role in the salmon crisis, see Chapter II.

${ }^{28}$ Pacific Northwest Electric Power Planning and Conservation Act, Pub. L. 96-501, §4(h), 94 Stat. 2697 (1980). (Hereafter, the Northwest Power Act.) "the Council.")

${ }^{29}$ Ibid., §4(a)(1), 2700. (Hereafter, the Northwest Power Planning Council, NPPC, or simply

${ }^{30}$ Ibid., $\$ 4(\mathrm{~h})(11)(\mathrm{A})(\mathrm{i}), 2710$. (Emphasis added.)

${ }^{31}$ Ibid., \$4(h), 94 Stat. 2697, 2710 (1980).

${ }^{32}$ Michael C. Blumm and F. Lorraine Bodi, "Commentary," in Joseph Cone and Sandy Ridlington, eds., The Northwest Salmon Crisis: A Documentary History (Corvallis: Oregon State University Press, 1996), 263. CRITFC is comprised of the four Plateau Tribes that signed the 1855 treaties: the Nez Perce, the Yakama, the Warm Springs, and the Umatilla.

${ }^{33}$ Lang, "River of Change," 358.

${ }^{34}$ Michael C. Blumm, "Implementing the Parity Promise: An Evaluation of the Columbia Basin Fish and Wildlife Program," Environmental Law 14 (1984): 277-358.

${ }^{35}$ Northwest Power Act, $\S 4(\mathrm{~h})(6)(B), 2709$; Blumm, "Implementing the Parity Promise": 284-285.

${ }^{36}$ Ibid., $\S 4(\mathrm{~h})(10)(\mathrm{A}), 2710$.

${ }^{37}$ Jonathan Brinckman, Oregonian, 27 July 1997, A01.

${ }^{38}$ The Northwest Power Planning Council, Columbia River Basin Fish and Wildlife

Program, (Portland: Northwest Power Planning Council) 1982, § 704(i)(1), 46.

${ }^{39}$ Ibid., 11-12.

${ }^{40}$ Ibid., 12.

${ }^{41}$ Ibid., 13.

${ }^{42}$ The Northwest Power Planning Council, Columbia River Basin Fish and Wildlife

Program, (Portland: Northwest Power Planning Council) 1982, § 106, 6. 
${ }^{43}$ Northwest Power Act, $\S(\mathrm{h})(1)(\mathrm{A}), 2708$. (Emphasis added.)

${ }^{44}$ Northwest Power Planning Council, Columbia River Basin Fish and Wildlife Program, $\S 702,45 ; \S 704,47$.

${ }_{45}$ Brian T. Meehan and Joan Laatz Jewett, "River of Ghosts," Sunday Oregonian, 29

October 1995, sec. S.

${ }^{46}$ Joseph Cone and Sandy Ridlington, eds., The Northwest Salmon Crisis: A Documentary History (Corvallis: University of Oregon Press, 1995), iv; Joseph E. Taylor, III, "Making Salmon: Economy, Culture, and Science in the Oregon Fisheries, Precontact to 1960" (Ph.D. diss., University of Washington, 1996), 2-3; Lang, "River of Change," 348.

${ }^{47}$ Jenniger Phillips, Jill Ory, and André Talbot, "Anadromous Salmonid Recovery in the Umatilla River Basin, Oregon: A Case Study," in Journal of the American Water Resources Association 36 (2000), 1295.

${ }^{48}$ Hunn, N'chi Wanna.

\section{Notes to Chapter II}

'Elizabeth Woody, "The English in the Daughter of a Wasco/Sahaptin Woman, Spoken in the Absence of Her Mother's True Language," in Luminaries of the Humble (Tucson: University of Arizona Press, 1994), 107.

${ }^{2}$ Elizabeth Woody, "Wyam: Echo of Falling Water," in Seven Hands, Seven Hearts (Portland: Eighth Mountain Press, 1994), 63-64; Taylor, "Making Salmon," 30.

${ }^{3}$ Cone, A Common Fate, 50-59.

${ }^{4}$ United States $v$. Washington, 506 F. Supp. 187.

${ }^{5}$ Steelhead are sea-run rainbow trout. They are virtually indistinguishable genetically from resident rainbows. See Judith Stoltz and Judith Schnell, eds., Trout (Harrisburg: Stockpole Books, 1991), 324; J.C. McKern, "Steelhead Trout Otholiths" (MA thesis, Portland State University, 1996).

${ }^{6}$ The Umatilla River Basin lacks the lakes required by sockeye salmon for spawning.

${ }^{7}$ Vine Deloria, Jr., "Power and Place Equal Personality," in Indian Education in America

(Boulder: American Indian Science and Engineering Society, 1991), 14.

${ }^{8}$ Ibid.

${ }^{9}$ Randall F. Schaulk, "Estimating Salmon and Steelhead Usage in the Columbia Basin

Before 1850: The Anthropological Perspective," Northwest Environmental Journal 2 (1986), 2-23; Taylor, "Making Salmon," 29.

${ }^{10}$ Ibid., 30.

"Woody, "Wyam: Echo of Falling Water," 63-64.

${ }^{12}$ R.W. Schoning, T.R. Merrel Jr., D.R. Johnson, The Dip Net Fishery at Celilo Falls on the Columbia River (Portland: Oregon Fish Commission, 1951), 5.

${ }^{13}$ Taylor, "Making Salmon," 53-56.

${ }^{14}$ Ibid., 53.

${ }^{15}$ Woody, "Wyam: Echo of Falling Water," 64.

${ }^{16}$ Hunn, N'chi Wanna, 153.

${ }^{17}$ Taylor, "Making Salmon," 37-51.

${ }^{18}$ Ibid., 51-56. Hunn makes no connection whatever between salmon and the religion of the Plateau People.

${ }^{19}$ Sampson, "Who Runs the Reservoirs?" 687-691.

${ }^{20}$ Hunn, N'chi Wanna, 280-281

21 "Treaty With The Wallawalla, Cayuse, and Umatilla Tribes," 9 June 1855, in Kappler, 695; Hunn, 45, 84.

${ }^{22}$ United States v. Winans, 198 U.S. 371, 381 (1905); Robert Miller, "Speaking with Forked Tongues: Indian Treaties, Salmon, and the Endangered Species Act," Oregon Law Review 70 (Fall 1991): 3, 552 . 
23 "Minutes of the Treaty of Point-No-Point" (Dec. 26 1854, 12 Stat. 933), reprinted in Cone and Ridlington, The Northwest Salmon Crisis, 177.

${ }^{24}$ Kent D. Richards, "Historical Antecedents to the Boldt Decision," Western Legal History: The Journal of the Ninth Circuit Historical Society 4 (Winter/Spring 1991): 80-81.

${ }^{25}$ Taylor, "Making Salmon," 27-28.

${ }^{26}$ William G. Robbins, "The World of Columbia River Salmon: Nature, Culture, and the Great River of the West," in Cone and Ridlington, The Northwest Salmon Crisis, 10.

${ }^{27}$ United States $v$. Winans, 198 U.S. 371(1905).

${ }^{28}$ Ibid., 664.

${ }^{29}$ Winters $v$. United States, 564 U.S. 207, 211-212 (1907).

${ }^{30}$ Cohen, Treaties On Trial, 11-17, 77-80; .Michael Blumm, "The Indian Treaty Fishing

Right To Habitat Protection," The Big River News 4 (Portland: Northwestern School of Law of Lewis and Clark College, 1998), 11.

${ }^{31}$ Washington v. Passenger Fishing Vessel Association, 99 S.Ct. 3055, 3069 (1977).

${ }^{32}$ Ibid., 3061.

${ }^{33}$ Cohen, Treaties on Trial, 83-106.

${ }^{34}$ United States $v$. Washington, 506 F. Supp. 187, 203; Michael C. Blumm and F. Lorraine Bodi, "Commentary," in Cone and Ridlington, eds., Northwest Salmon Crisis, 195-196.

${ }^{35} 759$ F.Supp. 1353, 1360 (1985).

${ }^{36}$ United States $v$. Washington; see Cohen, Treaties on Trial, 106.

${ }^{37}$ Winters $v$. United States 564 U.S. 207, 212 (1907).

${ }^{38}$ Roberta Ulrich, Empty Nets: Indians, Dams, and the Columbia River (Corvallis:

University of Oregon Press, 1999), 80-97; Elizabeth Woody, "Wyam: Echo of falling Water," 63-64.

${ }^{39}$ Taylor, "Making Salmon,"157, 271-281.

${ }^{40}$ Courtland Smith, Salmon Fishers of the Columbia (Corvallis: Oregon State University Press, 1979), 81 .

${ }^{41}$ Oregon Department of Fish and Wildlife, Status Report: Columbia River Fish Runs and Fisheries, 1938-1993, 1994.

${ }_{42}$ Taylor, "Making Salmon," 239-304.

${ }^{43}$ Robbins, "The World of Columbia River Salmon," 13. (Emphasis in original.)

${ }^{44}$ Smith, Salmon Fishers of the Columbia, 91-100.

${ }^{45}$ Taylor, "Making Salmon," 107, 108.

${ }^{46}$ Gordon B. Dodds, Salmon King of Oregon: R.D. Hume and the Pacific Fisheries (Chapel Hill: University of North Carolina Press, 1959), 137; Taylor, "Making Salmon," 318-319.

${ }^{47}$ Livingston Stone, "Explorations on the Columbia River from the Head of Clarke's Fork to the Pacific Ocean, Made in the Summer of 1883, with Reference to the Selection of a Suitable Place for Establishing a Salmon-breeding Station," in United States Commission of Fish and Fisheries, Report of the Commissioner for 1883 (Washington, D.C.: Govt Printing Office, 1885), 242, 244; Bill Bakke and Joseph Cone, "Commentary" in Cone and Ridlington, eds., Northwest Salmon Crisis, 4647; Taylor, "Making Salmon," 120-126, 173.

${ }^{48}$ Taylor, "Making Salmon," 123.

${ }^{49}$ Ibid., 109.

${ }^{50}$ Independent Scientific Group, Return to the River: Restoration of Salmonid Fishes in the Columbia River Ecosystem (Portland: Northwest Power Planning Council, 1996), 407; Ray J. White, James R. Karr, and Willa Nehlsen, "Better Roles for Fish Stocking in Aquatic Resource Management," Journal of the American Fisheries Society 15 (1995): 527-547.

${ }^{51}$ Ibid.

${ }_{53}^{52}$ Independent Scientific Group, Return to the River, 70-82.

${ }^{53}$ Ibid.

${ }^{54}$ Taylor, "Making Salmon," 134-135, 145, 151.

${ }^{55}$ Ibid., 211.

${ }^{56}$ Mitchell Act, Public Law No. 75-502, ch. 193, 52 Stat. 345 (1938). 
${ }^{57}$ Petersen, River of Life, Channel of Death, 169; amendment to the Mitchell Act, U.S. Congress, Public Laws, Chapter 883, 932.

${ }^{58}$ Robert Duncan, Member, Northwest Power Planning Council, Before Subcommittee on Water and Power Committee on Energy and Natural Resources at a Hearing on S. 1613, Pendleton, Oregon, February 8, 1988.

${ }^{59}$ Independent Scientific Group, Return to the River, 399 (citing the Regional Assessment of Supplementation Program (RASP), 1992, 6).

${ }^{60}$ White, et al., "Better Roles for Fish Stocking," 535. These definitions are my contrivance. By the "official definition" of supplementation outlined in Independent Scientific Group, Return to the River, the Umatilla project is technically a supplementation project. But I feel this would confuse the issue too much since the Umatilla program is quite different (and much less controversial) than the Yakima River program.

${ }^{61}$ Taylor, "Making Salmon," 378.

${ }^{62}$ Columbia River Inter-Tribal Fish Commission, Wy-Kan-Ush-Mi Wa-Kish-Wit: The Spirit of the Salmon, Executive Summary (Portland: Columbia River Inter-Tribal Fish Commission, 1996), 9 .

${ }^{63}$ Ibid.

${ }^{64}$ Northwest Power Planning Council, Columbia River Basin Fish and Wildlife Program, 13; Dompier, in The Northwest Salmon Crisis, 203.

${ }^{65}$ Ed Galindo and Ben Rinehart, Indian Summer IV: Student Streamside Incubation Project, 1998 (Fort Hall: Shoshone-Bannock Fisheries Department, 1998), 10-13; Columbia River Inter-Tribal Fish Commission, Wy-Kan-Ush-Mi Wa-Kish-Wit, 7.

${ }^{66}$ Douglas W. Dompier, "Commentary," in Cone and Ridlington, The Northwest Salmon Crisis, 213-215; Memorandum from Samuel L. Hutchinson, Acting Regional Director, Bureau of Commercial Fisheries, 16 January, 1951 (Portland: Columbia River Inter-Tribal Fish Commission archives, photocopy).

${ }^{67}$ Independent Scientific Group, Return to the River, 75.

${ }^{68}$ White, et al., "Better Roles for Fish Stocking," 527-547.

${ }^{69}$ Ibid.

${ }^{70}$ Richard Cockle, "Indians to 'Abduct' Salmon as Protest," the Oregonian, May 16, 1992,

B8.

${ }^{71}$ Ibid.

\section{Notes to Chapter III}

' Donald Worster, Rivers of Empire, 58.

${ }^{2}$ Northwest Power Act, § 4(h)(1)(A), 2708.

${ }^{3}$ Northwest Power Planning Council, "Notice of Proposed Amendments to the Columbia River Basin Fish and Wildlife Program Regarding the Umatilla River Flow Enhancement," July 14, $1988,1$.

${ }^{4}$ United States v. Winans, 198 U.S. 371 (1905); United States v. Oregon, 302 F.Supp. 899 (1969); United States v. Washington, 384 F. Supp. 312 (1974). Remarking on the State of Washington's recalcitrance in complying with the Boldt decision, a Ninth Circuit judge remarked that "[t]he state's extraordinary machinations in resisting the (1974) decree" were "except for some desegregation cases...the most concerted official and private efforts to frustrate a decree of a federal court witnessed in this century." Fay Cohen, Treaties on Trial, 100.

${ }^{5}$ Northwest Power Act, (g)(3) 2707-08.

${ }^{6}$ Oregon Department of Fish and Wildlife, Raymond R. Boyce, Project Leader, $A$ Comprehensive Plan for Rehabilitation of Anadromous Fish Stocks in the Umatilla River Basin, 1985.

${ }^{7}$ Northwest Power Planning Council, Columbia River Basin Fish and Wildlife Program, $\S 704(i)(1), 62$. 
${ }^{8}$ Michael Blumm, "Implementing the Parity Promise: An Evaluation of the Columbia Basin Fish and Wildlife Program," Environmental Law 14 (1984): 227.

${ }^{9}$ Letter from National Marine Fisheries Service to the Confederated Tribes of the Umatilla Indian Reservation, 1983, Confederated Tribes of the Umatilla Indian Reservation Umatilla restoration Project Papers (hereafter CTUIR Papers); Donald Sampson, personal interview, April 5, 1999; Cone, A Common Fate, 239.

${ }^{10}$ Sampson interview.

"Cone, A Common Fate, 237.

${ }^{12}$ Letter from Elwood H. Patawa, Chairman, Board of Trustees, Confederated Tribes of the Umatilla Indian Reservation, to Keith Colbo, Chairman, Fish and Wildlife Committee, Northwest Power Planning Council, February 11, 1983, CTUIR Papers.

${ }^{13}$ Bonneville Project Act of 1937, Public Law No. 75-329, ch. 720, § 7, 50 Statute 731-33.

${ }^{14}$ Donald Worster, Rivers of Empire: Water, Aridity, and the Growth of the American West, (New York: Oxford University Press) 1985, 262-266.

${ }^{15}$ Treaty on Cooperative Development of the Water Resources of the Columbia River Basin, Jan. 17, 1964, United States-Canada, U.S.T. 1555, in Cone and Ridlington, eds., The Northwest Salmon Crisis, 122-123.

${ }^{16}$ Richard White, The Organic Machine: The Remaking of the Columbia River, (New York: Hill and Wang) 1995.

${ }^{17}$ Lang, "River of Change," 358; Petersen, River of Life, Channel of Death, 149-163. The Corps also did not build a planned dam at Arlington on the mid-Columbia, but that was because the John Day dam was constructed high enough to render a second dam redundant.

${ }^{18}$ Robert C. Lothrop, "The Misplaced Role of Cost-Benefit Analysis in Columbia Basin Fishery Mitigation," Environmental Law 16 (Spring 1986): 553.

${ }^{19}$ Some have tried, specifically to help the preservation of salmon by showing the direct economic benefits of the fishery. See Glen Spain, "Statement of the Pacific Coast Federation of the Fisherman's Associations to the House Committee on Resources," Washington, DC, 9/20/95, reprinted in The 1996 Animal Law Conference: Legal Issues Concerning Animals of the Pacific Northwest, Portland, Northwestern School of Law, 1996.

${ }^{20}$ United States v. Winans, 198 U.S. 371 (1905); Puyallup Tribe v. Department of Game, 391 U.S. 392 (1968); United States v. Oregon, 302 F.Supp. 899 (1969); United States v. Washington, 384 F. Supp. 312 (1974); Washington et al. v. Washington State Commercial Passenger Vessel Association et al., 443 U.S. 658 (1979).

${ }^{21}$ Lothrop, "The Misplaced Role of Cost-Benefit Analysis," 532-534.

${ }^{22}$ Letter from National Marine Fisheries Service to the Confederated Tribes of the Umatilla Indian Reservation, 1983, CTUIR Papers. (Emphasis added.)

${ }^{23}$ William L. Lang, "River of Change," in The Northwest Salmon Crisis, ed. Joseph Cone and Sandy Ridlington, 352 .

${ }^{24}$ Michael C. Blumm, "Implementing the Parity Promise: An Evaluation of the Columbia Basin Fish and Wildlife Program." Environmental Law 14, (Winter, 1984), 277-358.

${ }^{25}$ P. Parenteau, Mitigation: Law and Policy, 1/6/79, cited in Lothrop, note 53.

${ }^{26}$ Lothrop, "The Misplaced Role of Cost-Benefit Analysis," 533.

${ }^{27}$ Ed Chaney, "The Last Salmon Ceremony: Implementing the Columbia River Basin Fish and Wildlife Program," Idaho Law Review 22 (1986), 563.

${ }^{28}$ Chaney, "The Last Salmon Ceremony," 562-563. (Emphasis added.)

${ }^{29}$ Northwest Power Act, § (h)(10)(A), 2710.

${ }^{30}$ Northwest Power Act, $\S(\mathrm{h})(11)(\mathrm{A})(\mathrm{ii}), 2711$.

${ }^{31}$ Bonneville Power Administration, "Fish and Wildlife Division," 1982.

${ }^{32}$ Ibid.

${ }^{33}$ Northwest Power Planning Council, Columbia River Basin Fish and Wildlife Program, (Portland, 1982). 
${ }^{34}$ Chaney, "The Last Salmon Ceremony," 571. Chaney suggests that there were two factions within BPA's fish and wildlife division, one pro-Umatilla, one anti-Umatilla. While this would explain some of Bonneville's bizarre behavior, I cannot find any specific corroborating evidence in the historical record.

${ }^{35}$ Chaney, "The Last Salmon Ceremony," 574.

${ }^{36}$ Ibid., 575.

${ }^{37}$ Letter from John Palensky, Director, Division of Fish and Wildlife, Bonneville Power Administration to Elwood Patawa, Board of Trustees, Confederated Tribes of the Umatilla Indian Reservation, 12/12/83; cited in Chaney, "The Last Salmon Ceremony," 578. (Emphasis added.)

${ }^{38}$ Chaney, "The Last Salmon Ceremony," 583-584.

${ }^{39}$ Ibid., 583.

${ }^{40}$ Donald Worster, Nature's Economy: A History of Ecological Ideas, (Cambridge: Cambridge University Press, 1994) 306-315.

${ }^{41}$ Oregon Department of Fish and Wildlife, Comprehensive Plan for Rehabilitation of Anadromous Fish Stocks in the Umatilla River Basin, (Portland: Bonneville Power Administration) 1985 .

${ }^{42}$ Chaney, "The Last Salmon Ceremony," 590.

${ }^{43}$ Agenda, "BPA-USBR Umatilla Basin Meeting," Portland, 11/21/85, CTUIR.

${ }^{44}$ Letter from John Palensky, Director, Division of Fish and Wildlife, Bonneville Power Administration, to Ed Chaney, January 7, 1986, CTUIR Papers.

${ }^{45}$ Ibid.

${ }^{46}$ Letter from John Palensky, Director, Division of Fish and Wildlife, Bonneville Power Administration, to Robert Saxvik, Chairman, Northwest Power Planning Council, 2/14/86, CTUIR Papers.

${ }^{47}$ Ibid.

${ }^{48}$ Letter from Edward Sheets, Executive Director, Northwest Power Planning Council, to Janet McClennan, Assistant Power Manager for Natural Resources and Public Services, Bonneville Power Administration, 5/2/86, CTUIR Papers.

${ }^{49}$ Ibid.; Internal NPPC memorandum, "Bonneville proposal on Umatilla project implementation," from Willa Nehlsen to Don Godard, Jan Carpenter, and Ron Eggers, 8/5/86, CTUIR Papers.

${ }^{50}$ T. Vogel, A Measured Approach to Umatilla River Basin Salmon and Steelhead Rehabilitation [no publishing location given, undated], 2, CTUIR Papers.

51 "Excerpts from Hearing on Fish and Wildlife Program Amendments: Transcript of Proceedings," Northwest Power Planning Council, October 8, 1986, 154-157, CTUIR Papers.

${ }^{52}$ Letter from Kai N. Lee, Councilmember, Northwest Power Planning Council, to Jan Carpenter, Director, Fish and Wildlife Division, Northwest Power Planning Council, 10/4/86, CTUIR Papers.

${ }^{53}$ Memorandum from Ed Chaney to Ken Hill, "Re: BPA v. the Umatilla River-The Continuing Saga," 11/19/86, p. 1, CTUIR Papers.

${ }^{54}$ Chaney, "The Last Salmon Ceremony."

${ }^{55}$ Letter form Ed Chaney, Director, Northwest Resource Information Center, Inc. to John Palensky, Director, Division of Fish and Wildlife, Bonneville Power Administration, 2/17/1984; in Chaney, "The Last Salmon Ceremony," 581, CTUIR Papers.

${ }^{56}$ Chaney, "The Last Salmon Ceremony," 593.

${ }^{57}$ Ibid., 599, 602.

${ }^{58}$ Ibid., 593, 606.

${ }^{59}$ Letter from Ken Hall, Chairman, Board of Trustees, Confederated Tribes of the Umatilla Indian Reservation, to James Jura, Administrator, Bonneville Power Administration, October 30, 1986, CTUIR Papers. 
${ }^{60}$ Memorandum from Ed Chaney, Umatilla Basin Project Coordinator for the Confederated Tribes of the Umatilla Indian Reservation, to Ken Hall, Chairman, Board of Trustees, Confederated Tribes of the Umatilla Indian Reservation, November 19, 1986, 1, CTUIR Papers.

${ }^{61}$ Anthony Netboy, The Columbia River Salmon and Steelhead Trout: Their Fight For Survival, 75; Charles F. Wilkinson, Crossing the Next Meridian: Land, Water, and the Future of the West (Covelo: Island Press, 1992), 196; Keith Petersen, River of Life, Channel of Death: Fish and Dams on the Lower Snake (Lewiston: Confluence Press, 1995); Pitzer, Grand Coulee: Harnessing a Dream, 223. There is no documentation that this statement was ever made, and the Corps denies it was said, but it has long since gone into the lore of the salmon crisis.

\section{Notes to Chapter IV}

' Paul Koberstein, "The Umatilla River Blues," October 16, 1991, The Oregonian, B01.

${ }^{2}$ Donald Worster, "The Warming of the West," in An Unsettled Country: Changing Landscapes of the American West, (Albuquerque: University of New Mexico Press) 1994, 97.

${ }^{3}$ U.S. Bureau of Reclamation, "Umatilla Basin Project, Oregon: Summary," Bureau of Reclamation, Boise, Idaho, October 1995, 18

${ }^{4}$ Winters $v$. United States, 28 S. Ct. 207, 207-08 (1908). The Court held that water rights were reserved by Indian tribes along with their reservations; Charles Wilkinson, "Harvesting the April Rivers," chap. in Crossing the Next Meridian: Land, Water, and the Future of the West (Covelo: Island Press, 1992), 267-269.

${ }^{5}$ Sampson interview.

${ }^{6}$ Winters $v$. United States, 212.

${ }^{7}$ Francis Paul Prucha, The Great Father: The United States Government and the American Indians (Lincoln: University of Nebraska Press), 1984, 893; Stephen L. Pevar, The Rights of Indians and Tribes (Carbondale: Southern Illinois University Press), 1992, 209-210; .

${ }^{8}$ Byers v. Wa-Wa-Ne, 169 Pacific Reporter 121, 1917; Sampson interview.

${ }^{9}$ Ibid., 127.

${ }^{10}$ Ibid.

"Ibid.

${ }^{12} 43$ U.S.C. Sec. $666(a)$.

${ }^{13}$ Pevar, 210.

${ }^{14}$ These figures vary wildly depending on the source. For $\$ 8$ million, see The Oregonian, "Umatilla River Blues," Paul Korbestn; for $\$ 50$ million, see Letter from Hadley Akins, Director, Umatilla Basin Project Steering Committee, to Senator Mark Hatfield, January 21, 1886.

${ }^{15}$ Wilkinson, Crossing the Next Meridian, 9-15; Burton, 65-66.

${ }^{16} \mathrm{Hal}$ Bernton, "Worlds Collide in Klamath Basin, the Sunday Oregonian, A1.

${ }^{17}$ Susan K. Driver, "Confederated Tribes of the Warm Springs Reservation Reach Historic Water Settlement Agreement," in Big River News: Northwest Water Law and Policy Project 4, no. 2, Winter 1998.

${ }^{18}$ Sampson Interview.

${ }^{19}$ Memorandum, Confederated Tribes of the Umatilla Indian Reservation, March 11, 1983, CTUIR Papers.

${ }^{20}$ Worster, Rivers of Empire, 130-131.

${ }^{21}$ Press Release, Confederated Tribes of the Umatilla Indian Reservation, Feb. 20, 1083, CTUIR Papers.

${ }^{22}$ Press Release, Confederated Tribes of the Umatilla Indian Reservation, February 25, 1983 , CTUIR Papers.

${ }^{23}$ Chaney to Akin, $11 / 1 / 82$, p. 2, CTUIR Papers.

${ }^{24}$ Letter from Ed Chaney to Hadley Akin, November 1, 1982, CTUIR Papers; Memorandum from Ed Chaney to Cathy Wilson, November 1, 1982, CTUIR Papers. 
${ }^{25}$ Letter from Kendall L. Hill for Elwood H. Patawa, Chairman, Board of Trustees, Confederated Tribes of the Umatilla Indian Reservation, to the Oregon Water Resources Department, August 10, 1983, CTUIR Papers.

${ }^{26}$ Catherine Wilson, "Summary, Umatilla Basin Project Steering Committee Meeting," July 11, 1984, CTUIR Papers.

${ }^{27}$ Id.; Cone, $A$ Common Fate, 230.

${ }^{28}$ Letter from the Umatilla Basin Project Steering Committee to Honorable Mark Hatfield, January 21, 1986, CTUIR Papers.

${ }^{29}$ U.S. Bureau of Reclamation, "Umatilla Basin Project, Oregon: Status Report," Bureau of Reclamation (Boise, Idaho), March, 1985.

${ }^{30}$ Ibid.

${ }^{31}$ U.S. Bureau of Reclamation, "Umatilla Basin Project, Oregon: Sumary," Bureau of Reclamation, (Boise): October 1985.

${ }^{32}$ Letter from Ed Chaney, Umatilla Basin Project Coordinator, to Dave Duncan, Bureau of Reclamation, November 19, 1986, CTUIR Papers.

${ }^{33}$ Cone, A Common Fate, 238-239; Memorandum from Ed Chaney to the Umatilla Project Steering Committee, January 14, 1986; Letter from Donald W. Godard, Member Northwest Power Planning Council, to the Honorable Les AuCoin, April 18, 1986, CTUIR Papers; Letter from Donald W. Godard, Member Northwest Power Planning Council, to the Honorable Mark Hatfield, April 18, 1986, CTUIR Papers.

${ }^{34}$ Dick Cockle, "Return of the Salmon Runs Means Much to Indians," the Oregonian, B10, quoting Representative Les AuCoin ("right for the environment") in 1991, and Gov. Neil Goldschmidt ("morally essential") in 1988.

${ }^{35}$ Letter from Ed Chaney, to Umatilla Project Steering Committee, January 14, 1986, CTUIR Papers.

${ }^{36}$ Letter from Janet McLennan, Assistant Power Manager for Natural Resources and Public Services Office of Power and Resources Management, Bonneville Power Administration, to John W. Keys III, Acting Regional Director, Bureau of Reclamation, June 18, 1986, CTUIR Papers.

${ }^{37}$ Letter from John W. Keys, III, Regional Director, U.S. Bureau of Reclamation, to Ron

Eggers, Biological Services Manager, Northwest Power Planning Council, September 12, 1986, CTUIR Papers.

${ }^{38}$ Letter from Al Wright, Executive Director, Pacific Northwest Utilities Conference

Committee, to Mark O. Hatfield, February 25, 1988, CTUIR Papers.

${ }^{39}$ Boyce, A Comprehensive Plan for Rehabilitation of Anadromous Fish Stocks in the Umatilla River Basin, 1985.

${ }^{40}$ Letter from Pacific Northwest Utilities Conference Committee to John Palensky, Director, Division of Fish and Wildlife, Bonneville Power Administration, September 13, 1985, CTUIR Papers.

${ }^{41}$ Letter from Pamela Barrow for Al Write, Executive Director, Pacific Northwest Utilities

Conference Committee, to John W. Keys, III, Regional Director, Pacific Northwest Region, U.S.

Bureau of Reclamation, October 30, 1986, CTUIR Papers.

${ }^{42}$ Northwest Power Act, (h)(10)(A), 2710.

${ }^{43}$ Letter from Pamela Barrow for Al Wright, Executive Director, Pacific Northwest Utilities Conference Committee, to Senator Mark Hatfield, February 25, 1988, CTUIR Papers; Northwest Power Act, § 4(h)(10)(A).

44 "PNUCC Report: Bill Requires BPA to Provide Free Power for Fish Flows," March 4, 1988, CTUIR Papers.

${ }^{45}$ Al Write, PNUCC, "Consultation Meeting Notes \& Transcript, Umatilla River Flow Enhancement Rulemaking," Pendleton, Oregon, August 17, 1988, 26, CTUIR Papers.

${ }^{46}$ Memorandum from Ed Chaney, Umatilla Basin Project Coordinator, to Ken Hall, Chairman, Board of Trustees, Confederated Tribes of the Umatilla Indian Reservation, November 19, 1986, CTUIR Papers. 
${ }^{47}$ Letter from Ed Chaney, Umatilla Basin Project Coordinator, to Ken Hall, Chairman, Board of Trustees of the Confederated Tribes of the Umatilla Indian Reservation, September 16, 1986, CTUIR Papers.

${ }^{48} 100^{\text {th }}$ Congress, $2 \mathrm{~d}$ Session, "Report to accompany S. $1613, " \S 4$.

${ }^{49}$ Sampson Interview.

${ }^{50}$ Paul Koberstein, "The Umatilla River Blues," the Oregonian, October 6, 1991, B1.

${ }^{51}$ Richard Cockle, "Panel Restores Federal Money For Fish Project," May 18, 1991, E7; letter from Elwood Patawa, Chairman, Board of Trustees, Confederated Tribes of the Umatilla Indian Reservation, to Senator Mark Hatfield, February 9, 1987, CTUIR Papers.

${ }^{52}$ Letter from Charles T. Simmons, Chairman, WaterWatch of Oregon, to Senator Mark Hatfield, September 3, 1991, CTUIR Papers.

${ }^{53}$ Bill Kloos to William F. Young, Director, Oregon Water Resources Department, September 27, 1991, CTUIR Papers.

${ }^{54}$ Letter from William H. Young, Director, Oregon Water Resources Department, to Larry Vinsonhaler, Regional Planning Officer, Bureau of Reclamation, January 28, 1986 (stating OWRD was aware that water "saved" by conservation was being by the Westland Irrigation District, even as it applied for expansion), CTUIR Papers; Interoffice Memo from the Oregon Water Resources Department, to Bureau of Reclamation, January 28, 1986, CTUIR Papers; "Petition of WaterWatch of Oregon, Inc. to amend the Umatilla Basin Program," September 27, 1991, CTUIR Papers.

${ }^{55}$ Letter from Charles T. Simmons to John Keys, Bureau of Reclamation, September 3, 1991, CTUIR Papers.

${ }^{56}$ Id.

${ }^{57}$ U.S.C. Public Law 100-557, October 28, 1988; U.S. Bureau of Reclamation, "Review of Umatilla Project Operations, Umatilla Basin Project, Oregon," November, 1989.

${ }^{58}$ Paul Koberstein, "The Umatilla River Blues," the Oregonian, October 6, 1991, B1.

59 "Letter to the Editor," John W. Keys, Regional Director U.S. Bureau of Reclamation Boise, Idaho, the Oregonian, October 29, 1991, CTUIR Papers.

${ }^{60}$ Letter from Charles T. Simmons, Chairman, WaterWatch of Oregon, to John Keys, U.S.

Bureau of Reclamation, November 12, 1991, CTUIR Papers.

${ }^{61}$ Letter from Bill Kloos to Oregon Water Resources Commission, November 12, 1991, CTUIR Papers.

${ }^{62}$ Oregon Water Resources Department, "Notice of Public Meeting on Enforcement Schedule for the Umatilla River and McKay Creek," November 25, 1991, CTUIR Papers.

${ }^{63}$ Paul Koberstein, "Farmers Denounce Umatilla River Plan," the Oregonian, December 4, 1991.

${ }^{64}$ Memorandum from Ed Chaney to Antone Minthorn, Dan Hester, and Gary James, November 11, 1989, 1, CTUIR Papers.

${ }^{65}$ Id.

${ }^{66}$ Id., 2.

${ }^{67}$ Paul Koberstein, "State Acts Against Illegal Water Use in Umatilla Basin," the Oregonian, December 21, 1991

${ }^{68}$ Memorandum from Antone Minthorn and Becky Hiers, to John Keys, Frank Gunner, Bob O'Rourke, Bill Porfily, Bill Kloos, Anna Perrault, Tom Simmons, John Borden, Mike Ladd, Jill Zarnowitz Jim Phelps, Jim Myron, Laura Schroedor, Jay Marcotte, Don Armstrong, Andy Kerr, Chapin Clark, Elaine Hallmark, May 19, 1992, CTUIR Papers.

\section{Notes to Chapter V}

'Sampson, "Who Runs the Reservoirs?" 691.

${ }^{2}$ Sampson Interview.

${ }^{3}$ NPPC, Columbia River Basin Fish and Wildlife Program, 1984, 6. 
${ }^{4}$ Douglas W. Dompier, "Commentary," in Cone and Ridlington, The Northwest Salmon Crisis, 203-205; Joseph Cone, A Common Fate, 72-73.

${ }^{5}$ For example, see Fay Cohen, Treaties on Trial for some of the conflict between the State of Washington and Indian tribes there.

${ }^{6}$ Boyce, A Comprehensive Plan for Rehabilitation of Anadromous Fish Stocks in the Umatilla River Basin, 1985.

${ }^{7}$ Letter from Don Chapman to Tom Giese, PNUCC, July 11, 1988.

${ }^{8}$ Paul Koberstein, "The Umatilla River Blues," B4.

${ }^{9}$ Id.

${ }^{10}$ Barry Lopez, “A Voice,” in About This Life (New York: Alfred A. Knopf, 1998), 13. 


\section{TERMINAL REFERENCES}

$m m m$

\section{Books}

American Friends Service Committee. Uncommon Controversy: Fishing Rights of the Muckleshoot, Puyallup, and Nisqually Indians. Seattle: University of Washington Press, 1970.

Bunting, Robert. The Pacific Raincoast: Environment and Culture in an American Eden, 1778-1900. Lawrence: University of Kansas Press, 1997.

Burton, Lloyd. American Indian Water Rights and the Limits of the Law. Lawrence: University of Kansas Press, 1991.

Canby, Jr. William C. American Indian Law in a Nutshell. 2d. edition. St. Paul: West Publishing Company, 1988.

Cohen, Fay G. Treaties on Trial: The Continuing Controversy over Northwest Indian Fishing Rights. Seattle: University of Washington Press, 1986.

Cone, Joseph. A Common Fate: Endangered Salmon and the People of the Pacific Northwest. Corvallis: Oregon State University Press, 1996.

Cone, Joseph, and Sandy Ridlington. The Northwest Salmon Crisis: A Documentary History. Corvallis: Oregon State University Press, 1996.

Deloria, Jr., Vine. Indian Education in America. Boulder: American Indian Science and Engineering Society, 1991.

Dietrich, William. Northwest Passage: The Great Columbia River. New York: Simon and Schuster, 1995.

Fox, Stephen. The American Conservation Movement: John Muir and His Legacy. Madison: University of Wisconsin Press, 1981.

Hunn, Eugene S. with James Selam and Family. Nch'i-Wána, "The Big River": MidColumbia Indians and Their Land. Seattle: University of Washington Press, 1990. 
Kappler, Charles J. Indian Affairs: Laws and Treaties, Volume II, Treaties. Washington: U.S. Government Printing Office, 1904.

Langston, Nancy. Forest Dreams, Forest Nightmares: The Paradox of Old Growth in the Inland West. Seattle: University of Washington Press, 1995.

Lee, Kai N. Compass and Gyroscope: Integrating Science and Politics for the Environment. Covelo: Island Press, 1993.

Leopold, Aldo. A Sand County Almanac. New York: Oxford University Press, 1949.

Lopez, Barry. About This Life: Journeys on the Edge of Memory. New York: Alfred A. Knopf, 1998.

. River Notes: The Dance of Herons. New York: Avon Books, 1979.

McGuire, Thomas R., William B. Lord, and Mary G. Wallace, eds. Indian Water and the New West. Tucson: University of Arizona Press, 1993. [Chap. in Davis Yardas, "Water Transfers, Paper Rights, and the Truckee-Carson Settlement", 195-205.]

Merchant, Carolyn. The Death of Nature: Women, Ecology and the Scientific Revolution. San Francisco: Harper Collins, 1980.

Nash, Roderick Frazier. The Rights of Nature: A History of Environmental Ethics. Madison: University of Wisconsin Press, 1989.

.Wilderness and the American Mind. New Haven: Yale University Press, 1977.

Netboy, Anthony. The Columbia River Salmon and Steelhead Trout:: Their Fight For Survival. Seattle: University of Washington Press, 1980.

Petersen, Keith. River of Life, Channel of Death: Fish and Dams on the Lower Snake. Lewiston: Confluence Press, 1995.

Pevar, Stephen L. The Rights of Indians and Tribes: The Basic ACLU Guide to Indian and Tribal Rights. Carbondale: Southern Illinois University Press, 1992.

Pitzer, Paul. Grand Coulee: Harnessing a Dream. Pullman: Washington State 
University Press, 1994.

Prucha, Francis Paul. The Great Father: The United States Government and the American Indians. Lincoln: University of Nebraska Press, 1984.

Richards, Kent D. Isaac I. Stevens: Young Man in a Hurry. Provo: Brigham Young University Press, 1979.

White, Richard. The Organic Machine: The Remaking of the Columbia River. New York: Hill and Wang, 1995.

Smith, Courtland L. Salmon Fishers of the Columbia. Corvallis: Oregon State University Press, 1979.

Ulrich, Roberta. Empty Nets: Indians, Dams, and the Columbia River. Corvallis: University of Oregon Press, 1999.

Wilkinson, Charles F. Crossing the Next Meridian: Land, Water, and the Future of the West. Covelo: Island Press, 1992.

Willingham, William F. Army Engineers and the Development of Oregon: A History of the Portland Distrist of the U.S. Army Corps of Engineers. Washington, D.C.: Government Printing Office, 1983.

Woody, Elizabeth. Luminaries of the Humble. Tucson: University of Arizona Press, 1994.

. Seven Hands, Seven Hearts. Portland: The Eighth Mountain Press, 1994.

Worster, Donald. Rivers of Empire: Water, Aridity, and the Growth of the American West. New York: Oxford University Press, 1985.

. Nature's Economy: A History of Ecological Ideas. Cambridge: Cambridge University Press, 1977.

. An Unsettled Country: Changing Landscapes of the American West. Albuquerque: University of New Mexico Press, 1994. 


\section{Articles}

Barsh, Russel L. "Backfire From Boldt: The Judicial Transformation of Coast Salish "Proprietary Fisheries into a Commons." Western Legal History: The Journal of the Ninth Judicial Circuit Historical Society 4, (Winter/Spring 1991): 85102.

Bodi, F. Lorraine and Eric Erdheim. "Swimming Upstream: FERC's Failure to Protect Anadromous Fish." Ecology Law Quarterly 13, (1986): 7-37.

Booth, Annie L. and Harvey M. Jacobs. "Ties That Bind: Native American Beliefs as a Foundation for Environmental Consciousness." Environmental Ethics 12, (Spring, 1990): 27-43.

Blumm, Michael C. "Hydropower vs. Salmon: The Struggle of the Pacific Northwest's Anadromous Fish Resources for a Peaceful Coexistence with the Federal Columbia River Power System." Environmental Law 11 (1981): 211.

Blumm, Michael C. "Implementing the Parity Promise: An Evaluation of the Columbia Basin Fish and Wildlife Program." Environmental Law 14 (Winter, 1984): 277-358.

Blumm, Michael C. "Reexamining the Parity Promise: More Challenges Than Successes to the Implementation of the Columbia Basin Fish and Wildlife Program." Environmental Law 16 (1986): 431.

Blumm, Michael C. "Salmon Law and Policy in 1995: A Brief Overview." Environmental Law 26, (Summer 1996): 651-655.

Blumm, Michael C. "Unconventional Waters" The Quiet Revolution in Federal and Tribal Minimum Streamflows." Ecology Law Quarterly 19 (1992): 445-480.

Blumm, Michael C. and Johnson. "Promising a Process for Parity: The Pacific Northwest Electric Power Planning and Conservation Act and Anadromous Fish Protection." Environmental Law 11 (1981): 497.

Blumm, Michael C. and Michael Cadigan. "The Indian Court of Appeals: A Modest Proposal to Eliminate Supreme Court Jurisdiction over Indian Cases." Arkansas Law Review 46, (1993): 203-235.

Callicott, J. Baird. "The Case Against Moral Pluralism." Environmental Ethics 12 
(Summer, 1990): 99-124.

. "Rolston on Intrinsic Value: A Deconstruction." Environmental Ethics 14 (Summer, 1992): 129-143.

. "Non-Anthropocentric Value Theory and Environmental Ethics." American Philosophical Quarterly 21 (October, 1984): 299-309.

Chaney, Ed. "The Last Salmon Ceremony: Implementing the Columbia River Basin Fish and Wildlife Program." Idaho Law Review 22 (1986): .

Chaney, Ed and L. Edward Perry, Columbia Basin Salmon and Steelhead Analysis: Summary Report. Portland: Pacific Northwest Regional Commission, 1976.

Lothrop, Robert C. "The Misplaced Role of Cost-Benefit Analysis in Columbia Basin Fishery Mitigation." Environmental Law 16, (Spring 1986): 517-554.

McGinnis, Michael V. "On the Verge of Collapse: The Columbia River System, Wild Salmon and the Northwest Power Planning Council." Natural Resources Journal 35, (Winter 1995): 63-92.

Miller, Robert. "Speaking with Forked Tongues: Indian Treaties, Salmon, and the Endangered Species Act." Oregon Law Review 70, (Fall 1991): 543-584.

Phillips, Jennifer L., Jill Ory, and André Talbot. "Anadromous Salmonid Recovery in the Umatilla River Basin, Oregon: A Case Study." Journal of the American Water Resources Association 36 (December 2000): 1287-1308.

Plumwood, Val. "Ethics and Instrumentalism: A Response to Janna Thompson." Environmental Ethics 13 (Summer 1991): 139-149.

Raymond, Howard L. "Effects of Dams and Impoundments on Migrations of Juvenile Chinook Salmon and Steelhead from the Snake River, 1966 to 1975." Transactions of the American Fisheries Society 108 (November 1979): 505-529.

Richards, Kent D. "Historical Antecedents to the Boldt Decision." Western Legal History: The Journal or the Ninth Judicial Circuit Historical Society 4 (Winter/Spring 1991): 69-84.

Routley, Richard and Val Routley. "Human Chauvinism and Environmental Ethics." 
Environmental Philosophy, ed. Don Mannison, Michael McRobbie, and Richard Routley, 96-189. Canberra: Australian National University, 1980.

Sampson, Don. "One Tribe's Perspective on 'Who Runs the Reservoirs."” Environmental Law 26 (Summer 1996): 681-691.

Schaulk, Randall. "Estimating Salmon and Steelhead Usage in the Columbia Basin Before 1850: The Anthropological Perspective." Northwest Environmental Journal 2 (1986): 2-23.

Spain, Glen H. "Salmon: A Crisis in Culture." Illahee 10 (Winter 1994): 284-291.

Thompson, Janna. "A Refutation of Environmental Ethics." Environmental Ethics 12 (Summer 1990): 147-160.

Volkman, John M., and Willis E. McConnaha. "Through a Glass Darkly: Columbia River Salmon, the Endangered Species Act, and Adaptive Management." Environmental Law 23 (1993): 1249-1272.

White, Ray J., James R. Karr, and Willa Nehlsen. "Better Roles for Fish Stocking in Aquatic Resource Management." American Fisheries Society Symposium 15 (1995): 527-547.

Wilkinson, Charles F. and D.K. Conner. "The Law of the Pacific Salmon Fishery." University of Kansas Law Review 32 (1983): 17-210.

\section{Government and Tribal Documents}

Bonneville Power Administration, Office of Power and Resources Management. Environmental Assessment: Umatilla Fish Hatchery. Portland: Bonneville Power Administration, 1987.

Umatilla Restoration Project Papers. Fisheries Department, Department of Natural Resources, Confederated Tribes of the Umatilla Indian Reservation, Mission, Oregon.

Galindo, Ed, and Ben Rinehart. Indian Summer IV: Student Streamside Incubation Project, 1998. Fort Hall: Shoshone-Bannock Fisheries Department, 1998.

Independent Scientific Group. Return to the River: Restoration of Salmonid Fishes to 
the Columbia River Ecosystem. Portland: Northwest Power Planning Council, 1996.

Kreag, Rebecca A. Umatilla River Return Flow Analysis During 1985 and 1986.

Salem: State of Oregon Water Resources Division, 1991.

Northwest Power Planning Council. Columbia River Basin Fish and Wildlife Program. Portland: the Northwest Power Planning Council, 1984.

Oregon Department of Fish and Wildlife, Raymond R. Boyce, Project Leader. Final Report: A Comprehensive Plan for Rehabilitation of Anadromous Fish Stocks in the Umatilla River Basin. Portland: Bonneville Power Administration, 1985.

Rich, Willis H. A Survey of the Columbia River and its Tributaries with Special Reference to the Management of its Fishery Resources. Part 5, No. 38. Washington, D.C.: U.S. Fish and Wildlife Service, 1948.

Schoning, R.W., T.R. Merrel, Jr.,, and D.R. Johnson. The Indian Dip Net Fishery at Celilo Falls on the Columbia River. Portland: Oregon Fish Commission, 1951.

Thompson, Robert N. and James B. Haas. Environmental Survey Pertaining to Salmon and Steelhead in Certain River of Eastern Oregon and the Willamette River and its Tributaries. Part I. Survey Reports of Eastern Oregon Rivers. Clackamas: Fish Commission of Oregon, June 1960.

United States Bureau of Reclamation. Bureau of Reclamation Feasibilities and Authorizations: A Compilation of Findings of Feasibilities and Authorizations for Bureau of Reclamation Projects of the Department of the Interior. Washington, D.C.: U.S. Government Printing Office, 1957.

United States Department of Interior. The Columbia River: A Comprehensive Department Report on the Development of the Water Resources of the Columbia River Basin for Review Prior to Submission to the Congress. Washington, D.C.: U.S. Government Printing Office, 1947.

United States Commission of Fish and Fisheries. Report of the Commissioner for 1883. Washington, D.C.: Government Printing Office, 1885 


\section{Dissertations \& Theses}

McKern, J.C. "Steelhead Trout Otholiths." MA thesis, Oregon State University, 1971.

Rosenberg, John P. "The Angler as Environmentalist: Oregon Trout and the Fight to Save the Wild Salmon of the Columbia River." MA. thesis, Portland State University, 1991.

Taylor, Joseph E. III. "Making Salmon: Economy, Culture, and Science in the Oregon Fisheries, Precontact to 1960." Ph.D. diss., University of Washington, 1996.

Ulrich, Roberta. "Justice Delayed: A Sixty Year Battle for Indian Fishing Sites." MA. thesis, Portland: Portland State University, 1996.

\section{Other Sources}

Sampson, Donald A. Interview with author. Portland, Oregon, 1996. 